\title{
Endemic species of Christmas Island, Indian Ocean
}

\author{
D.J. James ${ }^{1}$, P.T. Green², W.F. Humphreys ${ }^{3,4}$ and J.C.Z. Woinarski ${ }^{5}$ \\ 173 Pozieres Ave, Milperra, New South Wales 2214, Australia. \\ 2 Department of Ecology, Environment and Evolution, La Trobe University, Melbourne, \\ Victoria 3083, Australia. \\ ${ }^{3}$ Western Australian Museum, Locked Bag 49, Welshpool DC, Western Australia 6986, Australia. \\ ${ }^{4}$ School of Biological Sciences, The University of Western Australia, 35 Stirling Highway, Crawley, \\ Western Australia 6009, Australia. \\ ${ }^{5}$ NESP Threatened Species Recovery Hub, Charles Darwin University, Casuarina, \\ Northern Territory 0909, Australia, \\ Corresponding author: john.woinarski@cdu.edu.au
}

\begin{abstract}
Many oceanic islands have high levels of endemism, but also high rates of extinction, such that island species constitute a markedly disproportionate share of the world's extinctions. One important foundation for the conservation of biodiversity on islands is an inventory of endemic species. In the absence of a comprehensive inventory, conservation effort often defaults to a focus on the better-known and more conspicuous species (typically mammals and birds). Although this component of island biota often needs such conservation attention, such focus may mean that less conspicuous endemic species (especially invertebrates) are neglected and suffer high rates of loss.
\end{abstract}

In this paper, we review the available literature and online resources to compile a list of endemic species that is as comprehensive as possible for the $137 \mathrm{~km}^{2}$ oceanic Christmas Island, an Australian territory in the north-eastern Indian Ocean. This objective is helped by impressive biodiversity inventories made within a decade of the island's first human settlement (1888) that provide a reasonable baseline from which to measure the changes associated with the island's colonisation and development. However, there are some notable challenges in compiling this inventory: the spate of surveys that preceded and immediately followed the island's settlement has not been matched subsequently; many groups have not been sampled, or sampled only superficially; the taxonomic fate of some of the species initially described from the island is opaque; some endemic taxa are of contested taxonomic rank; and demonstrating endemicity is difficult given that there has been relatively little sampling in the nearest lands (Java and nearby islands, about $350 \mathrm{~km}$ distant from Christmas Island).

We conclude that at least 253 species are endemic to Christmas Island (including 17 vascular plants, 27 molluscs, 15 crustaceans, 150 insects and 21 vertebrates). There has been a high rate of extinction of the island's endemic mammal and reptile faunas, with at least six of the 10 endemic species now extinct or extinct in the wild. In the last decade, an endemic mammal and an endemic reptile species became extinct, and two endemic reptile species became extinct in the wild. Given the array of introduced species and other environmental disruptions now present on the island, it is highly plausible that many endemic species in less conspicuous or charismatic groups are now imperilled or already extinct; indeed, we conclude that more than 50 endemic species have not been reported for $>100$ years. Hence, the recognised number of extinct and of threatened species on this island is likely to be severely under-estimated. Although most of the endemic vertebrate species are listed as threatened (or extinct), only one of the c. 200 endemic invertebrate species is formally listed as threatened. This lack of listing is likely to severely understate the conservation plight of many species, and most would merit recognition as threatened.

KEYWORDS: conservation, endemism, extinction, fungi, invertebrates, island, lichen, plants, vertebrates 


\section{INTRODUCTION}

Oceanic islands support a disproportionately large share of the world's biodiversity relative to their total area (Kier et al. 2009; Tershy et al. 2015). However, island-endemic species also make up a disproportionate share of the world's modern extinctions, including the majority of recent extinctions in many taxonomic groups (Blackburn et al. 2004; Brooke et al. 2007; Sax and Gaines, 2008; Loehle and Eschenbach, 2012; Tershy et al. 2015; Doherty et al. 2016; McCreless et al. 2016; Woinarski et al. 2018). Hence, oceanic islands are a global priority for conservation attention.

Conservation management for any island is likely to be most effective and appropriately directed if it rests upon a robust knowledge base of the island's biodiversity attributes, such as the number and identity of its endemic species; and that its most imperilled species are recognised as such. Where such information is lacking or limited, there may be a high risk of species declining or going extinct before managers are aware of the species or aware of the need for remedial management action (Régnier et al. 2009; Régnier et al. 2015a; Régnier et al. 2015b). Such risks may be particularly severe for endemic species that are relatively inconspicuous and uncharismatic and those in relatively poorly-known taxonomic groups, such as most invertebrates (DinizFilho et al. 2010; Diniz-Filho et al. 2013): in contrast, island birds and mammals are generally well-known and the focus of most conservation attention.

Here we consider the biodiversity of the $137 \mathrm{~km}^{2}$ Christmas Island, an Australian external territory in the tropical eastern Indian Ocean, and its conservation prioritisation. There is a marked taxonomic bias in the global and national (Australian, under the Environment Protection and Biodiversity Conservation Act) listing of threatened species (Walsh et al. 2012), which is particularly pronounced in the case of Christmas Island. Of its 14 endemic terrestrial vertebrate species, twelve are listed as threatened or extinct (Table 1), and a further five endemic subspecies of terrestrial vertebrates are also listed as threatened at the national level. For plants, one of the island's 16 endemic species is listed as threatened, along with one endemic variety and two local populations of plant species with much more widespread distributions. In contrast, only one of Christmas Island's c. 200 endemic invertebrate species is listed as threatened globally and none are listed nationally. In part, this disparity reflects contrasts in the amount of knowledge available for different taxonomic groups, but it is also a consequence of a pervasive tendency to highlight the conservation concerns of more charismatic taxonomic groups at the expense of those with less public appeal (Cardoso et al. 2011a; Cardoso et al. 2011b; Walsh et al. 2012). In the case of Christmas Island biodiversity, listing as threatened under Australian legislation provides some notable conservation benefits: listed species tend to be regularly monitored, such that information on population trends is routinely available; the potential impacts upon them of proposed developments must be considered through legislated environmental impact assessment processes; recognised threats to them are the subject of management investment and control; and they are explicitly considered in spatial land-use planning exercises (Butz 2004; Hill 2004a; Hill 2004b; Schulz 2004; Schulz and Lumsden 2004; Cogger 2006). In contrast, species that may be equally imperilled but are not formally listed as threatened are often neglected, compounding a lack of knowledge that will constrain their likelihood of being listed as threatened and perpetuating a lack of conservation attention.

We aim to provide an inventory of species endemic to Christmas Island, as a basis for more comprehensive consideration of its biodiversity conservation values and needs. Such an inventory is of interest and importance for several reasons. First, and unusually, a substantial (albeit not exhaustive) inventory of the plants and animals of the island was compiled at about the time of the island's initial settlement, from the late 1880s (Boulenger 1887, 1889; Butler 1887, 1889; Dendy 1887; Pocock 1887, 1900; Sharpe 1887, 1900; Thomas 1887, 1889; Waterhouse 1887; Gahan 1889; Lister 1889; Smith 1889; Ridley 1891, 1906a,b; Waterhouse et al. 1900). Part of the explicit purpose of this early collection work was to provide an exemplary baseline against which changes in the island's biota (due to settlement and human influence) could subsequently be assessed (Andrews 1900c; Andrews 1909): 'It has not hitherto been possible to watch carefully the immediate effects produced by the immigration of civilized man - and the animals and plants which follow in his wake - upon the physical conditions and upon the indigenous fauna and flora of an isolated oceanic island. I hope to arrange that this shall be done in the case of Christmas Island' (Murray 1900). To some extent, this current paper facilitates some such assessment of the post-settlement fate of the island's endemic biota. Regrettably, calamity befell the next major collection, by Carl Gibson-Hill collected over a 2-year period from 1938-40: 'the greater part of the material obtained, covering the majority of the insect groups, was destroyed, unidentified, when the Kuala Lumpur Museum was bombed in 1945' (Gibson-Hill 1949b).

Second, from the time of the earliest biological sampling, the distinctiveness and endemicity of the island's biota was recognised. For example, the first visiting naturalist, J.J. Lister in 1887, reported that 'the most striking factor is the peculiarity of the fauna' (Lister 1889).

Third, the island has a highly unusual ecological context, largely determined by extremely high densities of a single invertebrate species, the red crab Gecarcoidea natalis (O'Dowd and Lake 1991; Green 1997; Green et al. 1997, 1999).

However, since the 1980s, the island's ecology has been subverted through 'invasional meltdown' (Green et al. 2001, 2011) due to the extensive establishment of supercolonies of the invasive yellow crazy ant Anoplolepis gracilipes, which have encompassed up to 
$25-30 \%$ of the island at times (Abbott 2006). There have been subsequent episodes of control with broad-scale application of insecticide followed by rebounds in colony extent (Green and O'Dowd 2009). Such disruption by the yellow crazy ants may be expected to have caused appreciable detriment to many endemic species. In response to the threat posed by crazy ants, managers implemented broad-scale baiting with the insecticide Fipronil. This has had serious non-target impacts elsewhere (Peveling et al. 2003; Gibbons et al. 2015; Van der Sluijs et al. 2015). However, baiting on Christmas Island has been implemented strategically with stringent and substantial measures to mitigate non-target impacts customised for the local conditions (e.g. see EPBC Act Referral Notices and Decisions 2002/722, 2009/5016 and $2012 / 6438$ covering the three aerial baiting operations in 2002, 2009 and 2012 respectively; http://epbcnotices. environment.gov.au/referralslist/). Three targeted studies (Weeks and McColl 2011; Weeks 2013; Stork et al. 2014) found no substantial evidence of non-target impacts on invertebrates, although they did not assess impacts on most endemic invertebrates specifically, at least in part because there was no comprehensive listing of these then available.

Many other plant and animal species - including invasive species known to have caused declines or extinctions in a wide range of island-endemic species elsewhere (e.g. black rat Rattus rattus, house cat Felis catus, giant centipede Scolopendra subspinipes, wolf snake Lycodon capucinus, giant African land snail Achaetina fulica) (Amori and Clout 2003; Doherty et al. 2016) - have also been introduced, deliberately or inadvertently, to the island and many of these are likely to have had detrimental impacts on at least some Christmas Island endemic species. Furthermore, since its settlement, the island has had an almost continuous history of phosphate mining (with about $25 \%$ of the island's original vegetation cleared for mining), and mining operations continue. Frequent proposals to extend mining operations require ongoing assessments of the likely impact upon biodiversity (particularly listed threatened species) from potential further forest clearing and mining operations (Frydenberg 2018). To properly assess the potential immediate and cumulative impacts of such proposed habitat loss it is necessary to be as explicit as possible about all the biodiversity assets at risk, and their status and their locations. Mining and other developments have also affected marine environments (such as damage to coral reefs for shipping infrastructure and from ships, spills of phosphate into marine environments, urban storm water run-off and oil spills), but these impacts are generally little documented (Hobbs et al. 2014a).

As a consequence of these detrimental factors, there has been a very high rate of loss of endemic vertebrates, including the extinction of at least three and probably four of the island's five endemic mammal species (Wyatt et al. 2008; Woinarski et al. 2017) and the recent (since 2009) extinction (or extinction in the wild) of three of its four endemic lizard species (Smith et al. 2012; Andrew et al.
2018). This gives reasonable grounds for concern that endemic species in less well-known groups might have become extinct, or are now highly imperilled, with such loss and decline going unnoticed.

The primary objective of this study is to compile a list of species endemic to Christmas Island. This is not a straightforward exercise, for several reasons. First, there is no comprehensive list of species that have been recorded from the island, from which endemic, native but non-endemic, and introduced species can readily be categorised: an exemplary case where this has been done is for invertebrates of Lord Howe Island (Cassis et al. 2003). The lack of such an inventory for Christmas Island also renders it difficult to compare proportional levels of endemicity among different taxonomic groups. Second, although some species have been recorded only from Christmas Island, it remains possible that some also exist in less well-sampled areas in the nearest land masses (e.g. Java, at c. $350 \mathrm{~km}$ distant) or more distantly. It is therefore possible that an inventory of species currently known only from Christmas Island may over-estimate the real extent of endemicity, but this is a general qualification in many such biogeographical analyses (Whittaker et al. 2008). Third, taxonomic boundaries are poorly resolved for many Christmas Island taxa. Highly conservative (mostly historical) taxonomy has seemingly treated several taxa as subspecies of more widely-ranging species rather than endemic species (James and McAllan 2014). In general, where such Christmas Island taxa of contested or indeterminate rank have been scrutinised using modern genetic or other systematic approaches, they have been shown to be valid species (Norman et al. 1998; Ng and Davie 2012; Orchard 2012; Eldridge et al. 2014; Rheindt et al. 2017). However, there is at least one contrary case where presumed endemic species have been shown to be not specifically distinct (Ohlsen et al. 2015). Fourth, many Christmas Island species have been recorded only in samples taken around the beginning of the twentieth century, and for some of these species there has been little subsequent taxonomic appraisal, so it is challenging to determine whether these described species remain valid, or whether taxa then considered to be referrable to more wide-ranging species may in fact be endemic. Fifth, although there have been some notable surveys of Christmas Island for many taxonomic groups, there are many groups that are unsampled or little sampled: this is likely to cause a potentially marked under-estimation in our tally of endemic species. Sixth, there has been some confusion in the literature relating to endemic species on this island, with attribution of some of its endemic species to a once-similarly named island (now Kiritimati), in the republic of Kiribati in the Pacific (Alcover et al. 1998). Given these caveats and constraints, we recognise that the list of endemic species developed here is an interim compilation, and we would expect and hope that it will be modified with ongoing research.

Endemicity is also a somewhat nuanced concept. We include here as endemic: (i) some species that breed only on Christmas Island, but disperse widely 
elsewhere in the non-breeding season (i.e. breeding endemic), such as Christmas Island frigatebird Fregata andrewsi (James and McAllan 2014; Tirtaningtyas and Hennicke 2015); (ii) one species that has been extirpated from all parts of its formerly extensive breeding range other than Christmas Island (i.e. neoendemic), being Abbott's booby Papasula abbotti (Morris-Pocock et al. 2012); and (iii) species originally occurring only on Christmas Island but from which populations have been translocated elsewhere (i.e. original endemic), for example, Christmas Island white-eye Zosterops natalis (Woinarski et al. 2014). With respect to this last category, family and business connections, resource needs and logistical tractability stimulated importation from Christmas Island to the Cocos (Keeling) islands of soil and timber, inadvertently with associated invertebrates in the late nineteenth and early twentieth centuries (Gibson-Hill 1950; Tweedie 1950), as well as some deliberate introductions of bird species (GibsonHill 1949a). Although we note some endemic subspecies in this account, our focus is on endemic species, largely because there is very uneven treatment of subspecies across taxonomic groups.

This study is of intrinsic interest for biodiversity conservation on one island. But it is likely that at least some of the findings, particularly in relation to biases in threatened species' listing, will have generalisations applicable to many other islands. Furthermore, the results from this study are likely to contribute to ongoing analyses of variation in the extent of endemism and its loss, and the factors associated with such variation, across sets of islands (Adler 1994), with such analyses currently constrained for some taxonomic groups by the relatively few islands with such information available.

\section{METHODS}

\section{STUDY AREA}

Christmas Island is a solitary sea-mount island, of volcanic origin (Hoernle et al. 2011), in the tropical eastern Indian Ocean (at 10² $25^{\prime} \mathrm{S}$ and $105^{\circ} 43^{\prime} \mathrm{E}$ ) (Figure 1). It is the sole emergent peak within a large chain of volcanoes that formed about 80 million years ago, with subsequent volcanic reactivation 40-35 million years ago (Trueman 1965), and possibly also between five and three million years ago (Borissova 1994). It has likely been continuously emergent for at least three million, and possibly up to ten million, years (Grimes 2001; Humphreys and Eberhard 2001; Namiotko et al. 2004) 2004), but with the most recent analysis indicating about 5.7-4.5 million years (Ali and Aitchison 2020). Its basaltic core is now mostly capped by a sequence of Tertiary limestones up to 250 metres thick. It is a rugged island, with a highest elevation of 361 metres. It has no outlying islets, and is distant in all directions from any other land mass. The main vegetation is tall rainforest. Freshwater environments are limited but diverse, and there is a complex mix of subterranean environments
(Grimes 2001; Humphreys 2014). About one-quarter of the island has now been cleared as part of a phosphate mining venture that has operated almost continuously since the island's settlement in 1887. A national park was established in 1980, and now encompasses $63 \%$ of the island (Director of National Parks 2014).

Biological inventory of the island has been episodic and incomplete. Following the initial spate of collections around the first decade of the island's settlement (see references in the Introduction), there was little sampling until some notable collecting in the 1930s (Chasen 1933a,b; Gibson-Hill 1947a,b,c,d,e,f,g), followed by another hiatus until more sampling for some taxonomic groups in the decades since the 1970s. The intermittent and variable nature of sampling for most taxonomic groups largely precludes the use of species' accumulation curves to assess the extent to which sampling is likely to have detected most or all species present.

\section{ASSESSING ENDEMICITY}

By definition, species (and other taxa) endemic to Christmas Island must occur there and nowhere else, other than the nuanced exceptions discussed above. Any species described from elsewhere (i.e. the type locality is not Christmas Island) is ineligible. Thus to compile a list of presumed or known endemic species, involves (mostly) the following steps: (1) documenting all species originally described from Christmas Island; (2a) determining if these species are valid (i.e. that they have not been lumped or dissolved into other species; and (2b) determining that they (and their synonyms) do not occur beyond Christmas Island. Of course, it is not necessarily so simple, because some species collected from Christmas Island may have been considered conspecific with species originally described from elsewhere, but subsequent taxonomic review has shown (or may in future show) that such assumed conspecificity is wrong. Furthermore, our process will detect only those species that have been collected on, and described from, Christmas Island. It is likely that there are many endemic species that have never been collected, and many that have been collected but not yet described.

Step 1: For several taxonomic groups, there have been recent comprehensive accounts of species recorded from Christmas Island with these accounts explicitly noting the number and identity of endemic species: these inventories include birds (James and McAllan, 2014), ants (Framenau and Thomas 2008), vascular plants (Claussen 2005), lichens (McCarthy 2018), molluscs (Tan and Low 2014), crabs (Orchard 2012), fish (Hobbs et al. 2014b), scale insects (Neumann et al. 2013, 2016), centipedes (Waldock and Lewis 2014) and subterranean fauna (Humphreys 2014). Unless we found compelling evidence to the contrary, or there have been subsequent taxonomic assessments, we used such recent reviews as the basis for recognising endemic species in these groups.

For other taxonomic groups, we used as the first step in the listing of endemic species a collation by James (2005) and James and Milly (2006) of species for which the type specimen was collected from Christmas Island and for which they found no subsequent records from 
A

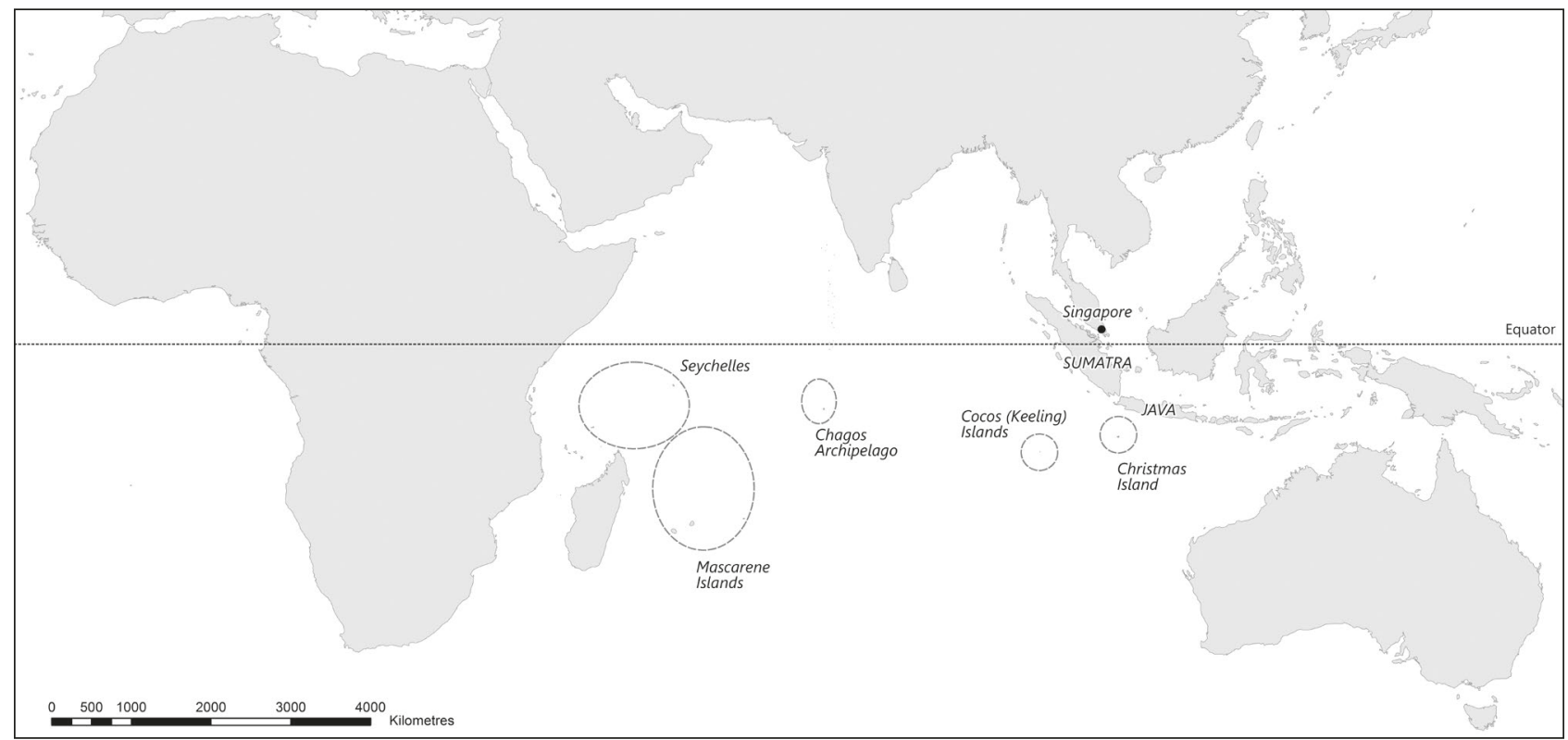

B

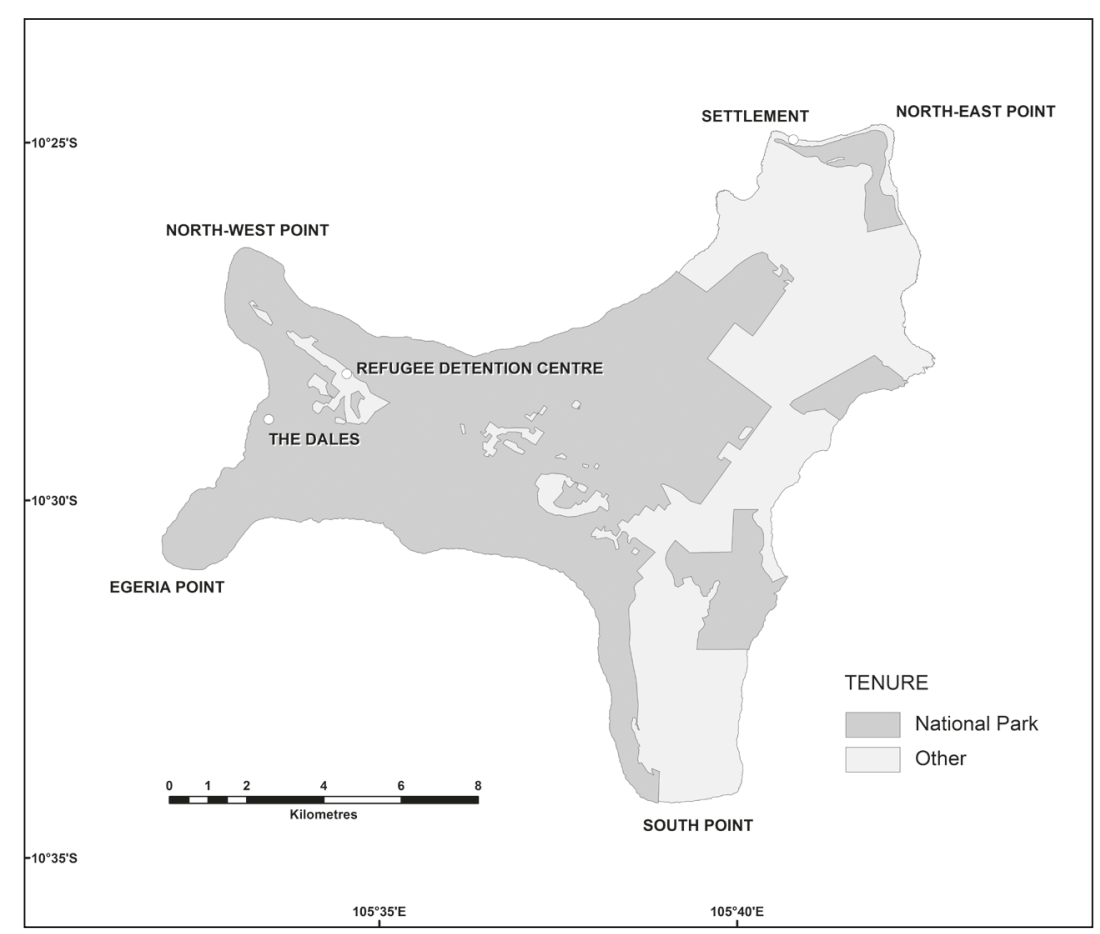

FIGURE 1 Location maps for Christmas Island. A) general location; B) map showing place names.

elsewhere, though we recognise that these compilations contained errors and omissions. The 2005-06 collations indicated that 225 species were nominally endemic to Christmas Island. We searched available taxonomic literature for new records of Christmas Island species published since these 2005-06 compilations as well as for additional species that may have been overlooked in 2005-06. We also extracted all records from the Atlas of Living Australia ('ALA') spatial database (see below), to cross-check for additional species that may be endemic to Christmas Island that were not included in the 2005-06 compilation.
Steps $2 \boldsymbol{a}$ and $2 \boldsymbol{b}$ : Making use of substantial recent increases in access to biodiversity information on-line, we searched three 'primary' databases for information on all of these nominally endemic species, to assess whether they are still recognised as valid species with spatially-explicit records only from Christmas Island: the Global Biodiversity Information Facility (https://www. gbif.org/ ; hereafter cited as 'GBIF'), the ALA (https:// www.ala.org.au/) and the Australian Fauna Directory (https://biodiversity.org.au/afd/home ; hereafter 'AFD'). As scholarly as these databases may be, they do contain omissions and errors, and sometimes contradict one 
another, so when they provided inadequate information we investigated as deeply as possible. We searched other relevant accessible taxonomic data bases (e.g. Mesibov 2010; Bieler et al. 2018; McCarthy 2018; Orthoptera Species File, 2018; Sierwald and Spelda 2018; Van Soest et al. 2018), used online search-engines and investigated the primary literature. We cross-checked all relevant animal taxa against the 31 published volumes of the 'Zoological Catalogue of Australia' (1983 to 2006: AGPS Canberra pre-1994, and ABRS and CSIRO Publishing Canberra from 1994), but they are cited specifically only when they provide additional information to their online successor, AFD. GIS-based assessments were impractical, as most of the records from early collections of Christmas Island biota (often the only records of these species) lacked precise locational information, so these records are typically not mapped in national or global databases.

As a further line of inquiry, we also searched through references in Google Scholar using combinations of 'Christmas Island' and family names.

Based on results from such searches, we allocated species to three categories: (i) confirmed endemic (Table 2), (ii) cited as endemic or probably so by collectors, but not yet described (Table 3), or (iii) previously claimed as endemic but now shown not to be (Table 4). Omission proved to be the most challenging issue. Under the taxonomic codes, newly described species are valid (if they meet naming rules) until a reviewer shows them to be the same as an earlier described species. Some species described from Christmas Island appear never to have been mentioned again, at least in the sources we found. Whilst such cases have never been invalidated by taxonomic revision, it is also difficult to state confidently that they are valid endemic species. Furthermore, taxonomy is appropriately not fixed, and future revisions will undoubtedly change taxonomic positions, as they have in the past.

\section{CONSERVATION STATUS OF ENDEMIC SPECIES}

We noted and tabulated the global (i.e. IUCN Red List) and Australian (i.e. under the Environment Protection and Biodiversity Conservation Act, 1999) conservation status for all endemic species, as at February 2019 (Table 1).

As a potential indicator of current conservation status, we also attempted to identify the most recent record for every endemic species, and we list that date when it was more than 50 years ago. For this we have drawn on the published literature, the online databases and several invertebrate surveys that are informally published (Campbell 1968; CSIRO Division of Entomology 1990; Surman 2004; James 2005, 2007; Framenau and Waldock 2006; James and Milly 2006; Kessner 2006; C. Pink, pers. comm.). This assessment also has some notable interpretational caveats, as the year of collection is often not given for records in the biodiversity databases we searched, and a lack of recent records for a taxon may simply be due to a lack of appropriate survey. Where possible, we also report on any other description of the abundance or distribution of endemic species on Christmas Island.

\section{RESULTS}

In the sections that follow, we document the inventory and taxonomic material relevant to endemic species, by major taxonomic groups. For some groups we could locate no relevant information.

\section{Kingdom EUBACTERIA Phylum FIRMICUTES}

\section{CLASS BACILLI}

A major disease threat emerged recently to the captive breeding program for two endemic Christmas Island reptile species. This invariably fatal disease was found to be due to infection with a previously unknown Enterococcus species, although the report documenting its occurrence did not formally describe it (Rose et al. 2017). This unusual bacterium was recorded not only from individuals in the captive breeding program for threatened endemic lizards, but also in individuals of Christmas Island populations of introduced lizards (Rose et al. 2017). Although the paper documenting its existence noted that there were no records of it from elsewhere, the current available information is insufficient to categorise it as native to Christmas Island, let alone endemic.

\section{Kingdom PROTISTA}

We acknowledge that the 'Kingdom Protista' is a diverse assemblage of eukaryotic organisms that are not plants, animals or fungi, but that are not all closely related (Keeling et al. 2009). However, it is beyond our scope to clarify such issues.

\section{Phylum APICOMPLEXA}

\section{CLASS ACONOIDASIDA}

A recent study has examined the blood parasites of some seabirds on Christmas Island and described a new species, Haemoproteus valkiunasi (Haemosporida: Haemoproteidae [although with family name given as Plasmodiidae in ALA]) from samples taken from Christmas Island frigatebirds Fregata andrewsi (Merino et al. 2012). All of the limited known records of this parasite species are from this endemic frigatebird species, so as currently known this parasite is also an endemic species.

\section{Kingdom PROTOZOA}

\section{Phylum MYCETOZOA}

\section{CLASS MYXOMYCETES}

These are fungus-like organisms known as plasmodial or acellular slime moulds. Ten species in four genera across four orders have been recorded from Christmas Island. According to GBIF all ten species have global distributions and so none are regarded as endemic. C.W. Andrews collected Arcyria obvelata (as A. flava), 
Lycogala epidendrum (as L. miniatum) and Stemonitis splendens in 1897-98, and H.D. Yorkston collected the other species in 1986-87.

\section{CLASS PROTOSTELIOMYCETES}

These are fungus-like organisms known as slime moulds, and regarded as primitive within that group. They occur mostly on bark and rotting wood. Two species have been recorded from Christmas Island, neither of which is regarded as endemic. Ceratiomyxa fruticulosa is globally distributed (GBIF), but C. sphaerosperma has a markedly disjunct distribution, with all known records from Africa and the Americas, except for a single Asian occurrence on Christmas Island. Both species were collected by H.D. Yorkston in 1986-87.

\section{Kingdom FUNGI}

The earliest collections of fungi on Christmas Island were made by J.J. Lister in 1887 (three species identified by M.C. Cooke in Hemsley 1890), followed by C.W. Andrews in 1897-98 (22 species identified by V. H. Blackman and A.L. Lister in Andrews 1900), and by H.N. Ridley in 1904 (50 species identified by M.G. Massee in Ridley 1906). The fate of these collections is largely unknown. Only five collections (three species) by Andrews and possibly one of Ridley's collections (one species) are discoverable through the Kew Fungarium online catalogue.

There followed a collecting hiatus until D.A. Powell, a naturalist working for the British Phosphate Commission, collected around a dozen species in 1968 (Reid 1969), and Powell and his assistant K.C. H'ng continued to make collections in the 1980s and early 1990s. Powell sent most of his material to Kew (K), but there are only 15 Powell/Powell and H'ng collections discoverable through the Kew Fungarium online catalogue, and several in Canberra (CANB) and Perth (PERTH).

Shivas and Hilton (1990) compiled a checklist of the fungi of Christmas Island, based on a 1-week survey in 1986, further collections by H.D. Yorkston in 1986-87, and collation of the limited previous collections. The compilation comprised c. 120 taxa, including 58 not previously recorded: 97 of the taxa were determined to species level (of which only three were described from Christmas Island), and 24 were determined only to genus level.

Following these collections, H. Lepp of the Australian National Herbarium made extensive collections in 2000 which were lodged mostly at CANB, followed by N.L. Bougher with the Western Australian Herbarium in 2016, who lodged most of his specimens at PERTH. The tally of non-lichenised fungi known from the island now stands at 132 species.

Three species from the early collecting period 1888-1904 were described as new at the time. The first was the earthstar Geastrum andrewsii (Blackman
1900). The only collection of this species was by Andrews in 1897-98, from which the holotype was designated. It has not been collected since, although a photograph by Peter Goh for the month of March in the 1991 Christmas Island Natural History Association calendar may be this species. It is still regarded as endemic to the island (Shivas and Hilton 1990), but is not listed in ALA and is listed as 'doubtful' in GBIF. Massee described two new species from Ridley's 1904 collections (Ridley 1906a). The type of Poria chlorina is lodged at the New York Botanical Garden Herbarium, but this taxon has since been synonymised with the much more widespread Ceriporia mellea (Berk. and Broome) Ryvarden 1978. Ridley (1906a) also listed 'a small white agaric' Favolus albidus Massee as a new species, but Shivas and Hilton (1990) noted that this species was actually described in 1902 by Massee from specimens collected in Thailand, and the placement of an agaric in the genus Favolus is problematic anyway.

Two species in the earthstar genus Radiigera were described by Reid (1986) from material collected on Christmas Island in 1983 and 1984, and thought then to be known only from there. However, Domínguez de Toledo and Castellano (1996) examined the holotype of Radiigera asperata D.A. Reid and determined it to be an immature, unopened Geastrum species. Given the only Geastrum species known from the island is the endemic $G$. andrewsii, in all likelihood it was that species in which case it has been collected several decades after Andrews' original 1897-98 collection. Radiigera asperata was never recorded as occurring elsewhere, and so the name can no longer be applied. Domínguez de Toledo and Castellano (1996) also regarded Radiigera termitariicola D.A. Reid as synonymous with Phialastrum barbatum (Dissing and Lange) Sunhede 1989, itself originally described as Geastrum barbatum Dissing and Lange (1962) from the Congo. Based on this synonymy, $R$. termitariicola can no longer be regarded as endemic to Christmas Island.

In addition to Geastrum andrewsii, there appears to be only one other non-lichen fungus endemic to Christmas Island. Aecidium alchorneae-rugosae Gjaerum and D.A. Reid 1983 (Pucciniaceae) is common all over the island on its host Alchornea rugosa (Euphorbicaeae), especially in drier areas (PG pers. obs.). Neither of the two described endemic fungi species is listed as threatened nationally or globally.

\section{LICHENS}

McCarthy (2018) collated checklists of lichens for all of Australia's main oceanic islands. He listed 101 taxa (100 species) for Christmas Island, and stated that four of these species are endemic: Lithothelium quiescens, Strigula elixii, Strigula natalis and Trichothelium oceanicum. These names are recognised in GBIF and all (of the few) locational records in that database for these four species are from Christmas Island. Lithothelium quiescens is corticolous and Trichothelium oceanicum 
is follicolous, and both are widespread and common (McCarthy 2001a,c). Strigula elixii and S. natalis are saxicolous and scarce, with the latter known from one site only. None of the four described endemic species is listed as threatened nationally or globally.

The list of species from Christmas Island (McCarthy 2018) is mostly based on results from a recent (2000) survey (McCarthy, 2001a,b,c; McCarthy and Elix, 2002). There are few historical records and hence no indication of changes in status. Although the 2000 sampling study was extensive, McCarthy and Elix (2002) considered that the known inventory of 100 species was a major under-estimate of the actual number of species present: the tally 'does not include least 10 unidentified species each of Graphidaceae, Thelotremataceae, Pyrenulaceae and other saxicolous and corticolous pyrenolichens, as well as numerous sterile and apothecial crusts on limestone, bark, soil and leaves. The addition of 50 or more taxa that were not collected during our visit (a conservative estimate considering the forest canopy flora and much of the southern half of the island remain largely unexplored) would bring the total close to 250' (McCarthy and Elix 2002).

\section{ALGAE}

Gepp and Gepp (1905) listed 21 species and one indeterminate species of marine algae from a collection made by H.N. Ridley in October 1904 from flying Fish Cove and Waterfall Cove. This included one new species of red algae, Halymenia polyclada, which remains a valid species, but has since been recorded from the Seychelles (GBIF; Table 4). Other than being mentioned again in Ridley (1906a), we have found no further records of this species from Christmas Island, but it is not listed as threatened nationally or globally.

\section{Kingdom PLANTAE}

\section{Phylum BRYOPHYTA}

Gepp and Gepp (1905) listed 15 species of mosses (Class Bryopsida) from collections made by C.W. Andrews in 1897-98 and H.N. Ridley in October 1904. These are mostly widespread species in Southeast Asia. However, their account contained two new species described by Fleischer as Ectropothecium micronesiense and Isopterygium jelink. Both are recognised as valid species by ALA and GBIF, and neither database list records from elsewhere. Streimann and Curnow (1989) also treated both species as valid and endemic to Christmas Island (Table 2), even though Gepp and Gepp (1905) stated that Isopterygium jelinki occurs on Sumatra. Neither endemic species of moss has been reported since 1904, but neither is listed as threatened, nationally or globally.

Gepp and Gepp (1905) also reported one widespread species of liverwort (Class Hepaticopsida) but we are not aware of any reports of hornworts (Class Anthocerotopsida) from Christmas Island, or of any collections since 1904.

\section{Vascular Plants}

The vascular flora of Christmas Island is well inventoried, with extensive early collections at about the time of the island's settlement (Hemsley 1890; Ridley, 1891, 1906a,b), and some notable more recent surveys and inventories, including studies to assess the conservation status of some species (Du Puy 1988, 1993; Holmes and Holmes 2002; Claussen 2005; Green et al. 2010). Claussen (2005) reported that there are 213 species of native plant on the island.

Although the early collections led Ridley (1906a) to list 34 species of vascular plants as endemic to the island, about half are no longer considered so (Table 4). The 17 species still recognised as endemic are: Abutilon listeri, Arenga listeri, Asystasia alba, Brachypeza archytas, Colubrina pedunculata, Dicliptera maclearii, Flickingeria nativitatis, Grewia insularis, Hoya aldrichii, Illigera elegans, Ischaemum nativitatis, Pandanus christmatensis, Pandanus elatus, Peperomia rossii, Phreatia listeri, Pittosporum nativitatis and Zeuxine exilis. With a few exceptions, all are species recognised by GBIF, and for most species all locational data in GBIF are from Christmas Island. The exceptions are that GBIF includes no locational data for Pandanus elatus; it includes a record from Kiribati (Pacific Ocean) for Flickingeria nativitatis, which we discount as a case of mistaken island name; and there are early records for 'Indonesia' (without explicit locational information) for Dicliptera maclearii, Arenga listeri and Hoya aldrichii, which we assume simply represent historically imprecise geographical descriptors. Pittosporum nativitatis is treated in GBIF as a synonym of $P$. ferrugineum subsp. ferrugineum, but is maintained as a valid species endemic to Christmas Island in ALA and CHAH Australian Plant Census, consistent with its reinstatement as a species in a recent review of the genus (Cayzer et al. 2000).

Two species for which Christmas Island is the type locality and which have long been considered endemic (Claussen 2005) are no longer recognised as such. Asplenium listeri is now recognised to be much more widely distributed (Ohlsen et al. 2015) and Zehneria alba has been subsumed in the more widespread Z. mucronata (CHAH Australian Plant Census: http://www.chah.gov.au/ apc/about-APC.html, but is still recognised as specifically distinct in GBIF). Ardisia pulchra is recognised by GBIF as a valid species endemic to Christmas Island, but is subsumed within the more wide-ranging $A$. sanguinolenta in CHAH's Australian Plant Census and ALA. Likewise, Saprosma nativitatis is recognised by GBIF as a valid species endemic to Christmas Island, but is subsumed within the more wide-ranging Amaracarpus pubescens in CHAH's Australian Plant Census and ALA.

There are records for all but two endemic plant species within the last 50 years, notably including the re-discovery of Zeuxine exilis in 2009 more than 100 years after its only previous collection in 1904 (Green et al. 2010). However, Peperomia rossii is known only from the 1898 type collection. Only one endemic plant species is listed as threatened: Arenga listeri is listed globally as 
Endangered. Three native plants occurring on Christmas Island (Asplenium listeri, Pneumatopteris truncata and Tectaria devexa var. minor) are listed as threatened nationally, but all also occur elsewhere (Table 3).

\section{Kingdom ANIMALIA}

Eleven animal phyla reported from Christmas Island are considered below. Phylum Chaetognatha has been reported in the plankton by Davies and Beckley (2010), but no species have been identified. Nineteen more phyla have not been reported at all. The nomenclature and taxonomic sequence of animals follows AFD unless stated otherwise.

\section{Phylum PORIFERA}

The Porifera of Christmas Island is poorly studied and has not been reviewed for over 100 years. Dendy (1887) described one species (Table 4). Kirkpatrick (1900) listed 32 species from Andrews' collection and described seven of them as new. He later described one more species, Murrayona phanolepis (Kirkpatrick 1910), which is now recognised as the sole representative of a monotypic genus and family (Murrayonidae), but it is not endemic to Christmas Island. Sponges collected by the Western Australian Museum in 1987 have not been identified (Marsh and Fromont 2000), and the Raffles Museum of Biodiversity Research expedition in 2010-12 did not report on Porifera (Tan et al. 2014a). Hooper and Wiedenmayer (1994) updated the taxonomy and nomenclature, but provided no new records. Although sponges do not form a prominent feature of the island's coral reefs (Marsh and Fromont 2000), it is probable that the species complement is more diverse than currently known, particularly considering that all of the reported collections come from a single locality, Flying Fish Cove. Of the nine species whose type locality is Christmas Island, Tethya affinis has been synonymised with Tethya deformis (Hooper and Wiedenmayer 1994) and six have been recorded beyond Christmas Island (ALA, AFD, GBIF: see Table 4). Haliclona irregularis (Kirkpatrick 1900), described from Christmas Island, has three homonyms described from elsewhere, H. irregularis (Kieschnick 1896), H. irregularis (Czerniavsky 1880) and H. irregularis (Brøndsted 1924) (Van Soest et al. 2018).

Following Burton (1959), we recognise two endemic species of Porifera from Christmas Island, Oceanapia sessilis and Haliclona innominata, both of which are in the Class Demospongiae (Table 2). Although we are aware of no records for these endemic species since 189798 , neither is listed as threatened, nationally or globally.

\section{Phylum CNIDARIA}

The surface of Christmas Island is dominated by limestone karst that was built in part by coral growth over millions of years, and living corals are obviously essential elements of existing coral reefs, but ironically, the Cnidaria of Christmas Island are largely neglected (Beeton et al. 2010). Hard corals have received some little attention recently (Done and Marsh 2000; Richards and Hobbs 2014) but other Cnidarians are barely documented. Richards and Hobbs (2014) listed 169 known species of Scleractinia coral and five species of non-scleractinian coral (three Hydrozoa and two Octocoralia). Their species accumulation curves were close to asymptotic, although the southern coast was not surveyed. Meanwhile, soft corals, which dominate the southern coast, have received no study. Hobbs et al. (2013) listed three widespread Actinaria anemone species, but they did not attempt to be comprehensive. Tan et al. (2014b) recorded an additional Actinaria from submarine caves that was identified to the genus Edwardsiella, for which no species are known in the tropics (GBIF). Nektonic forms have not been reported. Planktonic forms were reported by Davies and Beckley (2010) only as 'Cnidaria'. There is no evidence that Christmas Island has any endemic species of Cnidaria (Richards and Hobbs 2014), with the possible exception of the Edwardsiella sp. Nevertheless, the composition of the coral community is biogeographically unique, but it is threatened by local pollution and invasive species (Richards and Hobbs 2014).

\section{Phylum PLATYHELMINTHES}

Platyhelminthes have been found on Christmas Island only recently, and little has been published on them. Humphreys and Eberhard (2001) recorded a single unidentified species of 'free-living' flatworm (Turbellaria) from Jane-up Well, which was thought to be styogobitic. James (2007) recorded two morphospecies of terrestrial 'turbillarians'. One of these might be the widespread Caenoplana coerulea Moseley 1877 (Tricladida, Geoplanidae), whilst the other might be a turbillarian or a misidentified nemertean (DJ pers. obs.). No parasitic Platyhelminthes have been recorded.

\section{Phylum NEMERTEA}

Nemerteans have not been described from Christmas Island, but specimens of at least one terrestrial species (Monostilifera) have been collected and await determination (PG pers. obs.). It may be close to Geonemertes pelaensis Semper 1863, which has a distribution encompassing islands in the western Indian Ocean, to the south-east of India and South-East Asia (Moore et al. 2001). It is also possible that the Christmas Island taxon is a new and endemic species. No marine nemerteans have been reported.

\section{Phylum BRACHIOPODA}

A single species of Brachiopod has been recorded from Christmas Island, and it was described as a new species, Thecidellina blochmanni by Dall (1920). Marsh and Fromont (2000) stated that it had not been recorded elsewhere, but GBIF lists a specimen from Guam and AFD includes Madagascar in the distribution. Therefore, it is not considered endemic to Christmas Island. It was collected at least as recently as 1987 (Marsh and Fromont 2000). 


\section{Phylum MOLLUSCA}

The molluscs of Christmas Island are diverse and have been well-studied compared to most invertebrate groups. There have been two significant modern studies, the first by the Western Australian Museum (Wells and SlackSmith 2000) and the second by the Raffles Museum of Biodiversity Research (Tan and Low, 2014). There is also a popular book depicting a good selection of marine mollusc species (Wells et al. 1990), though it is now dated.

A remarkable collection was made incidentally by $\mathrm{Mr}$ R. Kirkpatrick of the British Museum while dredging for the Pharetronid sponge Murrayona phanolepis, off North East Point, probably in January 1916. A sample of dredged sand rich in 'small' (length $<5 \mathrm{~mm}$ ) snails passed to the Australian Museum from which Iredale (1917) described five new species in four new genera, and about 40 years later Laseron described 34 new species and eight new genera (Laseron 1956a,b, 1958). Most of these remain valid taxa, and while many of the species are now known to have wider distributions, some seem to be endemic. However, few of the species and none of the endemic ones have been recorded from Christmas Island again.

Tan and Low (2014) reviewed all previous studies except for an unpublished report of a survey of terrestrial mollusc species (Kessner 2006). They listed the known Christmas Island fauna as 760 species from 130 families and four classes (four species in three families of Polyplacophora; 104 species in 20 families of Bivalvia; 640 species in 101 families of Gastropoda, and 12 species in six families of Cephalapoda). Still, their species accumulation curve suggests that the total fauna is considerably larger. They listed the species they considered to be endemic to Christmas Island: one Bivalvia, 38 Gastropoda, no Polyplacophora and no Cephalapoda. However, there is low agreement on taxonomy and distribution among authorities (Tan and Low 2014; Bieler et al. 2018) and taxonomic databases (ALA; AFD; GBIF). Schwartziella lata is synonymised with Zebina triticea and Schwartziella oceanica is synonymised with Zebina ephamilla by AFD and ALA. Eleven Gastropoda species from Tan and Low's list of endemics have locational records beyond Christmas Island in either ALA, AFD or GBIF and therefore are not considered endemic here (Table 4). The remaining one Bivalvia and 26 Gatropoda species (seven terrestrial and 19 marine) have type localities at Christmas Island and are not recorded from elsewhere, so are taken here to be endemic (Table 2), with the following considerations. Five species (Semperula insularis, Succinea solitaria, Lamprocystis mabelae, Lamprocystis mildredae and Lamprocystis normani) are not recognised in any of ALA, AFD or GBIF, but we surmise that they have been overlooked rather than synonymised and follow Gomes and Thomé (2004) and Tan and Low (2014) in recognising them as valid. Tomlin (in Laidlaw 1935) considered there was no difference between L. mildredae and L. normani, but
Kessner (2006) recently collected and distinguished both. In addition, we note an additional apparently endemic species described by Laseron (1956b) that was not included in Tan and Low (2014): Cyclonidea carina is recognised as a valid species in ALA and GBIF, although with no locational records. Also, four undescribed putative species have been reported that might be endemic Gastropoda species (Table 3).

Eighteen of the 27 known endemic Mollusca species have not been certainly recorded for over 50 years (Table 2). This is concerning given that the group has been surveyed comparatively well. Nevertheless, none of the endemic Mollusca species are listed as threatened, nationally or globally.

\section{Phylum ANNELIDA}

There has been very little reporting of annelids from Christmas Island. Gates (1935) provided the only available list of Oligochaeta, which was 13 species. One of these, Polypheretima brevis (Rosa 1898) was originally described from the Island (Andrew's collection) as Pheretima brevis, but it has since been recorded from Tonga (Easton 1984) (Table 4).

Humphreys (2014) reported three species of Polychaeta from anchialine environments, a Syllidae sp. a Nerilla sp. (Nerillidae) and a Prionospio sp. The last is considered to be a new species, based on an unpublished molecular phylogeny by $\mathrm{K}$. Worsaae (pers. comm.) at the University of Copenhagen (Table 3). No members of the Class Hirudinida (leeches) have been recorded. No annelid species from the Island are listed as threatened, nationally or globally.

\section{Phylum ARTHROPODA}

The arthropods are the largest and most diverse phylum of the animal Kingdom. Representatives of all four subphyla have been recorded on Christmas Island.

\section{Phylum ARTHROPODA}

\section{Subphylum Crustacea}

Two of the five crustacean classes (Branchiopoda and Remipia) have not been recorded at Christmas Island. The remaining three classes are treated below.

\section{CLASS OSTRACODA}

Ostracoda have recently been discovered on Christmas Island in anchialine systems and various freshwater environments including subterranean streams, springs and tufa flows, but not in the marine environment (Humphreys and Eberhard 2001; Humphreys 2014). Their diversity is surprising, their endemism extraordinary and their biogeography astounding (Humphreys 2014). About six species in four families have been discerned, but while the exact number is clouded by taxonomic uncertainty, it is evident that greater diversity will emerge with further sampling and sorting. In just two decades three new species and two 
new genera have been discovered and described (Table 2), namely: Humphreysella baltanasi, Microceratina martensi and Isabenula humphreysi (Namiotko et al. 2004; Kornicker et al. 2006; Humphreys et al. 2009; Rossetti et al. 2011). In addition Vestalenula sp. E was recognised as new by Rossetti et al. (2011), but left in open nomenclature because only one individual was known, and Humphreys (2014) recognised a new species of Penthesilenula (Table 3). No ostracod species from the Island are listed as threatened, nationally or globally.

\section{CLASS MAXILLOPODA}

Murray and Andrews made a small collection of marine plankton in 1908 that was rich in Copepoda, from which 12 new species and a new genus were described (Farran 1911, 1913). Not surprisingly, none are endemic (Table 4). Three of these have been synonymised into wider ranging species and nine are accepted species but have wider distributions (Table 4).

A subterranean copepod considered to be a new species and genus in the family Arietellidae is very likely endemic (Bruce and Davie 2006; Humphreys 2014).

\section{CLASS MALACOSTRACA}

Five orders of the large and diverse crustacean Class Malacostraca recorded at Christmas Island are treated below. Davies and Beckley (2010) collected planktonic forms of three other orders (Cumacea, Mysidacea, and Euphausiacea), but these were identified only to Order level. These and seven more orders never reported from Christmas Island are not considered further here.

\section{Order Stomatopoda}

Ahyong (2014) listed eight species of mantis shrimps known from Christmas Island. One of these, Chorisquilla quinquelobata, was described from Christmas Island as Gonodactylus quinquelobatus from specimens collected by Harms in 1933. Ahyong (2014) considered it to be endemic to Christmas Island, and this treatment is supported by AFD, ALA and GBIF. A single female Chorisquilla quinquelobata was collected by hand from Thundercliff Cave in 2008, which was the first record since 1933 (Ahyong 2014). However, it is not listed as threatened, nationally or globally.

\section{Order Amphipoda}

No endemic species are known, although the fauna is not thoroughly documented. Specimens of the genus Leucothoe (Leucothoidae) have been recorded in anchialine systems, and of the genus Floresorchestia (Talitridae) in damp caves and adjacent to anchialine pools (Humphreys 2014)

\section{Order Isopoda}

There is very little literature on isopods from Christmas Island. One species, Tylos nudulus, was described by Budde-Lund (1906) from Andrews' 1897-98 collections, although Andrews (1900c) made no reference to terrestrial (littoral) isopods. This species is still considered to be valid and endemic to Christmas Island (GBIF, AFD, Hurtado et al. 2014). We have found no records subsequent to the type series. However, James (2007) reported three morpho-species of isopods, one littoral and two terrestrial species. Humphreys (2014) listed 16 terrestrial oniscidean isopod species from six families that have been recorded in subterranean environments on the island, including seven putative undescribed species (four Myrmecodillo, two Papuaphiloscia and one Elumoides) (Table 3). No endemic isopod species is listed as threatened.

\section{Order Thermosbaenacea}

The Thermosbaenacea is a small order restricted to subterranean waters. It was previously known in Australia from a single species (AFD), Halosbaena tulki, which is from a cave in tropical Western Australia (Poore and Humphreys 1992). Specimens of a Halosbaena have recently been discovered in caves on Christmas Island that represent an undescribed species (Humphreys 2014) (Table 3).

\section{Order Decapoda}

The crab fauna of Christmas Island is widely and justifiably celebrated for its diversity, abundance and ecological importance. There have been notable recent reviews and popular accounts (Hicks et al. 1990; Orchard, 2012). Many species are considered endemic, with this number increasing because of surveys in specialised subterranean habitats (Naruse and Ng 2014; Tan et al. 2014b) and because recent taxonomic scrutiny has raised to specific status some Christmas Island populations formerly considered to be part of more wide-ranging species (Ng and Davie 2012).

Pocock (1889) described the first crab species from Christmas Island, the red crab, as Hylaeocarcinus natalis (now Gecarcoidea natalis), which has subsequently been shown to be a pivot of the island's ecology (Green et al. 1996). Andrews (1900a) reported on five species from his 1897-98 collection, all of which he attributed to species already described from elsewhere. However, the blue crab he recognised as Cardisoma carnifex has subsequently been recognised as specifically distinct (Discoplax celeste) and endemic to the island ( $\mathrm{Ng}$ and Davie 2012), with subsequent taxonomic change to Tuerkayana celeste (Guinot et al. 2018). Andrews' subsequent collection in 1908, mostly of intertidal species, was reported on by Calman (1909). This comprised about 67 species, of which four species were described as new: Lioxanthodes alcocki, Sesarma murrayi, Hyastenus andrewsi and H. uncifer, with Lioxanthodes described as a new genus. Two of these species have since been synonymised with species earlier described from elsewhere, and the other two subsequently also recorded from elsewhere (Table 4).

Collections in $1932-33$ by J.W. Harms, in 1932 by M. Tweedie and in 1938-40 by Carl Gibson-Hill resulted in further substantial advances in the inventory of 
the Christmas Island crab fauna, with 13 new species described by Ward (1934), including the new genera Tweedieia and Proechinoecus, two new species described by Balss (1934), one by Gordon (1935), and one by Shen (1936). Of these newly-described species, only two, Karstarma jacksoni and Echinoecus sculptus, are still considered endemic to Christmas Island (Tables 2 and 4). Oddly, both GBIF and ALA list a 1932 record of Echinoecus sculptus from Kiribati, Pacific Ocean, but this is likely to be a geographic error, as the collection date coincides with the time at which Tweedie collected the type material on Christmas Island. Tweedie (1947) provided a then-comprehensive inventory of the c. 50 species of Brachyura recorded from Christmas Island, including some substantial taxonomic re-assessments of species previously named from there.

Morgan (2000) listed a total of 204 species of decapods, many of which were not determined to species level. However, he did not attempt to identify endemic species. Since then there has been a series of surveys, particularly of the island's subterranean environments, and further taxonomic reviews, that have added many more species, including the discovery or taxonomic recognition of five species of crabs (Davie and $\mathrm{Ng}$ 2012, 2013; Ng and Davie 2012; Naruse and Ng 2014), a stygobitic prawn, Macrobrachium xmas (Fujita et al. 2015), and an anchialine cave shrimp, Procaris noelensis (Bruce and Davie 2006), all considered endemic to Christmas Island (Table 2). One of the newly discovered crabs, Christmaplax mirabilis, also represents an endemic genus (Naruse and $\mathrm{Ng} 2014$ ).

In addition, since the inventory published by Morgan (2000), there have been several recent reviews of components of the Christmas Island decapod fauna. Mendoza et al. (2014) compiled records of 83 species of Xanthidae from Christmas Island, of which 30 were additions to the known local fauna, but none were considered endemic. $\mathrm{Ng}$ and Naruse (2014) compiled records of seven species of reef lobster (Palinuridae, Scyllaridae and Enoplometopidae), of which one was locally new but none were endemic. Osawa (2014) listed nine species of Porcelanidae, including five (or four) new records but no endemics. Tan et al. (2014b) reported on the Decapod (and other) fauna of submarine and associated anchialine caves of Christmas Island, noting particularly that there were at least three undescribed and presumed endemic species, including a new genus of Paguridae (Table 3). This brings the total species list of decapods to c. 249.

We conclude that ten described Decapod species are endemic to Christmas Island (Table 2). Most of these represent recent discoveries or the consequences of recent taxonomic revision. Echinoecus sculptus (Pilumnidae) is recognised as valid and known only from the type locality by Davie (2002); it is symbiotic with the intertidal echinoid Colobocentrotus atratus. All of the endemic species have been recorded recently, but some are known from very few specimens and a small number of locations on the island: for example, Procaris noelensis is known from only a single specimen.
The endemicity of Christmas Island's iconic red crab Gecarcoidea natalis is not clearly resolved: we treat it as endemic species, consistent with most recent assessments (e.g. Orchard 2012; Morris et al. 2018). However, it also occurs on the Cocos (Keeling) islands (Tweedie 1950), where it is patchily abundant on Pulu Keeling (North Keeling Island) (JW pers. obs.) and scarce in the northern parts of the southern atoll (DJ pers. obs.; IAW McAllan pers. comm.). It has been known from the Cocos (Keeling) islands group for more than a century (Wood Jones 1909). This occurrence beyond Christmas Island may be a result of deliberate or accidental introduction, or sporadic colonisation. Tweedie (1950) asserted that 'there is no doubt that they have been introduced (to Cocos (Keeling) islands) with soil imported from there (Christmas Island)'. Alternatively, Orchard (2012) noted that 'low numbers ... occur on North Keeling Island' and considered that they derived from 'larvae that drifted from Christmas Island. North Keeling red crabs have never been observed to breed'. GBIF also includes two 1970s records of this species from islands off western Thailand, but these records are unlikely to represent a breeding population. Populations of Gecarcoidea natalis on Christmas Island have been conspicuously and severely depleted by supercolonies of yellow crazy ants since the first supercolony was reported in 1989 (Green and O'Dowd 2009).

The Christmas Island crab fauna is unusually famous, charismatic and ecologically significant, and has attracted international scientific interest. Other decapods are significant examples of ancient lineages that, along with other crustaceans, are shedding new light on evolution and biogeography in the marine environments of the early Mesozoic. However, no species is listed as threatened, globally or nationally.

\section{Phylum ARTHROPODA}

\section{Subphylum Chelicerata}

The chelicerate Class Arachnida is treated below; the Class Picnogonida has not been recorded.

\section{CLASS ARACHNIDA}

The arachnid fauna is poorly known, despite collections in 1887, 1897-98, 1939, 1964, 1989 and 2005 (Pocock 1889, 1900; Savory 1943, 1947; Campbell 1968; CSIRO Division of Entomology 1990; Framenau and Waldock 2006). Seven subterranean fauna collections were made between 1987 and 2013, but the fauna is still considered poorly known (Humphreys 2014). A recent review of spiders is unfortunately incomplete and not formally published (Framenau and Waldock 2006), and the taxonomy of the Araneae is poorly resolved in the wider region. Framenau and Waldock (2006) listed 37 Araneae species, but also 40-50 additional taxa not identified beyond genus. Humphreys (2014) listed eight troglomorpic spiders, of which three species are additional to the above. Also recorded are two species of 
Scorpiones, at least eight species of Pseudoscorpiones, one species of Amblypygida and one species of Schizomida (Savory 1943, 1947; CSIRO Division of Entomology 1990; Humphreys 2014). The Acari have been little studied and never reviewed. Neumann (1904) described a single species of tick, Ixodes nitens, from a specimen of the endemic Rattus macleari. Campbell (1968) noted the presence of dog ticks Rhipicephalus sanguineus on domestic dogs and/or cats. More recently, Humphreys and Eberhard (2001) reported two indeterminate Acarina from subterranean environments. An arthropod voucher collection made from 2004-06 contained 11 morpho-species of mites and two of ticks (James 2007). Thus there are 54 identified species of Arachnida from the island and possibly 50-60 further species that have been collected but not identified fully.

Nine arachnid species have been described from Christmas Island: one Amblypygida, one Acari, one Scorpiones, two Pseudoscorpiones and four Araneae (Tables 2 and 4). Of these, one species is not endemic. Metawithius murrayi, described by Pocock (1900), has subsequently been recorded widely in Indonesia and the Andaman and Nicobar Islands (Harvey 2015). In their original description of the whip scorpion Charon gervais, Harvey and West (1998) speculated that it may have been introduced to Christmas Island from Java, but we found no records beyond Christmas Island. GBIF lists a record of Ariadna natalis from Natal, South Africa, but this is almost certainly an error resulting from the specific epithet. ALA and GBIF list records of Idioctis xmas from Queensland, Australia, but this is also almost certainly an error resulting from the location where the specimens are housed. Accordingly, we recognise Charon gervaisi and these last two Areneae species, along with Filistata gibsonhilli and Heteropoda listeri, the tick Ixodes nitens (recognised also as a valid endemic species in a recent global review: Guglielmone et al. (2010)), the scorpion Hormurus polisorum, and the pseudoscorpion Paratemnoides pococki as endemic species, being valid species never recorded beyond Christmas Island (Table 2). In addition, three undescribed taxa have been reported that might be endemic Arachnida species (Table 3). Given the poor taxonomic resolution of the group, there might be more undiscovered endemic species. For example, an eyeless troglomorphic spider, tentatively identified as Olin platnicki Deeleman-Reinhold 2001, differs from the type population (in Sulawesi) that has 'reduced eyes' (Humphreys 2014). An Acarina parasitic on O. platnicki might also be endemic (Humphreys 2014).

Ixodes nitens is known only from a few individuals collected from the last specimens of Rattus macleari, before it became extinct between 1901 and 1904 (Durham 1908; Green, 2014), so the tick presumably became extinct at the same time (Mihalca et al. 2011; Colwell et al. 2012). Ariadna natalis has not been recorded since the type collection in 1897-98. Filistata gibsonhilli has not been recorded since the type collection in 1939, but a filistatid spider (not determined to species level) reported by (CSIRO Division of Entomology 1990) may represent this species. Heteropoda listeri was collected in 1897-98 and 1939 but not since. Idioctis xmas is rarely encountered and might be known only from the type collection taken in 1983. Hormurus polisorum is rare but was collected as recently as 2006 (ALA). No species of Arachnida from Christmas Island is listed as threatened, nationally or globally.

\section{Subphylum Myriapoda}

Two classes of myriapods (Chilopoda and Diplopoda) have been recorded from Christmas Island and two have not (Pauropoda and Symphyla).

\section{CLASS CHILOPODA}

The centipede fauna of Christmas Island was reviewed by Waldock and Lewis (2014). The collections have been limited, and several key specimens are incomplete and hence difficult to determine. Waldock and Lewis (2014) listed ten species from historical sources and recent records, but four of these were identified only to genus. Cryptops inermipes, described from Christmas Island by Pocock (1889), is still recognised as a valid species (Lewis 2011). It is known definitively only from the type specimen, but two other incomplete specimens from Christmas Island, one collected in 1887 and identified as C. hortensis (Pocock 1889) and the other in 2006, may be referrable to it (Waldock and Lewis 2014).

\section{CLASS DIPLOPODA}

The Christmas Island millipede fauna was reviewed by Jeekel (2006) and Mesibov (2010). From specimens collected by Lister in 1887, Pocock (1889) described two species, Cylindrodesmus hirsutus and Spirostreptus exocoeti, the former constituting a new genus, albeit with other congeneric species subsequently reported from elsewhere (Pocock 1900). Both of these species, and another (the non-endemic Orthomorpha coarctata), were also reported by Pocock (1900) from Andrews' 1897-98 collections. Cylindrodesmus hirsutus has since been found to have a wide distribution beyond Christmas Island (Jeekel 2006).

A collection in 1933 by J.W. Harms was documented by Jeekel (2006), who noted the previously reported three species and added a further five species (Leptogoniulus sorornus, Solaenaulus butteli, Prosopodesmus jacobsoni, Monographis sp. and an undetermined Siphonotidae species). Of these, at least the first three are widely distributed beyond Christmas Island and may have been introduced there. Another wide-ranging species, Trigoniulus corallianus, was earlier recorded from the island by Jeekel (2001). Jeekel (2006) also transferred S. exocoeti to Hypocambala, a treatment followed by AFD.

There has been little subsequent collection. For example CSIRO Division of Entomology (1990) did not document any diplopod records in their invertebrate 
survey of the island, but that survey resulted in the lodgement of four specimens of Asiomorpha coarctata (=Orthomorpha coarctata) in the ANIC. However, collections in 1998 resulted in the description of two additional cave-dwelling species: Lophoturus speophilus and L. humphreysi (Nguyen Duy-Jacquemin 2014).

The online database Millibase (Sierwald and Spelda 2018) recognises $S$. exocoeti (as Iulomorpha exocoeti, with synonym Hypocambala exocoeti), Lophoturus speophilus and L. humphreysi as valid species endemic to Christmas Island. Mesibov (2010) characterised Hypocambala exocoeti as a 'tramp' species, and Mesibov (2018) noted it as introduced to Australia; likewise, the AFD includes the enigmatic comment 'introduced from ?'. Given that it was collected on Christmas Island prior to the island's human colonisation, and that it has not been found elsewhere, we consider instead that it is native and endemic to Christmas Island.

Whereas Lophoturus speophilus and L. humphreysi were collected in 1998 (from < 10 specimens and the holotype only, respectively), we are aware of no records of Hypocambala exocoeti since Harms' collections of 1933 (Jeekel 2006). Notwithstanding the lack of documented records for Hypocambala exocoeti for more than 80 years, and the few specimens and highly localised distribution of the two endemic Lophoturus species, none of the three endemic species is listed as threatened, nationally or globally.

\section{Subphylum Hexapoda}

All three classes of hexapods (Collembola, Entognatha and Insecta) are recorded from Christmas Island.

\section{CLASS COLLEMBOLA}

There are no endemic species known. About 850 specimens belonging to 15 morpho-species of springtails were identified from the CSIRO collection in 1989 (CSIRO Division of Entomology, 1990). Although only one was determined to species level, it was considered that no genera and probably no species are endemic to Christmas Island.

\section{CLASS ENTOGNATHA}

Of the two orders within Entognatha (Diplura and the Protura), only the former has been recorded from Christmas Island, with a single species collected from subterranean habitats in 1989 (Humphreys and Eberhard 2001). It was considered to be a new species of Cocytocampa (Family Campodeidae) and likely to be endemic (Table 3).

\section{CLASS INSECTA}

Within the Class Insecta 21 Orders reported from Christmas Island are treated below. There are no reports from Christmas Island of four orders, namely Archaeognatha (bristletails), Plecoptera (stoneflies), Megaloptera (alderflies), or Mecoptera (scorpion-flies).

\section{Order Zygentoma}

The silverfish (formerly Order Thysanura) are poorly represented on Christmas Island. CSIRO Division of Entomology (1990) collected two (specimens? of) Lepismatidae under bark near North West Point that were not determined to species. James (2007) reported a single representative of Lepismatidae, not determined to species. Humphreys and Eberhard (2001) collected a troglobitic species of Metrinura (Nicoletiidae) considered likely to be a new (and endemic) species (Table 3); this collection represented a range extension of the genus from New Caledonia and eastern Australia.

\section{Order Odonata}

There are no endemic species. One widespread, migratory species of Odonata, Pantala flavescens is common on Christmas Island (Kirby 1900e; CSIRO Division of Entomology 1990). Two other widespread species were reported by Kirby (1900e), but not since.

\section{Order Phasmida}

Only one stick insect species has been recorded on Christmas Island. Kirby (1889) described the phasmid species, Clitumnus stilpnoides, from three specimens in Lister's 1887 collections, with a further four specimens collected by Andrews in 1899-1900 (Kirby 1900f). This species, now Ramulus stilpnoides, is recognised as a distinct species in AFD, ALA and GBIF and the few distributional records in those sources are from Christmas Island only: it is widely accepted as a Christmas Island endemic (CSIRO Division of Entomology 1990; Rudolf and Brock 2017).

No other identified species of phasmids have been reported from Christmas Island. However from Andrews' 1898-99 collection, Kirby (1900f) noted that in addition to $R$. stilpnoides, 'there are two other Phasmidae in Mr. Andrews' collection, apparently belonging to the allied genus Entoria ..., but hardly in sufficiently good condition to describe, though probably new.' We can find no further account of this putative species and assume that the specimens may have represented poorly preserved examples of $R$. stilpnoides.

Rudolf and Brock (2017) considered that $R$. stilpnoides 'has very rarely been reported, except for old records pre-1900, and the only current record of the species is a photo of a live female, which was received in September 2015'. Consequently, it was recognised in 2017 as Vulnerable by the IUCN (Rudolf and Brock, 2017), the only Christmas Island invertebrate species recognised nationally or globally as threatened (Table 1). Its presumed ongoing decline was inferred to be due to predation by black rats and yellow crazy ants (Rudolf and Brock 2017). However, there are many additional records of this species. 'About 30 specimens' were collected in the CSIRO survey of 1989 (CSIRO Division of Entomology 1990). In 2004, it was considered to be widespread but uncommon in forest habitat (Surman 2004), and four voucher specimens were collected (James 2005). 


\section{Order Trichoptera}

The only account of Trichoptera from Christmas Island is from a recent freshwater invertebrate survey by Weeks \& McColl (2011), who reported two undetermined species of caddisflies (Trichoptera; Leptoceridae and Hydroptilidae). They did not assess endemicity.

\section{Order Mantodea}

A single mantid species has been recorded from Christmas Island. From material collected by Andrews in 1897-98, Kirby (1900f) described Hierodula dispar as 'a very distinct species'. However, it was subsequently synonymised with the more widely distributed $H$. patellifera, so it is not endemic to Christmas Island (AFD; ALA; GBIF). About 50 specimens were collected in 1989 (CSIRO Division of Entomology 1990).

\section{Order Ephemeroptera}

The only account of Ephemeroptera from Christmas Island is from a recent freshwater invertebrate survey by Weeks and McColl (2011), who reported at least one undetermined species of mayfly (Ephemeroptera; Caenidae, Tasmanocoenis sp.). They did not assess endemicity, but noted that this species was abundant.

\section{Order Blattodea}

Few species of this order have been collected from Christmas Island. The cockroach fauna was reviewed by Roth (2000), who reported 11 species, of which ten were widespread (described from elsewhere) and one was a cave-dwelling species in a monotypic genus known only from Christmas Island, Metanocticola christmasensis (Roth 1999). Subsequently Humphreys and Eberhard (2001) reported that 'a second troglobitic cockroach of the family Blattellidae also represents an undescribed genus L. Roth, pers. comm. 1998'. However this taxon apparently has not yet been described.

Of the ten non-endemic cockroach species reported from Christmas Island, it is challenging to determine which are native and which are introduced. Two were collected on the island in 1887 before any substantial settlement (Kirby 1889) and another four by Andrews in 1897-98, so these may all be native (Kirby 1900f).

The termite (Isoptera) fauna of Christmas Island is poorly documented. Andrews' collection of 1897-98 included one taxon not determined to species level (Kirby 1900f). From his 1932 collections, Tweedie (1933) added another species, again not determined to species level. Gibson-Hill (1947d) noted three species were present in 1939-40, of which two were identified to genus only and the third not to that level. The CSIRO survey of 1989 collected six termite species identified to genus only (CSIRO Division of Entomology 1990).

\section{Order Embioptera}

There are no endemic species recognised. CSIRO Division of Entomology (1990) collected a single specimen of an adult web-spinner from the Family Oligotomidae. James (2007) recorded two morphospecies identified only to the level of order.

\section{Order Orthoptera}

The Orthoptera fauna is small but poorly surveyed with no recent reviews. CSIRO listed 12 taxa but identified only seven to species level (CSIRO Division of Entomology 1990), and James (2007) listed 18 morpho-species but identified only six to species level. Seven species have been described from the island, all by Kirby (Kirby 1889, 1900f). Of these, Epacromia rufostriata has been synonymised with the more widespread Aiolopus thalassinus (Orthoptera Species File 2018); and Cyrtacanthacris disparilis has been synonymised at species level but remains an endemic subspecies, namely Valanga nigricornis disparilis (GBIF; Table 4), although it is still recognised as a valid species in ALA. The other five species, Ectadoderus flavipalpis (now Ornebius flavipalpis), Gryllacris rufovaria, Phisis listeri (now Paraphisis listeri), Psyra pomona (now Psyrana pomona) and Primnia orientalis (now Nisiocatantops orientalis) are still recognised in at least one of GBIF, ALA or AFD or the Orthoptera Species File (2018) and have not been recorded from elsewhere, so are accepted here as endemic species (Table 2). In addition, two undescribed putative species have been reported that might be endemic Orthoptera species (CSIRO Division of Entomology 1990; Humphreys and Eberhard 2001) (Table 3). Dirsh and Uvarov (1953) created the new monotypic genus Nisiocatantops for Primnia orientalis, and therefore an endemic genus as well.

Ornebius flavipalpis has not been recorded since Andrews collected the types in 1897. Nisiocatantops orientalis was last recorded in 1964 (Campbell 1968), and the other three endemics have been recorded recently (James 2007). None are listed as threatened, nationally or globally.

\section{Order Dermaptera}

Lister's 1887 collection included one species, described by Kirby (1889) as Labidura nigricornis, but this species was later subsumed in the more wideranging Chelisoches morio. From material collected by Andrews in 1897-98, Kirby (1900f) identified eight species, including his previously described $L$. nigricornis, two species described from elsewhere, one taxon identified to genus only and four new species: Labia murrayi, L. incerta, L. indistincta and L. subarmata (now Anisolabis subarmata). Two of these, L. incerta and L. intermedius, were subsequently synonymised with a third, Labia murrayi, now Paralabella murrayi (Steinmann 1989). The 1989 CSIRO survey collected about 130 specimens, comprising six species: of these the wide-ranging Euborellia stali was recorded previously by Kirby (1900f), one other was identified as a wide-ranging species, three to genus only and one only to family level. Neither of the previously described endemic species was recorded. Collections in 2004 reported three morphospecies (James 2005, 2007). 
Paralabella murrayi and Anisolabis subarmata are still recognised as valid species with type localities of Christmas Island and no occurrences elsewhere. Neither species has been recorded since 1897-98, but neither is listed as threatened, nationally nor globally.

\section{Order Zoraptera}

This small order (c. 30 species globally) was not known from Australia until CSIRO Division of Entomology (1990) collected two specimens from leaf litter on Christmas Island that were subsequently described as Zorotypus lawrencei (New 1995). Although it is closely related to several species in Indonesia, it is currently recognised as a valid species (AFD, ALA, GBIF) endemic to Christmas Island (AFD). It has not been recorded since 1989, but is not listed as threatened.

\section{Order Psocodea}

AFD treats the Phthiraptera ('true' lice) and the Psocoptera (barklice and booklice) as higher taxa in the Order Psocodea. There are few reports of the Phthiraptera from Christmas Island. Most bird species carry avian lice of two sub-orders, Amblycera and Ischnocera (Murray et al. 1990). Kirby (1900d) listed a single specimen collected by C.W. Andrews that was large and thought to be from a seabird, but which was not identified beyond 'Mallophaga' (now the Sub-orders Amblycera and Ischnocera). Durham (1908) observed that two Christmas Island flying-foxes Pteropus (melanotus) natalis were infested with a 'louse-like parasite'. The endemic birds of Christmas Island may carry endemic lice, but checklists of lice on Australian birds (e.g. Murray et al. 1990) have provided no specific details for Christmas Island birds.

Surprisingly, there were no documented collections of Psocoptera until Hill and Robertson made small collections in 1983 and the 1989 CSIRO survey collected 177 specimens (CSIRO Division of Entomology, 1990). From these collections Smithers (1995) identified 33 species, from which he described ten new species and two new genera. Although there has been no relevant taxonomic review since, all these species and genera are recognised as valid in AFD, ALA and GBIF, with no records of any beyond Christmas Island. Therefore we treat them as ten endemic species and two endemic genera (Table 2). James (2007) reported 36 morphospecies of Psocoptera collected from 2004 to 2006. They were not examined by a specialist, but it suggests a possibility that the fauna may be larger than currently documented. No species are listed as threatened.

\section{Order Thysanoptera}

There has been little collecting and documentation for this group and no endemic species are recognised. The 1989 CSIRO survey collected 25-30 species of thrips in 21 genera, but none were identified to species level (CSIRO Division of Entomology 1990). James (2007) recorded eight morpho-species identified only to the level of order.

\section{Order Hemiptera}

There has been no comprehensive review of the Hemipteran fauna of Christmas Island. However, Neumann et al. (2016) and Neumann et al. (2018) listed endemic species in some Hemipteran families, as part of a risk assessment for the introduction of parasitoid wasps as a biological control agent for infestations of the introduced yellow crazy ant Anoplolepis gracilipes.

The first collection was of five species by Lister in 1887, all of which were described by Kirby (1889) as new: Lygaeus subrufescens, Oxypleura calypso, Ricania flavicostalis, $R$. affinis and $R$. hyalina. Of these, Neumann et al. (2018) and CSIRO Division of Entomology (1990) recognised O. calypso, Ricania flavicostalis (now Varcia flavicostalis) and $R$. hyalina (now Salona oceanica) as valid endemic species. Ricania affinis (now $V$. affinis) is still recognised as a valid species (GBIF, ALA): although CSIRO Division of Entomology (1990) commented that it is 'shared with Australia', there are no locational records beyond Christmas Island in GBIF or ALA. Lygaeus subrufescens (now Leptocoris subrufescens) is no longer considered endemic, with Göllner-Scheiding (1980) recognising L. s. flava from the Caroline Islands in the Pacific.

Andrews' 1897-98 collections increased the number of known species to 17, with 10 new species described and only two species in the collection having previously been recorded from elsewhere (Kirby 1900a,b). Of the ten species described from this collection, nine are still recognised as valid endemic species: Pentatoma grossepunctatum (now Plautia grossepunctata) (endemicity noted by Cassis and Gross (2002)), Brachyrhynchus lignicolus (now Neuroctenus lignicolus) (endemicity noted by Cassis and Gross (2002)), Ricania flavifrontalis (endemicity noted in ALA), Paurostauria delicata (endemicity noted in ALA, and a monotypic genus), Nogodina subviridis (now Sassula subviridis) (endemicity noted in ALA), Bidis aristella (now Ugyops aristella) (endemicity noted by AFD and Fennah (1964)), Clovia eximia (endemicity noted in ALA and Neumann et al. (2018)), Issus andrewsi (now Distiana andrewsi) (accepted as an endemic species in review by Fennah (1954)) and Idiocerus punctatus (now Batracomorphus punctatus) (endemicity noted in AFD). Andrews' collections were further considered by Distant (1901), who described five more species, of which two are still recognised as valid and endemic species: Nysius spectabilis (with endemicity noted in Malipatil (2010) and Cassis and Gross (2002)) and Lethaeus maculatus (now Elasmolomus maculatus) (with endemicity noted by AFD and Cassis and Gross (2002)). Of the three other species described by Distant (1901) from this collection, Geocoris vestitus was accepted as a valid endemic species by Cassis and Gross (2002) but was synonymised with the more widespread G. jucundus by Kondorosy (2016); Pamera insignis (now Paraeucosmetus insignis) was considered as a valid endemic species by Cassis and Gross (2002) 
but Chandra and Kushwaha (2014) considered that it occurred more widely (to India); and Pamera andrewsi was subsequently synonymised with the wide-ranging Remaudiereana nigriceps (ALA).

The next collection was made by F. Harms in 1933, with this documented by Izzard (1933), who also reviewed the previous published studies of the island's Hemipteran fauna. Izzard (1933) described a further ten species, and Harms' collection brought the tally of Hemipterans recorded from Christmas Island to 56 species, of which 28 were then considered endemic. Of the species described by Izzard (1933), seven are still recognised as valid endemic species: Lygis aldrichi (now Tayloriligus aldrichi) (ALA, GBIF), Lygis murrayi (now Tayloriligus murrayi) (ALA, GBIF), Cylapofulvius listeri (now Peritropis listeri) (ALA, GBIF, and recognised as a valid endemic species by Cassis and Gross (1995)), Laccocoris montandoni (ALA, GBIF), Andrewsiella oceanica (ALA, GBIF, constituting a monotypic genus), Delphacodes muirianus (ALA, GBIF) and Erythroneura harmsi (ALA, GBIF). Nearly 40 years after being collected by Harms, Hishimonus festivus was described from that material by Knight (1970), but there have been subsequent records from west Java (Fletcher and Dai 2013).

In 1964, a CSIRO survey of invertebrates of potential health and agricultural concern resulted in collection of several previously-unrecorded, but widespread, Hemipteran species presumed to have been introduced to Christmas Island (Campbell 1968). The more comprehensive CSIRO survey of 1989 collected about 5600 Hemipteran specimens categorised into about 140 morpho-species, with most not named (CSIRO Division of Entomology 1990). However, about 20 wideranging and probably introduced species were recorded for the first time, and the collection documented the continued presence of nine previously-described species recognised as endemic to Christmas Island. In a targeted and comprehensive survey of scale insects (Coccoidea) on the island, Neumann et al. (2016) recorded 28 species, none of which were endemic, and most of which were probably recent introductions.

Two further species have been described from Christmas Island: Matigocoris insularis by Kormilev (1983), which was still accepted as a valid endemic species by Cassis and Gross (2002); and Oliarus trispiralis by Löcker et al. (2006).

Twenty-four Hemipteran species are recognised as endemic to Christmas Island (Table 2), of which three have not been recorded since 1897-98, four not since 1933 and four not since 1964. No species are listed as threatened on global or national lists.

\section{Order Neuroptera}

The Order Neuroptera (including lacewings and antlions) is poorly studied on Christmas Island, with six species identified to date (New 1991). C.W. Andrews collected two species that were described as new by Kirby (1900e). Formicaleo morpheus has since been dissolved under Distoleon somnolentus (New 1991) (Table 4), whereas Myrmeleon iridescens is still recognised as a valid species (New 1991), endemic to Christmas Island (AFD). The CSIRO 1989 collection contained six taxa, five wide-ranging species and one probably undescribed species (Malada sp. nov.; Table 3), but not Myrmeleon iridescens (CSIRO Division of Entomology 1990; New 1991). James (2007) recorded 13 morpho-species of winged adults (not identified beyond order), mostly collected in light-traps.

Myrmeleon iridescens was described from a single specimen collected in 1897-98, and has not been recorded again, but it is not listed as threatened.

\section{Order Coleoptera}

Many beetles have been described from Christmas Island, and most are still recognised as endemic, but there has been no detailed review. As with many other taxonomic groups, the most important collections were by Maclear in 1887 (Waterhouse 1887), Lister in 1887 (Gahan 1889), Andrews in 1898-99 (Waterhouse et al. 1900), Tweedie in 1932 (Tweedie 1933) and CSIRO in 1989 (CSIRO Division of Entomology 1990), with very limited other occasional collecting.

From 'several specimens' of beetles collected by Maclear, Waterhouse (1887) described two species, Chrysodema simplex and Piezonotus discoidalis (subsequently transferred to the endemic genus Rhyncholobus), both of which are still recognised as valid species. Rhyncholobus discoidalis has no records other than from Christmas Island (ALA, GBIF). However, C. simplex was subsequently reported from Cocos (Keeling) islands by Gibson-Hill (1950), but it is likely that this represented an importation from Christmas Island, with 'teak' Berrya trees.

Lister's collection comprised about 70 specimens representing about 20 species, with 10 not identified to species and four described as new by Gahan (1889): Paraegus listeri (now Aegus listeri), Ceresium nigrum, Monohammus nativitatis (now Acalolepta nativitatis) and Praonetha perplexa (now Pterolophia perplexa). All are still recognised as valid species, and only one of these has since been recorded beyond Christmas Island (AFD, ALA, GBIF): the exception is A. nativitatis, which was also reported from Cocos (Keeling) islands by Gibson-Hill (1950), probably with importation from Christmas Island of soil and timber, as for C. simplex. Slipinski and Escalona (2016) also recognised Ceresium nigrum as a valid endemic species.

Andrews' 1897-98 collection was appreciably larger, comprising 93 species, of which 12 were determined only to genus, six were the species previously described from Christmas Island, 25 were attributed to species described from elsewhere and an impressive 50 were newly described (Waterhouse et al. 1900). Of those 50 species, at least 35 are still recognised as valid species in both ALA and GBIF (unless stated otherwise below) and have never been recorded other than for Christmas Island: Apatenia apicalis, Litocerus jordani (recognised 
in GBIF), Xenocerus nativitatis (GBIF), Paranobium posticum (now Clada posticum) (ALA), Neoptinus parvus (with endemicity noted by Belles and Lawrence (1990)), Bothrideres strigatus (now Ascetoderes strigatus) (ALA), Orychodes andrewsi, Chrysobothris andrewsi (GBIF), Ceresium quadrimaculatus (with endemicity noted by Slipinski and Escalona (2016)), Examnes affinis (now Ceresium affnis, with endemicity noted by Slipinski and Escalona (2016)), Aegocidnus exiguus (now Sciades exigua), Prinobius coxalis (now Anomophysis coxalis), Olenecamptus basalis, Rhyparida modesta, Rhyparida rossi, Cossonus variipennis, Pachyops incertus, Phloeophagosoma dubium (now Rhyncholosoma dubium), Camptorhinus crinipes, Acicnemis andrewsi, Rhyncholobus andrewsi, Rhyncholobus rossi, Rhyncholobus vittatus, Dryophthorus assimilis, Tetrigus murrayi, Anchastus discoidalis, Megapenthese andrewsi, Hololepta malleata, Platysoma lignarium (now Platylister lignarium), Figulus rossi (with endemicity noted by Monte et al. (2016)), with a possible record from Cocos (Keeling) islands (Gibson-Hill 1950; Cassis et al. 1992) likely to be a result of introductions from Christmas Island), Laius tibialis (with endemicity noted by Liu et al. (2015)), Shoguna striata (ALA), Protaetia andrewsi (noted as 'known only from type locality' in AFD), Phileurus convexus (now Eophileurus convexus) and Oniscomorpha marmorata (now Leperina marmorata, per ALA and noted as a valid species endemic to Christmas Island by Kolibáč (2013)). Although there are putative unpublished records for Apomecyna nigritarsis from Java (http://www.cerambycoidea.com/forum/topic. asp?TOPIC_ID=14880), ALA and GBIF recognise the species as valid and include no records from beyond Christmas Island.

We could find no documentation in GBIF or ALA for several other species described from Christmas Island by Waterhouse et al. (1900), but consider them as valid and endemic (Table 2). Epliachna nativitatis (now Henosepilachna nativitatis) is recognised as a valid species restricted to Christmas Island by Jadwiszczak and Wegrzynowicz (2003); Paederus listeri is retained as a valid species by Frank (1988); Bradymerus seminitidus is retained as a valid species endemic to Christmas Island by Schawaller (2006); Amarygmus funebris is retained as a valid species endemic to Christmas Island by Bremer (2007); Opatrum dubium (now Gonocephalum dubium) is retained as a valid species endemic to Christmas Island by Iwan et al. (2010). Demotina lateralis, Toxicum antilope, Sessinia andrewsi and Nyctobates carbonaria (as Promethis carbonaria) were recognised as valid species and collected by CSIRO Division of Entomology (1990), although a global review of Toxicum did not list antilope (Doyen et al. 1989). CSIRO Division of Entomology (1990) also recognised as valid species, but did not collect, Psylliodes tenuepunctata and Sessinia listeri.

We consider the remaining species described by Waterhouse et al. (1900) as no longer valid or not endemic to Christmas Island. Rhabdocnemis fausti is subsumed in the more wide-ranging $R$. obscurus in ALA; Stelidota orientalis is subsumed in the more wideranging Omosita nigrovaria (GBIF, ALA); and Shoguna polita is lumped in the more wide-ranging Shoguna termitiformis (ALA, GBIF).

After Andrews' 1897-98 collections, the next published report on beetles was a brief account of a small collection made by Tweedie in 1932 (Tweedie 1933). This comprised 28 species, of which 18 had been described previously from Christmas Island, seven had been described from elsewhere, two were not determined to species, and one, Phelipara subvittata (Cerambycidae), was newly described. It is still recognised as a valid species with no known records beyond Christmas Island.

The entomological survey by CSIRO in 1989 dwarfed all previous survey efforts for beetles, collecting 'about 10,000' specimens representing 350 species' (CSIRO Division of Entomology 1990). This sampling included representation of 77 of the c. 90 species recorded in the 1897-98 sampling (Waterhouse et al. 1900), and with other previously-unpublished minor samples brought the known tally of beetles on the island to 390 species. CSIRO Division of Entomology (1990) also reported that 14 species collected in the 1897-98 sampling (Waterhouse et al. 1900) were not collected in 1989 and that 'most of these are moderate-sized insects ... that would not be overlooked in general collecting and may no longer occur on the island: however, given the small amount of time devoted to surveying the fauna, sampling error is more likely'. About 37 of the species collected in 1989 had been described earlier from Christmas Island, and about 59 had been described from elsewhere. Most (253) of the beetle species collected during the 1989 survey were diagnosed only to genus, and to our knowledge most of these collections have not subsequently been described or identified to species. However, there are some exceptions, with material collected in the CSIRO survey of Christmas Island used as the basis for the description of the endemic Psammorpha lawrencei by Stebnicka (1994) (a blind and flightless species, constituting a monotypic genus, considered endemic to the island: Stebnicka and Howden (1996)), Paratrichapus christmasensis (SouzaGonçalves et al. 2019) and Cephennomicrus lawrencei (Jałoszyński 2017).

The only subsequent notable collection from Christmas Island is of a single 'remarkable' beetle collected from a cave in 2006, and described as Lymnastis brooksi (Carabiidae) by Baehr (2008).

Table 2 lists 58 beetle species that we consider are valid species reported only from Christmas Island. Given that the CSIRO collection of 1989 also reported 253 undetermined species, it is highly likely that the actual number of endemics is appreciably higher than the 58 listed in Table 2. Rhyncholobus is an endemic genus of large and brightly coloured weevils containing four species, and it represents the most likely example of autochthonous radiation to have occurred on Christmas Island. Ten of the endemic species have not been 
reported since 1897-98 (Table 5). Notwithstanding these long periods without records, none of the endemic beetle species is listed as threatened.

\section{Order Strepsiptera}

There are no endemic species recognised, and only a single individual has been collected, in 1989. This was a single specimen of stylops parasitising a delphacid hemipteran, deduced to be in either Halictophagidae or Elenchidae (CSIRO Division of Entomology 1990).

\section{Order Diptera}

The Diptera fauna of Christmas Island has been far from comprehensively documented. Andrews collected between 30 and 40 species in 1898-99, but noted that these 'unfortunately have not yet been determined'. We can find no record of any subsequent substantial collecting until 90 years later, when CSIRO collected about 5000 specimens, 'but only a few complete identifications could be made' (CSIRO Division of Entomology 1990). These were sorted to about 185 morpho-species, but only 22 of these were determined to species level and 63 to genus. The fauna now includes many introduced human-commensal pests such as house flies, fruit flies and mosquitoes (Campbell 1968; CSIRO Division of Entomology 1990).

Nine species of Diptera have been described from Christmas Island between 1889 and 1994 and eight of these are considered endemic species (Table 2). Laphria nigrocaerulea (Kirby, 1889) is a junior homonym of Laphria nigrocaerulea (van der Wulp 1872) from New Guinea, so was renamed Orthogonis christmasensis by Daniels (2012); it is considered valid and endemic (ALA, AFD, GBIF) and is still abundant (DJ pers. obs.). The marine tipulid flies Cymatopus calcaratus and Cymatopus longipilus were described by Parent (1935) from a collection by Harms in 1933: the most recent review of the genus considered both to be still valid and endemic to Christmas Island (Evenhuis 2005). The flower fly Syritta maritima was described by Hull (1944), also from Harms' 1933 collection, and the most recent review of the genus concluded that it is still regarded as a valid species endemic to Christmas Island (Lyneborg and Barkemeyer 2005). Thompson (2014) reviewed the family Syrphidae on Christmas Island, and concluded that Syritta maritima was the only endemic species among seven reported species, but considered it may be extinct, with no records since the original collection in 1933. The 'remarkable' Poecilosomella pectiniterga was described by Deeming (1964) with its holotype from Andrews' 1897 collection and other material from Biak Island, with subsequent records from other locations. However, the most recent review split the species and, as redefined, considered that Poecilosomella pectiniterga is restricted to Christmas Island (Hayashi 1997). Micrepimera punctipennis described from a specimen collected on Christmas Island in 1983 by Matile (1990) is still recognised as a valid species with no records beyond Christmas Island (GBIF). When described it comprised a monotypic genus, but other species in the genus have been described subsequently (Ševčík and Papp 2011).
Stilbomyia juncunda (now Hemipyrellia jucunda) (Kirby 1889) is recognised as a valid species in GBIF (but not ALA or AFD) with no records from elsewhere. It was last collected by CSIRO in 1964 (Campbell 1968), and was explicitly noted as not collected (notwithstanding a large collection of dipterans) by CSIRO in 1989 (CSIRO Division of Entomology 1990). Lissocephala powelli described from Christmas Island by Carson and Wheeler (1973) is recognised as a valid species in GBIF (but not ALA or AFD) with no records from elsewhere. There are many recent records of Lissocephala powelli on its host crabs (Orchard 2012). Amblypsilopus natalis, described by Bickel (1994) from material collected by CSIRO in 1989, is recognised as a valid species endemic to Christmas Island in ALA, AFD and GBIF. The mosquito Aedes andrewsi (Edwards 1927) has been recorded from Indonesia and Australia (GBIF), and is not recognised by ALA or AFD, so is not accepted here (Table 4).

None of the endemic dipteran species is listed as threatened, nationally or globally.

\section{Order Siphonaptera}

The last specimens of the endemic Maclear's rat Rattus macleari were collected by Durham in 1902 (Durham 1908; Pickering and Norris 1996; Green 2014). Fleas collected from these specimens were described as a new species, Xenopsylla nesiotes (Jordan and Rothschild 1908). The species is accepted by AFD, ALA and GBIF with no records beyond Christmas Island. Maclear's rat was the only known host for the flea, so the flea almost certainly became extinct, unceremoniously, when the rat did (Kwak 2018), between 1902 and 1907, shortly before it was described by science. Maclear's rat is listed as extinct nationally and globally, but its host-specific flea is not formally listed as extinct nationally or globally.

\section{Order Lepidoptera}

The first collection of Christmas Island butterflies, by Maclear in 1887, was largely destroyed in transit, but two specimens were intact and both were named as new species by Butler (1887): Vadebra macleari and Terias amplexa. In 1887, Lister collected five species including the two previously described Christmas Island species, a new species (Hypolimnas listeri) and two previously described from elsewhere (Butler 1889). Andrews collected another four species in 1897-98, with one of these described as a new species by Butler (1900): Charaxes andrewsi. No butterflies have been described from the island subsequently, although other more wide-ranging species (including some visitors) have been added to the species complement (GibsonHill 1947e; Moulds and Lachlan 1987; Johnson and Wilson 2018), which now numbers 29 species (Johnson and Wilson 2018).

Of the four butterfly species for which Christmas Island is the type locality, only one, Charaxes andrewsi, is still regarded as a valid species endemic to Christmas Island (e.g. ALA) (Table 2), although it has at times been considered a subspecies of Eriboea pyrrhus (Pendlebury 
1933; Gibson-Hill 1947e). The three other butterfly taxa have had a buffeted taxonomic history. Terias amplexa was relegated to a subspecies of Eurema hecabe by Corbet and Pendlebury (1932), with this treatment followed by Pendlebury (1933) and Gibson-Hill (1947e), but treated as a distinct species by Moulds and Lachlan (1987), then reduced to a subspecies of Eurema alitha by Yata (1995), a treatment followed by ALA. Vadebra macleari is still accepted by GBIF but synonymised with the more wide-ranging Euploea climena in ALA; and Hypolimnas listeri is synonymised with the more wideranging $H$. bolina (e.g. in GBIF) (Table 4).

In contrast to the relatively small and reasonably well resolved butterfly fauna, the moth fauna of Christmas Island is large and very inadequately catalogued, and there has been no recent comprehensive review. Lister's collection in 1887 included five species (Butler, 1889), of which two were described as new (Eudragana limbata - with a new genus established for it, although this was soon subsumed in Bocula (Hampson 1900) - and Pyralis listeri), and one taxon (Hydrillodes sp. nov.) considered 'probably a new species' but with insufficient material to describe it (Butler 1889). Andrews' collection of 1897-98 was much more extensive, comprising 74 species comprehensively documented by Hampson (1900) and Walsingham (1900). In characterising this material, Hampson (1900) noted that 'the distribution of Christmas Island moths seems to show very clearly that it has no connection with the Malayan sub-region'. The collection included all five species previously recorded by Butler (1889) and 54 species previously described from elsewhere. It also included 15 new species: Mimeusemia econia, Hydrillodes vexillefera (with the description noting also records from beyond Christmas Island), Erastria griseomixta, Porthesia pulverea, Boarmia scotezonea, Ephestia scotella, Zinckenia nigerrimalis, Glyphodes (Phacellura) holophaealis (all described by Hampson (1900)) and Cosmoclostis quadriquadra, Brenthia elachista, Simaethis ornaticornis, Tortricomorpha chlorolepis, Epagoge halysideta, Caenognosis incisa (in a newly established genus), and Dendroneura punctata (all described by Walsingham (1900)). Two of Andrews' specimens were attributed by Walsingham (1900) to the African species Phycodes adjectella, but these have subsequently been described by Kallies (2013) as the Christmas Island endemic Nigilgia browni, with further specimens collected recently (C. Pink pers. comm.).

A further eight originally unsorted specimens from Andrews' collection were described, with Christmas Island as the type locality, over the next two decades in more miscellaneous taxonomic reviews: Thalassodes subviridis by Warren (1905), Maliattha phaeozona and Amyna crocosticta by Hampson (1910), Armactica andrewsi and Earias latimargo by Hampson (1912), Comostolopsis regina by Thierry-Mieg (1915), Scopula tumiditibia by Prout (1920), and Anomis esocampta by Hampson (1926). A further description of a Christmas Island endemic moth from Andrews' original collection - of Acontia sollemnis - was made more than 100 years after the initial collection, by Hacker and Holloway (in Hacker et al. 2008).

The next substantial collection was of 42 specimens from nine species of geometrid moths collected by Tweedie in August-September 1932 and documented by Prout (1933), who described five new species: Hemithea (Chlorissa) hyperymna ('a charming little species'), Anisodes hypomion, Ecliptopera phaula, Sauris pelagitis [previously collected and identified by Hampson as the more wide-ranging $S$. hirudinata] and Syrrhodia vindex [previously collected and identified by Hampson as the more wide-ranging Hyperythra lutea]. Prout also felt 'reluctantly compelled to leave ... unnamed a distinct Scopula species that Hampson had earlier listed as an undetermined Craspedia species'.

A more substantial collection (of about 1740 moth specimens) was gathered by Gibson-Hill in 1939-40 that nominally included representation of 174 species, but the description of this collection reported only on 74 of these species, noting that 'it is regrettable that the study of the collection cannot be completed now, but the limitations imposed as a result of the war render this impossible' (Pendlebury 1947): probably as a consequence of that interruption, and his death in 1943, no new species were described from this collection.

CSIRO's collection of Lepidoptera in 1990 included about 900 specimens representing about 185 species (of which about 16 were butterflies), with species attributions not made for most moths (CSIRO Division of Entomology, 1990). This collection included nine species previously described as endemic (Zinckenia nigerrimalis (as Spoladea nigerrimalis), Glyphodes (Phacellura) holophaealis (as Diaphania holophaealis), Thalassodes subviridis, Comostolopsis regina, Anisodes hypomion, Maliattha phaeozona, Amyna crocosticta, Earias latimargo and Armactica andrewsi. However, most of the collection was sorted to family or genus level only. CSIRO Division of Entomology (1990) also noted that $22 \%$ of the 185 species were represented in their collection by only single individuals, and interpreted this to mean that much of the fauna remained uncollected, most likely including more species of endemics. From 2004 to 2006, James (2007) collected 141 morphospecies of moths, but only five of these were identified to named species.

Of the 32 moth species described from Christmas Island, the status (whether or not still considered a valid species, and whether or not reported subsequently away from Christmas Island) of many is unclear. Here, we consider 24 as endemic (Table 2). Nineteen of these are regarded as valid species in GBIF with no records beyond Christmas Island: Ephestia scotella, Ruttelerona scotozonea (= Boarmia scotezonea), Hymenia nigerrimalis (= Zinckenia nigerrimalis), Cosmoclostis quadriquadra, Brenthia elachista, Moca chlorolepis (= Tortricomorpha chlorolepis), Opogona punctata (= Dendroneura punctata), Thalassodes subviridis (= Pelagodes subviridis), Armactica andrewsi, Bocula limbata, Earias latimargo, Comostolopsis regina, Scopula tumiditibia (with endemicity noted 
by Sihvonen (2005), Loboschiza halysideta, Nigilgia browni, Hemithea hyperymna, Anisodes hypomion, Ecliptopera phaula and Sauris pelagitis. One is listed as a valid (though 'doubtful') species in GBIF, with no records beyond Christmas Island: Lithacodia griseomixta (= Erastria griseomixta). Three are not listed in GBIF but recognised elsewhere as valid and without records beyond Christmas Island: Diaphania holophaealis (http://globiz.pyraloidea.org), Choreutis ornaticornis (= Simaethis ornaticornis) (http://choreutidae.myspecies. info/taxonomy/term/66) and Amyna crocosticta (http:// www.nic.funet.fi/pub/sci/bio/life/insecta/lepidoptera/ ditrysia/noctuoidea/noctuidae/acontiinae/amyna/index. html). The recently described Acontia sollemnis has not been reported from elsewhere (Hacker et al. 2008).

Five of the 25 accepted endemic lepidopteran species have not been reported since 1897-98 and a further six not since 1939 (Table 2). Notwithstanding these long periods without records, none of the endemic lepidopteran species is listed as threatened, either nationally or globally.

\section{Order Hymenoptera}

A comprehensive recent review, based on intensive and extensive field surveys and a re-appraisal of historic records listed 52 species of ants from the island (Framenau and Thomas 2008). None of these is considered endemic. Most of the ant species reported from the island are introduced (Framenau and Thomas 2008). Christmas Island is the type locality for three ant species - Camponotus melichlorus, Leptogyne harmsi and Pachycondyla christmasi (Kirby 1889; Donisthorpe 1935), but all three species are now known to also occur naturally in other areas (Framenau and Thomas 2008). The number of native species is indeterminate, but only two (presumed native, but not endemic) ant species were recorded immediately before and after the island's first settlement (Kirby 1889; Andrews 1900c).

There has never been a comprehensive treatment of the bees and wasps of Christmas Island. Collecting commenced pre-settlement with J.J. Lister in 1887 with two species (Euodynerus polyphemus and Polistes (Gyrostoma) balder) from this collection described by Kirby (1889). Five further species (Homalictus andrewsi, Patellapis (Pachyhalictus) binghami, Ophion flavocephalus (now Enicospilus flavocephalus), Megachile nivescens, Megachile rotundipennis) were described from Andrews' 1897-98 collections (Kirby 1900c), and another (Lithurgus andrewsi) from the same collection was described by Cockerell (1909). Other than Enicospilus flavocephalus, all of these species are still regarded as valid and endemic to Christmas Island (e.g. Walker 1997).

Carl Gibson-Hill collected further specimens in 1939-40, but most were not subsequently worked over; however two species were described from this material about 50 years later. Bouček (1988) described Sirovena stigma, originally considered to comprise a monotypic genus until Li et al. (2013) added another species, from China. Zettel (1990) described Phanerotoma pacifica from Gibson-Hill's collection, although its specific name indicates confusion with the other Christmas Island in the Pacific.

Campbell (1968) recorded 11 non-ant hymenoptera in a survey focussed on insects of medical, veterinary, agricultural and forestry significance, but notably did not list the honey bee Apis mellifera, dating its likely introduction to the island to sometime during the next 20 years to 1989, when ANIC-CSIRO collected about 2700 specimens representing 299 species (CSIRO Division of Entomology 1990). Eight taxa were named to species, 105 to genus, and 190 as unnamed genera (CSIRO Division of Entomology 1990). These collections have scarcely been worked upon, having yielded just five additional species records for the island, and five species new to science, including three endemics: Dendrosotinus insularis (Belokobylskij et al. 2004), Neoheterospilus insularis (known from a single specimen: Belokobylskij (2006)) and Oxyscelio caesitas (Burks et al. 2013).

James (2007) reported 68 morpho-species of wasps collected by Parks Australia in 2004 to 2006, but identified only Polistes balder to species level. More recently, a large collection of parasitoid wasps was made by the CESAR Consulting Group (Weeks 2013) as part of their assessment of the potential non-target impacts of fipronil insecticide that has been used to control yellow crazy ants across the island. Using yellow sticky traps in 2012, they collected 3,390 specimens of parasitoids in 19 families. None were identified to genus or species. Three parasitoid species were identified from the island as part of the research program supporting the indirect biological control of the yellow crazy ant (Green et al. 2014), but these are not regarded as native to the island.

The total list of species of non-ant hymenoptera stands at 34, 12 of which we regard as endemics (Table 2). However it is clear that given the great diversity of non-ant Hymenoptera on Christmas Island especially amongst the wasps, and the relative paucity of named species in the ANIC-CSIRO, Parks Australia and CESAR collections, there are likely to be more endemics on the island.

Our list of endemics includes two large predatory wasp species (Vespidae) that also occur in the Cocos (Keeling) Islands, $900 \mathrm{~km}$ further west. Polistes balder Kirby was listed by Richards (1978) as occurring there, and he refers to a specimen in the BMNH but does not give details. We cannot find this record, so do not know the collection date. These wasps are large and aggressive and build conspicuous paper nests, but the species was not recorded from the islands by Darwin (1845), Wood Jones (1909) or Gibson-Hill (1950). Gibson-Hill especially was unlikely to have overlooked this species during his extensive sampling, so we conclude this species must have been introduced there from Christmas Island more recently. Gibson-Hill (1950) gives a good account of how insects might have been transported from Christmas Island to the Cocos (Keeling) Islands, in this case perhaps as a nest attached to some structure and transported on a ship. Eudynerus polyphemus Kirby was mentioned by CSIRO Division of Entomology (1990) as being known from 
Home Island in the Cocos (Keeling) islands group, but gave no further detail. Similar to $P$. balder, this is a large and conspicuous species that often builds its mud nests on buildings, but was not recorded by earlier naturalists. The same reasoning holds - we conclude it was introduced to the Cocos (Keeling) Islands from Christmas Island.

Of the 12 recognised endemic species, eight have been collected relatively recently as part of the 1989 ANIC/CSIRO collections, with Lithurgus andrewsi being a possible but unconfirmed ninth species (CSIRO Division of Entomology 1990). Both species of Megachile were collected by Campbell in 1968, but only single specimens were collected in 1989 and 2004 and these were not determined to species level. Finally, the endemic halictid Patellapis (Pachyhalictus) binghami has not been collected since Campbell in 1968. Walker (1997) noted that Josephine Cardale, the CSIRO hymenoptera specialist on the 1989 expedition, was not able to collect this halictid despite considerable dedicated effort, and he speculated that it might be extinct.

\section{Phylum ECHINODERMATA}

Marsh (2000) reviewed the Echinodermata (including four collections by the Western Australian Museum) and provided a list of 67 species across the five Classes. She considered that this list was probably not complete but contained the majority of species present. Tan et al. (2014b) added a further six species from a limited survey of submarine caves. The echinoderm fauna is relatively depauperate, probably owing to a combination of the island's small size, relative isolation and limited diversity of marine habitats (Marsh 2000). No species are considered endemic to Christmas Island. One species of crinoid, Comissia pectinifer (now Alloeocomatella pectinifera), was described from the island by Clark (1911), but it has since been found to be more widespread (GBIF; Table 4).

\section{Phylum HEMICHORDATA}

Tan et al. (2014b) recorded one species from submarine caves, but identified it only to the Class Enteropneusta.

\section{Phylum CHORDATA}

The classes of the Subphylum Vertebrata are treated separately below. The only other chordates reported are salps and doliolids (Tunicata: Thaliacea), which are a common element of the inshore plankton (Davies and Beckley 2010).

\section{CLASS PISCES}

The fish fauna in waters of and around Christmas Island has now been well sampled. Early collections were limited: for example, Andrews (1900c) collected only 21 species. The inventory increased substantially with targeted sampling from the 1960s. By 2007, 592 species were recorded (Allen et al. 2007), with a recent comprehensive review extending this to 681 species (Hobbs et al. 2014b). Only five of these species occur in the island's freshwater systems, three of which are introduced and two of which are native but occur widely beyond the island (Hobbs et al. 2014b). Allen et al. (2007) considered four marine fish species to be endemic to Christmas Island: Pseudochromis viridis, Praealticus natalis, Eviota natalis and Aseraggodes crypticus. The text of Hobbs et al. (2014b) corroborates that these are the four endemic fish species, but their accompanying checklist (Hobbs et al. 2014b, Table 1) also reports two additional recently-described species as endemic, and known only from their holotypes: Microbrotula andersoni, collected in 1978 (Schwarzhans and Nielsen 2011) and Paradiancistrus christmasensis, collected in 1986 (Schwarzhans and Møller 2011). Another species, Steeneichthys nativitatis, described in 1987 from Christmas Island, is now known to be more widespread (Allen et al. 2007). GBIF and ALA recognise as valid species all of the six endemics reported by Hobbs et al. (2014b), but both databases also have records of Praealticus natalis from well beyond Christmas Island, extending at least to Guam: so we do not consider it as a Christmas Island endemic here.

All of the five endemic fish species have been recorded recently, and none is listed globally or nationally as threatened.

\section{CLASS AMPHIBIA}

There are no native or established amphibians on Christmas Island. Two species have been intercepted in cargo shipments on rare occasions (Parks Australia, unpublished data): Duttaphrynus melanostictus (Bufonidae) and Litoria adelaidensis (Hylidae) (DJ, pers. obs.).

\section{CLASS REPTILIA}

The Christmas Island native terrestrial reptile fauna comprises five lizard species and one blind-snake. The taxonomic treatment of some of the lizard species has been unstable (Boulenger 1887, 1889; Smith 1929), but authorities consistently now recognise Cyrtodactylus sadleiri, Lepidodactylus listeri, Cryptoblepharus egeriae and Emoia nativitatis as endemic (Cogger and Sadlier 1981; Cogger 2014), as well as the blind-snake Ramphotyphlops exocoeti. All are species recognised by GBIF, and all locational data in GBIF for these species are from Christmas Island. The only other native species is generally considered to be the wide-ranging Emoia atrocostata (Cogger and Sadlier 1981; Cogger et al. 1983; Brown 1991), but may merit closer taxonomic scrutiny. Recent analyses demonstrate that Lepidodactylus listeri, Cryptoblepharus egeriae and Emoia nativitatis are of remarkable antiquity, separated from their closest sampled relatives for 5-20 million years (Oliver et al. 2018).

All five endemic reptile species are considered threatened at global and national levels (Table 1), having exhibited severe and rapid decline since the 1980s (Smith et al. 2012; Andrew et al. 2018). Emoia nativitatis is now extinct, and Lepidodactylus listeri and Cryptoblepharus egeriae are extinct in the wild. The Christmas Island population of Emoia atrocostata was also extirpated over this period (Andrew et al. 2018). 


\section{CLASS AVES}

The birds of Christmas Island have been well-studied with several reviews, the most recent being James and McAllan (2014). At the time of colonisation there were eight seabird and eight landbird species breeding, but that had increased to nine and 14 species respectively by 1982, due to both colonisation and introduction (Stokes 1988). Four of the seabirds and seven of the landbirds are endemic taxa, but not all are full species. A further complication is that the seabird taxa disperse widely as a routine part of their life histories. Six species are considered endemic (Table 2).

Of the landbirds, the Christmas Island imperial pigeon Ducula whartoni, Christmas Island swiftlet Collacalia natalis, Christmas Island hawk-owl Ninox natalis and Christmas Island white-eye Zosterops natalis were each described as full species (Sharpe 1887; Lister 1889). The Zosterops is the only one to be universally treated as a full species ever since. However, because it has a small, introduced subpopulation in the Cocos (Keeling) Islands (Woinarski et al. 2014), we characterise it here as an 'original endemic'. The three other species were subsumed as subspecies of Wallacean congeners by Chasen (1933a) and Chasen (1935), and this was followed internationally, for example by Peters (1940) and locally by Gibson-Hill (1947g). Ducula whartoni was briefly considered to be a subspecies of Ducula rosacea, but otherwise has been regarded as full species by recent authorities (e.g. Christidis and Boles 2008) and is treated as such by ALA and GBIF. Ninox natalis was listed as a subspecies of $N$. forbesi and then $N$. squamipila, before being elevated to a full species again by Norman et al. (1998). Since Chasen (1933a), Collacalia natalis has usually been treated as a subspecies of Collacalia esculenta (e.g. ALA, AFD, GBIF), but also Collacalia linchi (e.g. Christidis and Boles 2008). A recent study integrating molecular and morphological data justified its full species status (Rheindt et al. 2017), which has been adopted by GBIF.

As with Zosterops natalis, attempts were made by the Clunies Ross family to translocate populations of Ducula whartoni, and also the endemic subspecies of island thrush Turdus poliocephalus erythropleurus from Christmas Island to islands in the Cocos (Keeling) group (Gibson-Hill 1949a), but the pigeon and thrush introductions ultimately failed (Stokes et al. 1984).

The type specimen of Abbott's booby Papasula abbotti was collected on Assumption Island in 1893 where it probably bred. Evidence (mostly from subfossils) indicates that prehistorically it bred widely in the tropical IndoPacific (James and McAllan 2014). It now breeds only on Christmas Island. The Christmas Island frigatebird Fregata andrewsi was described as a full species, and that has never been challenged. Both of these seabirds are breeding endemic species that disperse widely when feeding or not breeding (James and McAllan 2014).

There are also five endemic subspecies of birds. Three taxa conventionally regarded as subspecies are: 'golden' white-tailed tropicbird Phaethon lepturus fulvus (though it has no type locality); Christmas Island emerald dove Chalcophaps indica natalis; and Christmas Island thrush Turdus poliocephalus erythropleurus. The Christmas Island goshawk Accipiter hiogaster natalis is sometimes treated as a full species (e.g. James and McAllan 2014). A fifth endemic subspecies, Fregata minor listeri, is widely overlooked due to a nomenclatural error (see James and McAllan 2014), so further taxonomic review is warranted.

Above species level, there is one endemic genus of birds, Papasula (Olson and Warheit 1988), which is monotypic.

Conservation-wise, the birds have fared well compared with the other vertebrate groups, with no extinctions despite some declines (Garnett et al. 2011; James and McAllan 2014). All endemic taxa are recorded regularly (James and McAllan 2014); nonetheless, 11 endemic bird taxa are listed as threatened, that being three species globally, and seven species and four subspecies nationally (Table 1).

\section{CLASS MAMMALIA}

Collections around the time of the island's settlement reported five terrestrial native mammal species (two rodents, two bats and a shrew) from Christmas Island. Rattus nativitatis and $R$. macleari have been consistently accepted as valid species and endemic (Thomas 1887, 1889; Andrews 1900b; Jackson and Groves 2015). The shrew has had a mercurial taxonomic history, but the most recent review confirmed its status as an endemic species Crocidura trichura (Eldridge et al. 2014), and this is conventionally accepted (Jackson and Groves 2015). The island's only insectivorous bat was described as an endemic species, Pipistrellus murrayi by (Andrews 1900b), but was subsequently subsumed within the more wide-ranging $P$. tenuis (Koopman 1973). This treatment is no longer accepted, and $P$. murrayi is now universally accepted as a valid species endemic to Christmas Island (Jackson and Groves 2015). The island's flying-fox was described as an endemic species, Pteropus natalis by Thomas (1887), but reduced to an endemic subspecies of the more widespread $P$. melanotus by Chasen (1940). This conclusion has been accepted by some but not all subsequent accounts, with a recent analysis remaining equivocal (Phalen et al. 2017). The most recent taxonomic review of Australian mammals accepted it as a valid species endemic to Christmas Island (Jackson and Groves, 2015), but noted a need for further taxonomic assessment. Hence, the terrestrial native mammal species of Christmas Island comprise either five endemic species, or four endemic species and one endemic subspecies.

The Christmas Island mammal assemblage has not fared well. The two Rattus species became extinct within two decades of the island's settlement (Andrews 1909; Wyatt et al. 2008; Green 2014). The pipistrelle became extinct in 2009 (Lunney et al. 2011; Martin et al. 2012; Woinarski et al. 2017). The two remaining species (the shrew and flying-fox) are recognised globally and nationally as threatened (Table 1), and, with no records since 1985 , the shrew is probably extinct. 
TABLE 1A Christmas Island endemic plant and animal species that are listed as threatened at national or global level. EPBCA-listed status refers to the Australian listing (as at December 2019) under the Environment Protection and Biodiversity Conservation Act.

\begin{tabular}{|c|c|c|}
\hline Species & National status & Global (IUCN) status \\
\hline \multicolumn{3}{|l|}{ Plants } \\
\hline Lister's palm Arenga listeri & & Endangered \\
\hline \multicolumn{3}{|l|}{ Invertebrates } \\
\hline Christmas Island stick-insect Ramulus stilpnoides & & Vulnerable \\
\hline \multicolumn{3}{|l|}{ Reptiles } \\
\hline Lister's gecko Lepidodactylus listeri & Critically endangered & Extinct (in the wild) \\
\hline Christmas Island giant gecko Cyrtodactylus sadleiri & Endangered & Endangered \\
\hline Blue-tailed skink Cryptoblepharus egeriae & Critically endangered & Extinct (in the wild) \\
\hline Forest skink Emoia nativitatis & Critically endangered & Extinct \\
\hline Christmas Island blind snake Ramphotyphlops exocoeti & Vulnerable & Endangered \\
\hline \multicolumn{3}{|l|}{ Birds } \\
\hline Christmas Island frigatebird Fregata andrewsi & Endangered & Critically endangered \\
\hline Abbott's booby Papasula abbotti & Endangered & Endangered \\
\hline Christmas Island hawk-owl Ninox natalis & Vulnerable & Vulnerable \\
\hline \multicolumn{3}{|l|}{ Mammals } \\
\hline Maclear's rat Rattus macleari & Extinct & Extinct \\
\hline Bulldog rat Rattus navitatis & Extinct & Extinct \\
\hline Christmas Island pipistrelle Pipistrellus murrayi & Critically endangered & Extinct \\
\hline Christmas Island shrew Crocidura trichura & Critically endangered & Critically endangered \\
\hline
\end{tabular}

TABLE 1B Christmas Island endemic plant and animal subspecies that are listed as threatened at national level (note that subspecies are not listed at global level).

* Pteropus natalis is treated here as an endemic species, although under both national and global threatened species listings, it is treated as a subspecies.

\section{Plants}

Tectaria devexa var. minor

Endangered

\section{Birds}

White-tailed tropicbird Phaethon lepturus fulvus

Endangered

Christmas Island emerald dove Chalcophaps indica natalis

Christmas Island goshawk Accipiter (hiogaster) natalis

Christmas Island thrush Turdus poliocephalus erythropleurus

\section{Mammals}

Christmas Island flying-fox Pteropus (melanotus) natalis
Endangered

Endangered

Endangered

Critically endangered* 


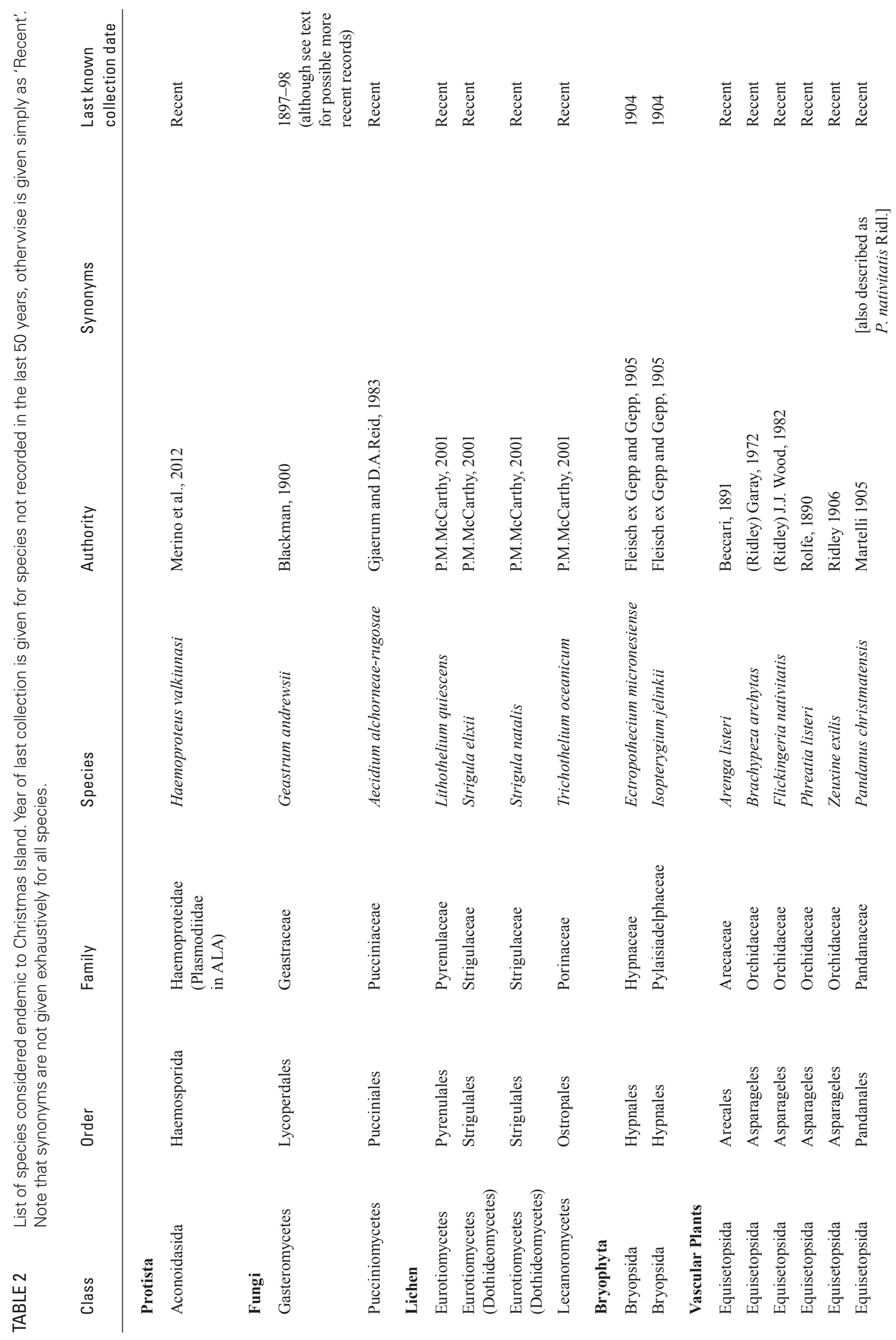




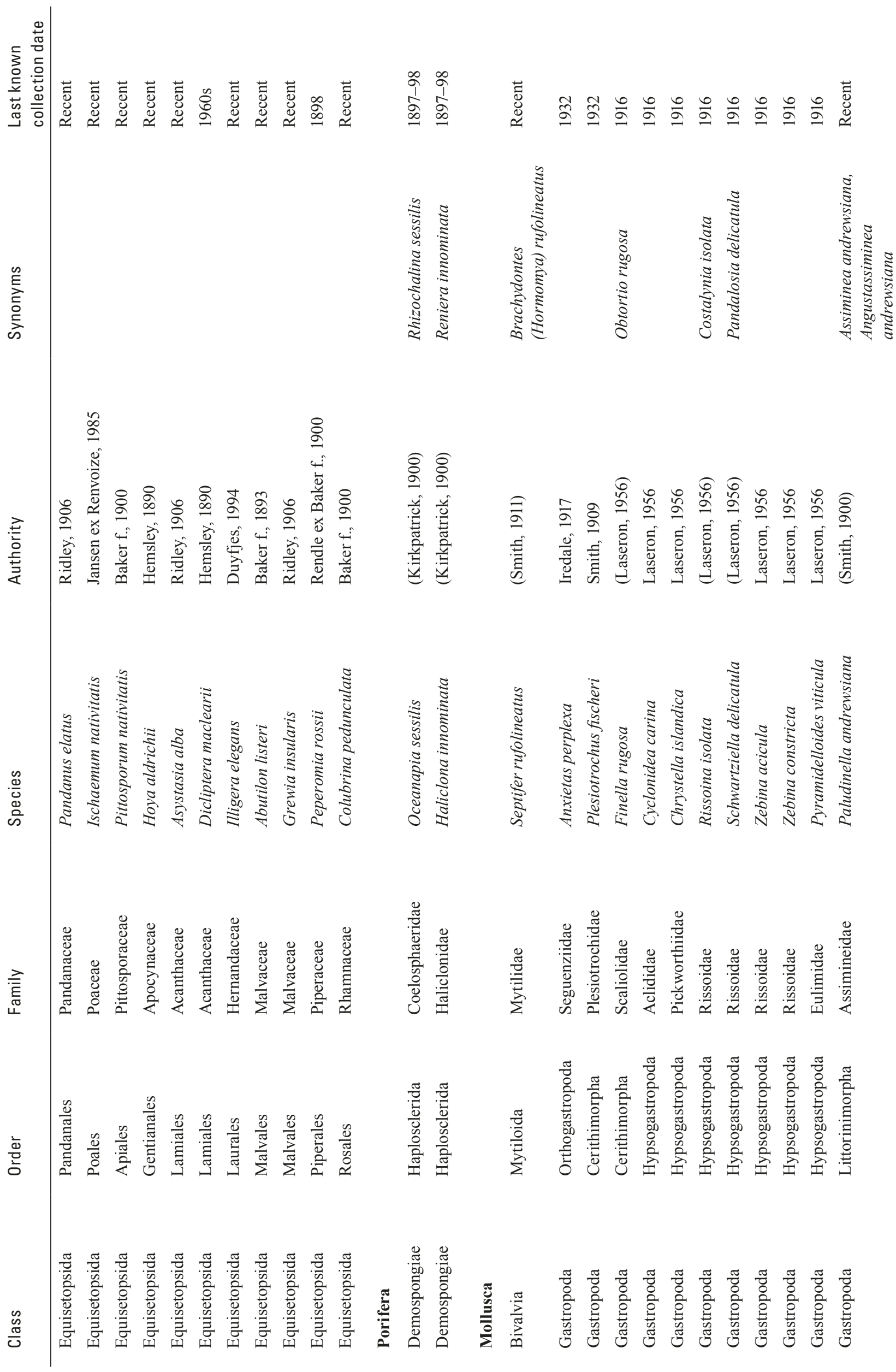




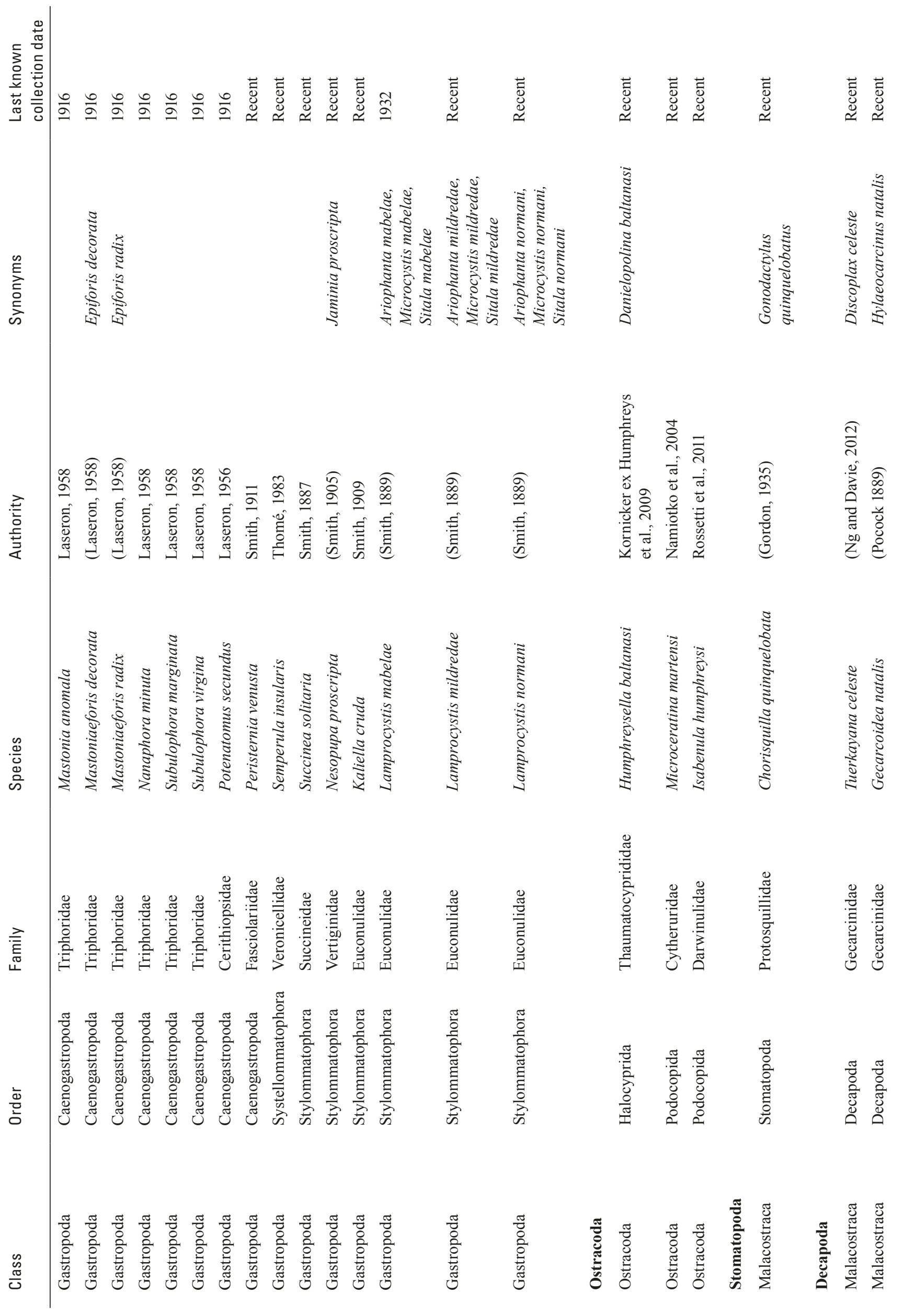




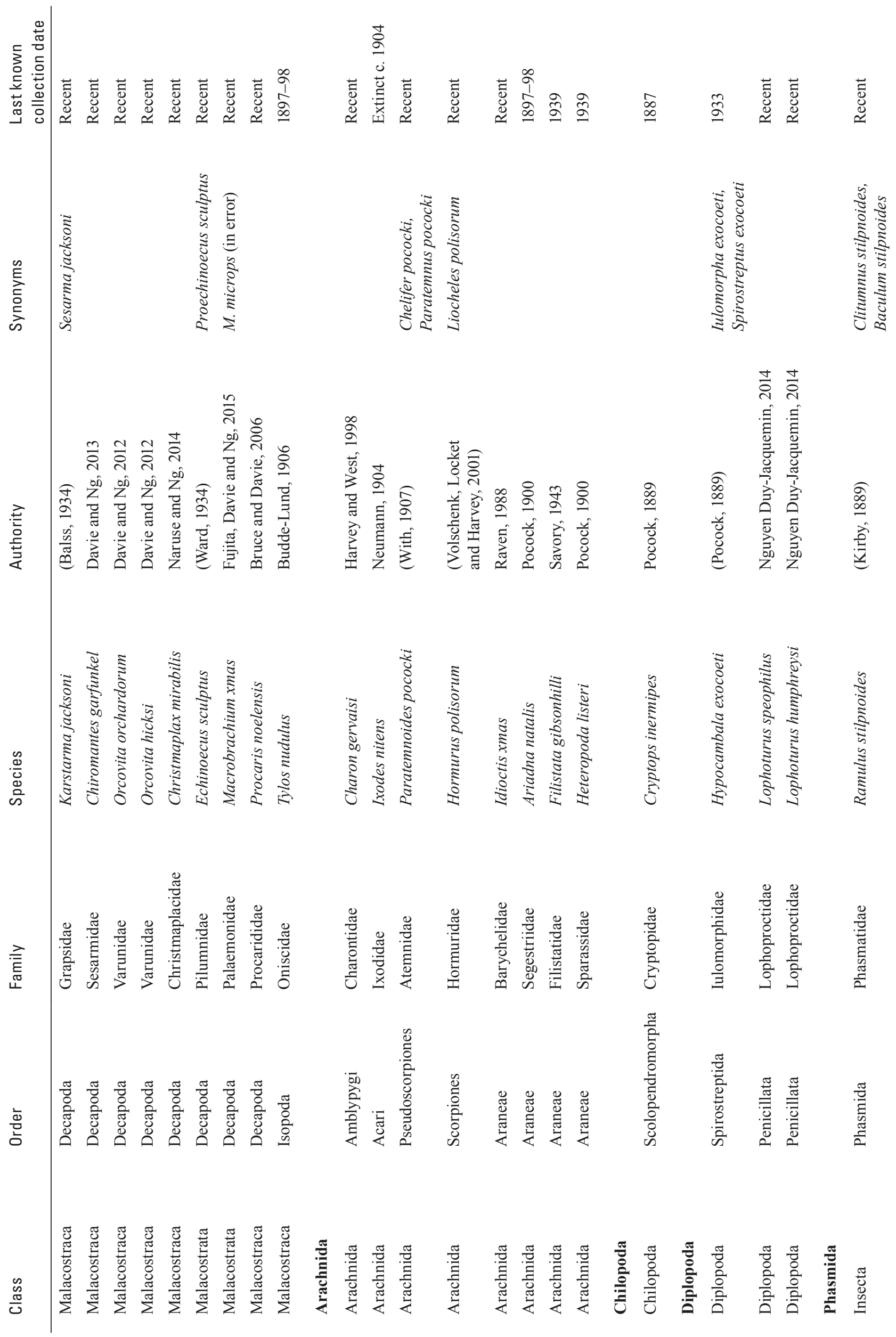




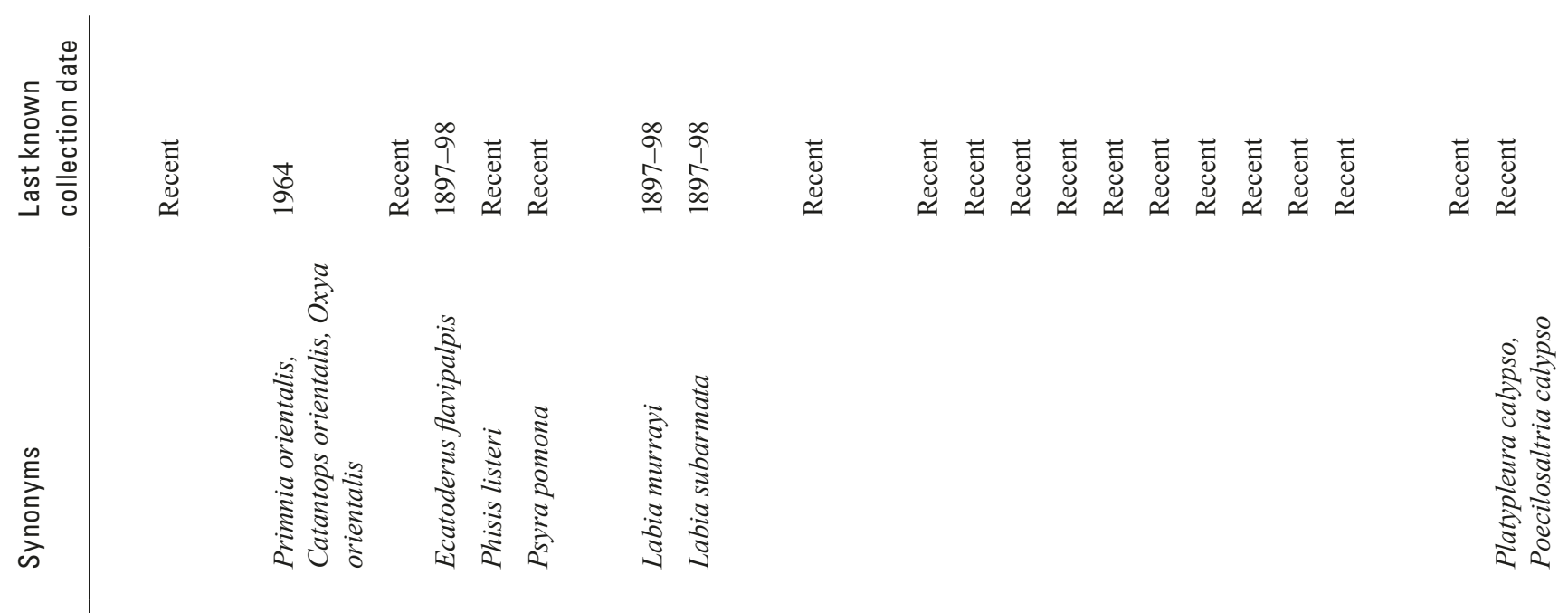

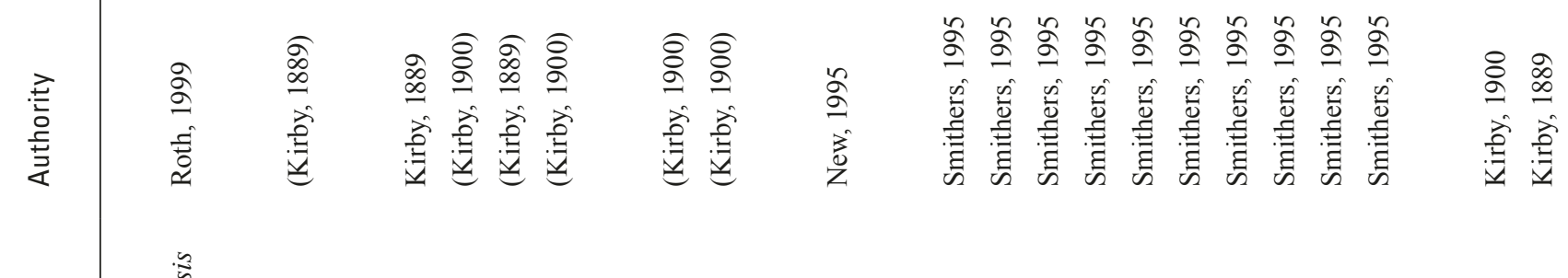

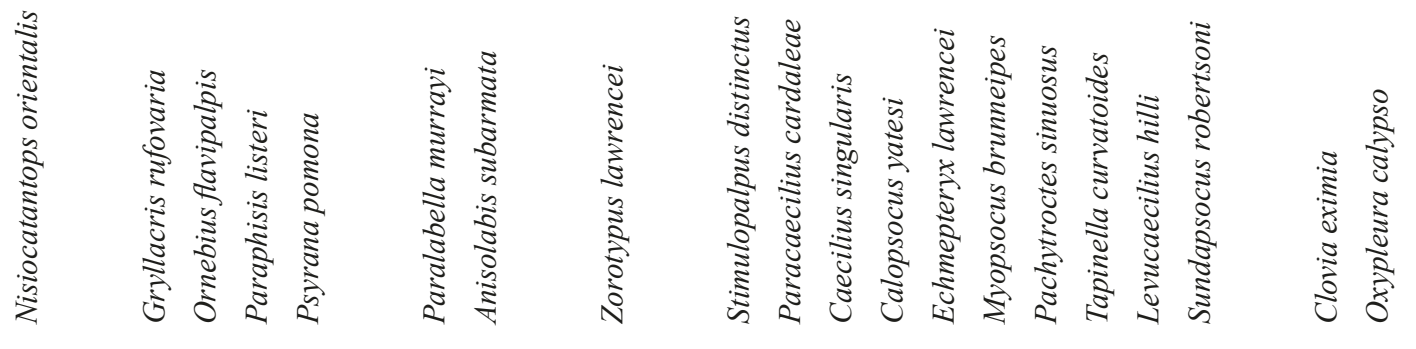

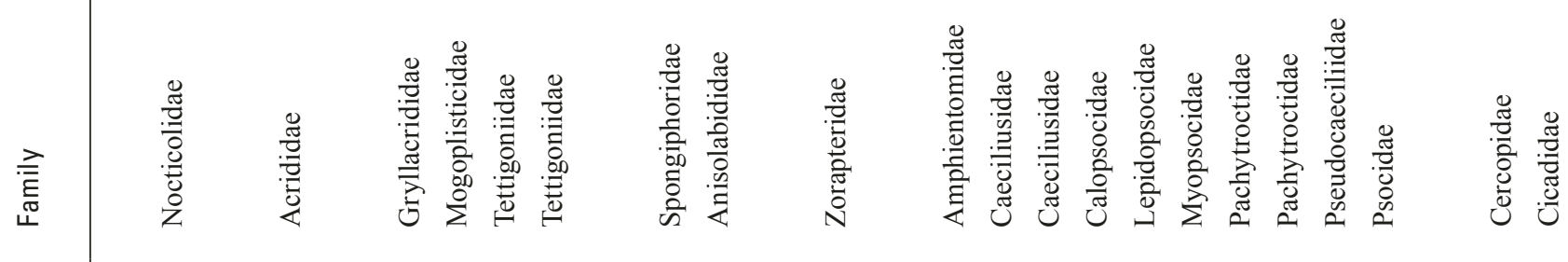

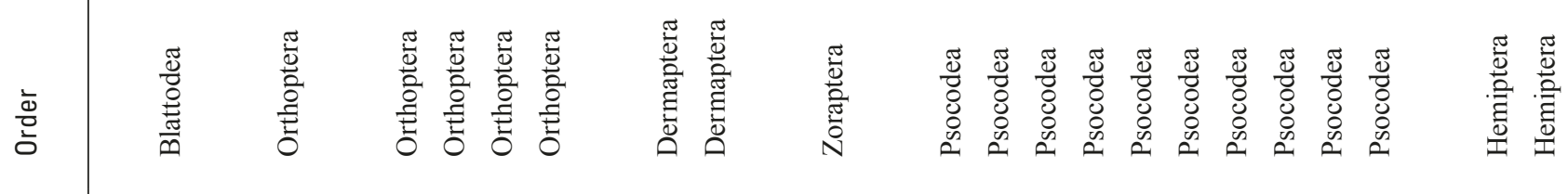

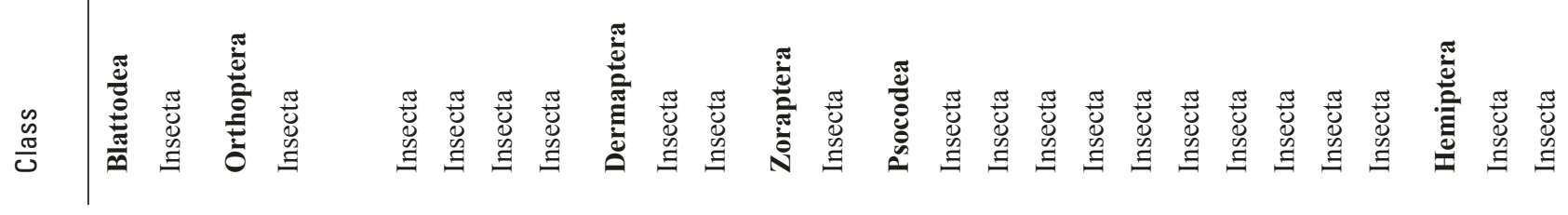




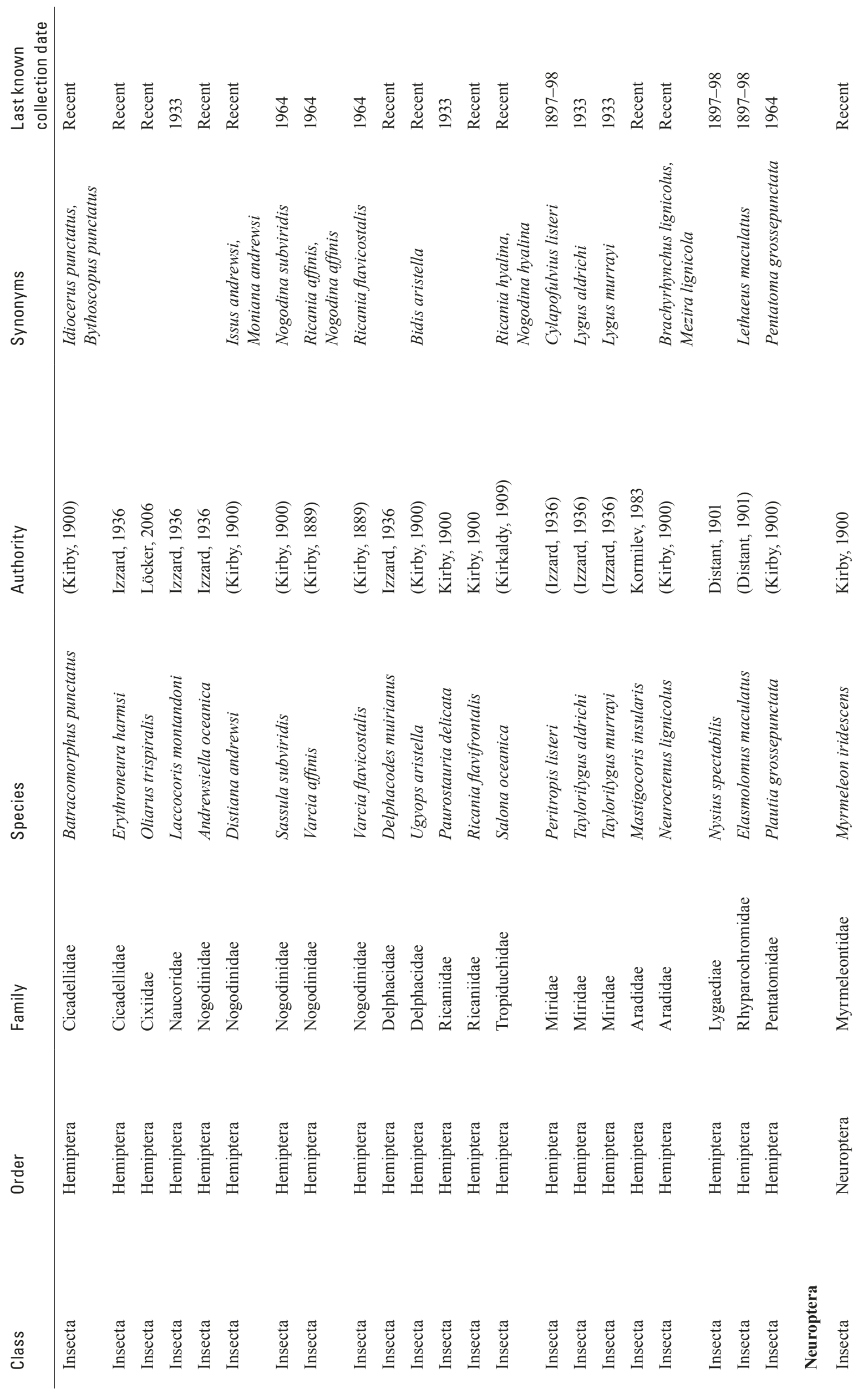




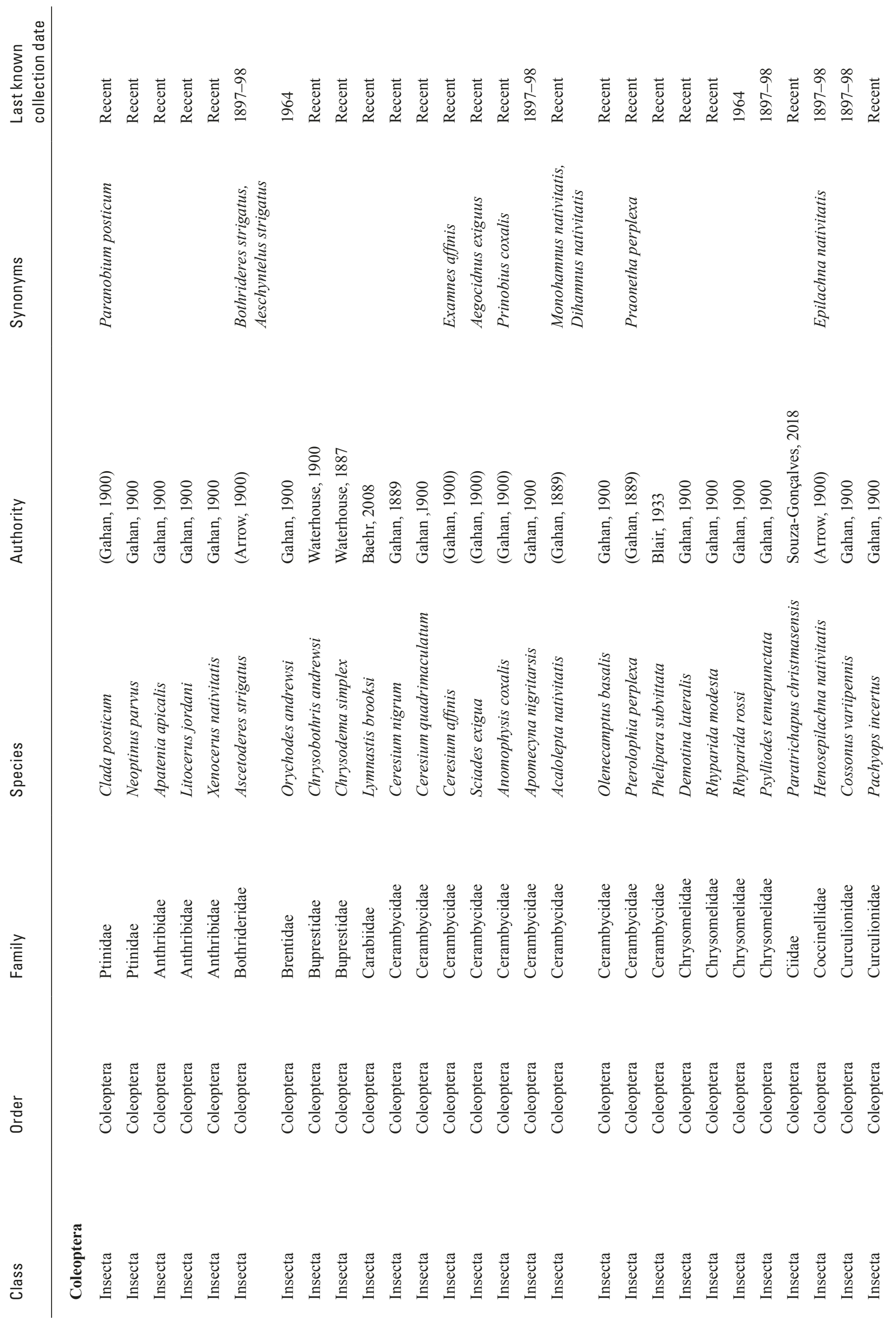




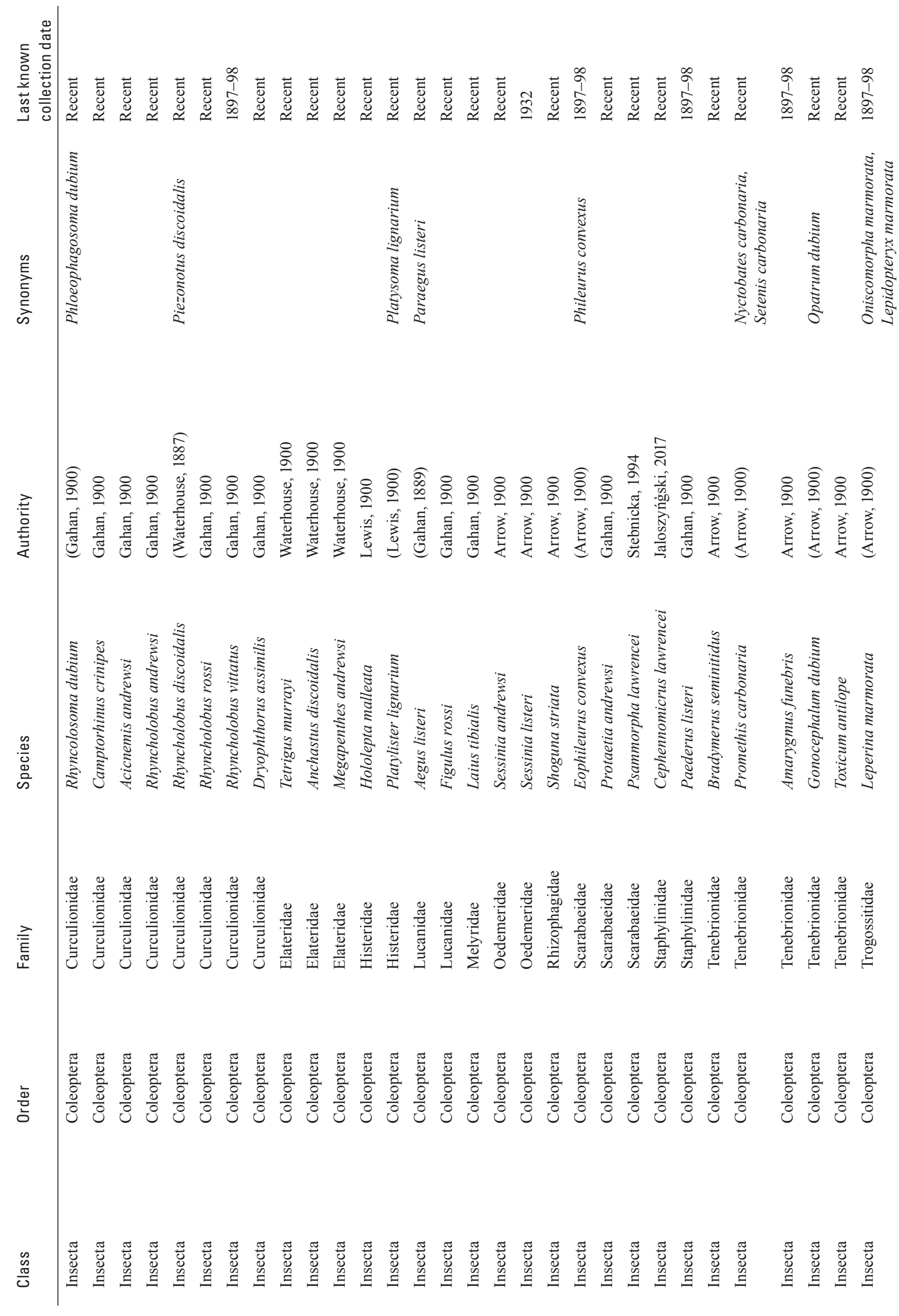




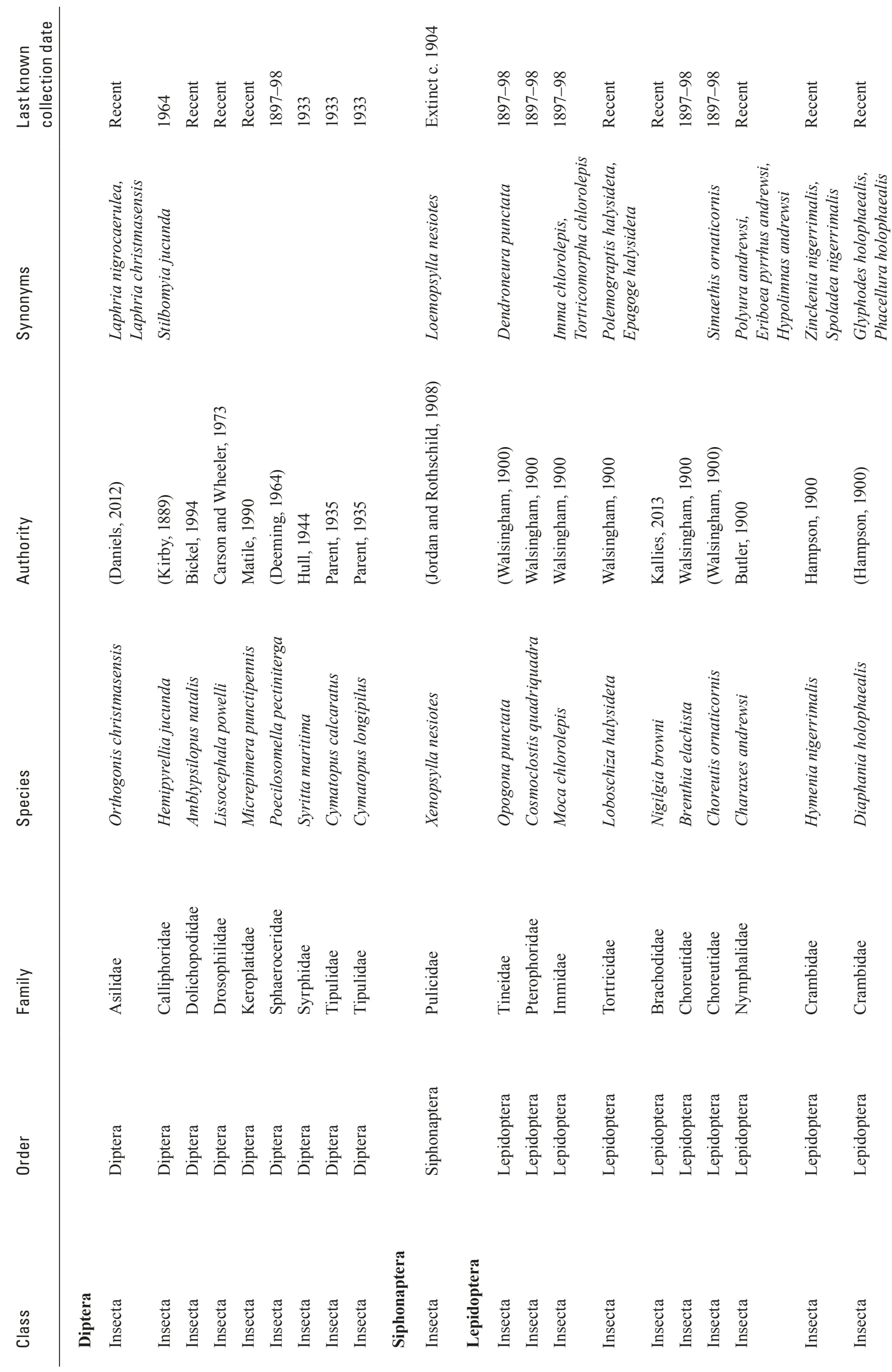




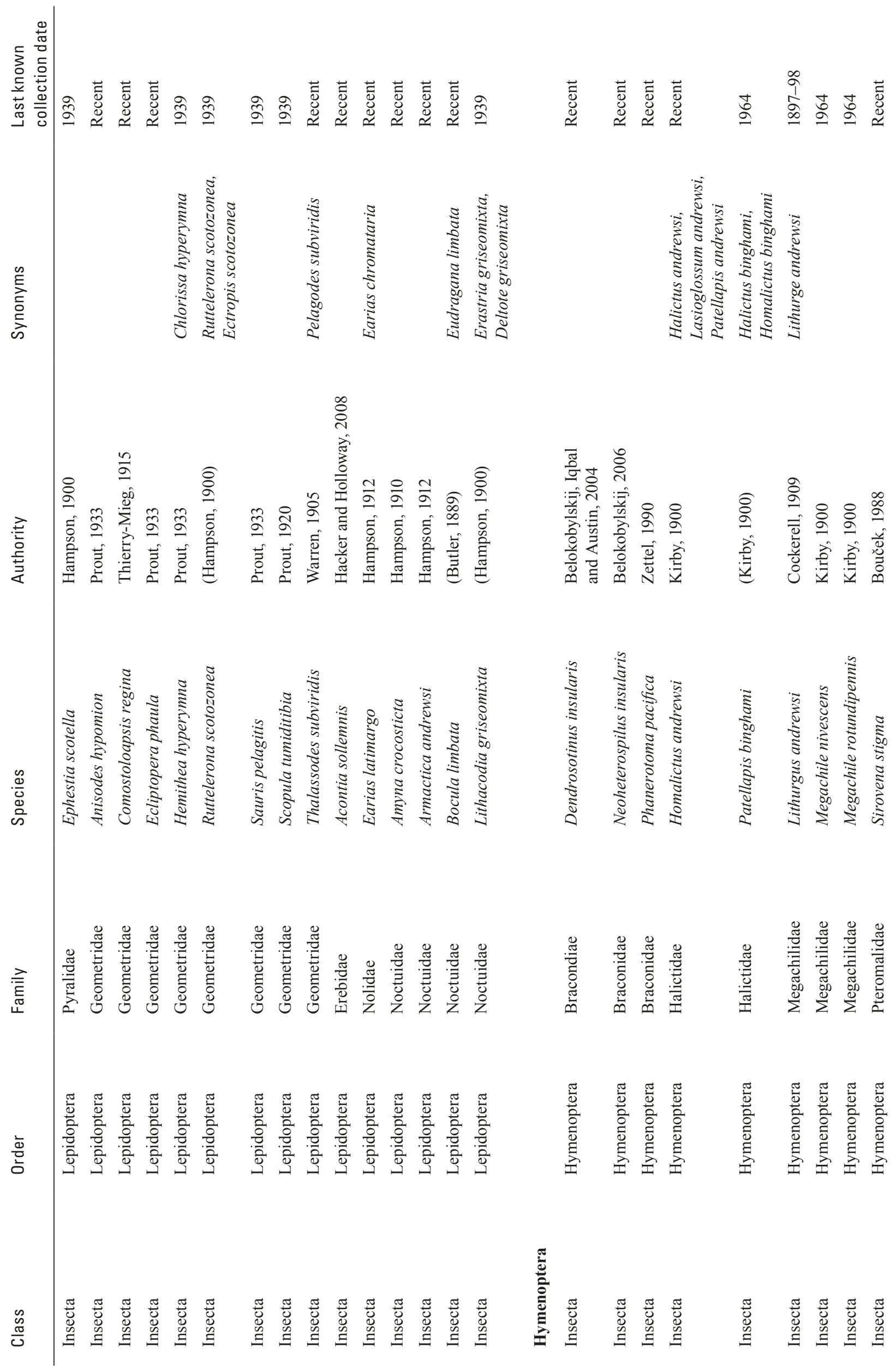




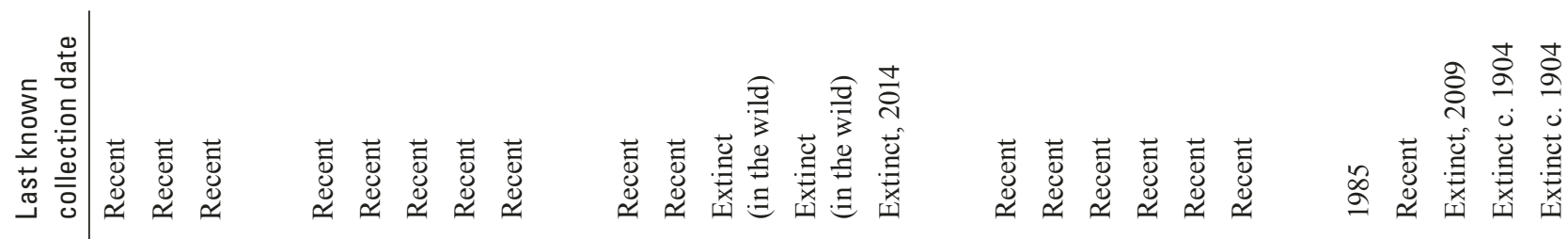

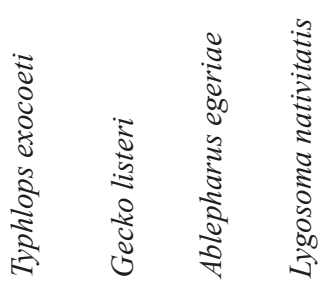

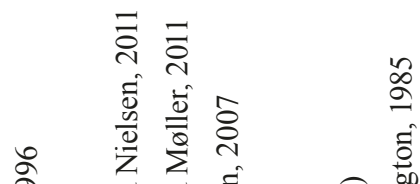

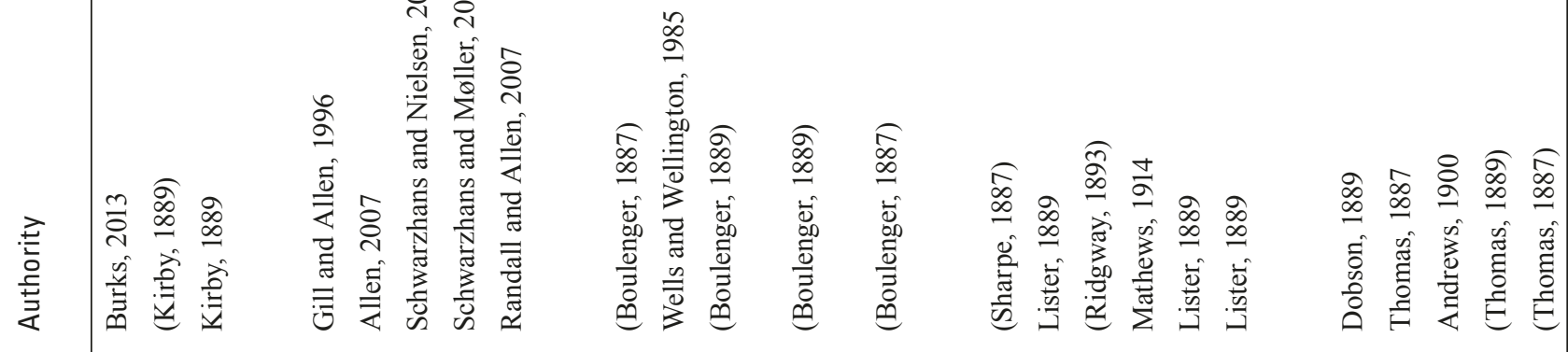

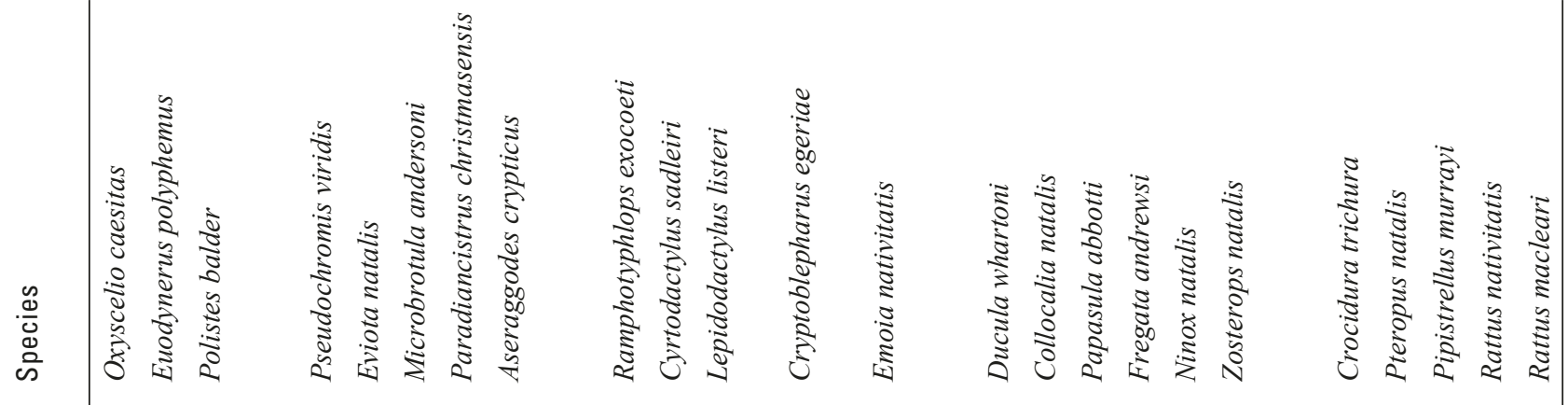

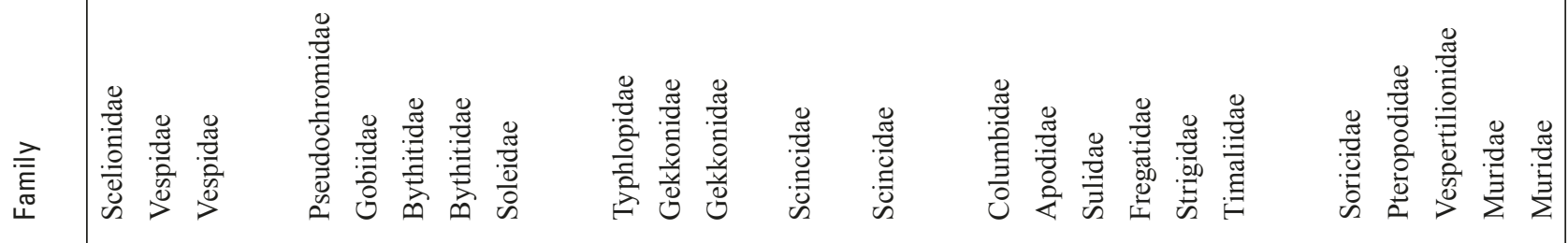

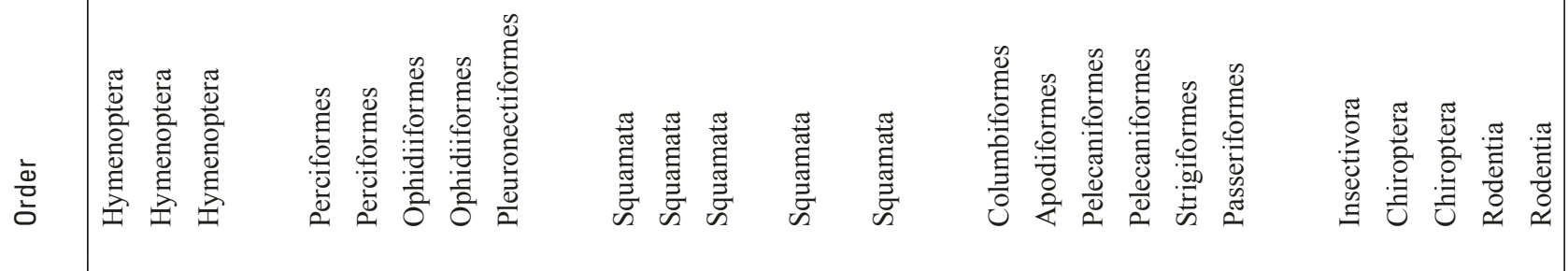

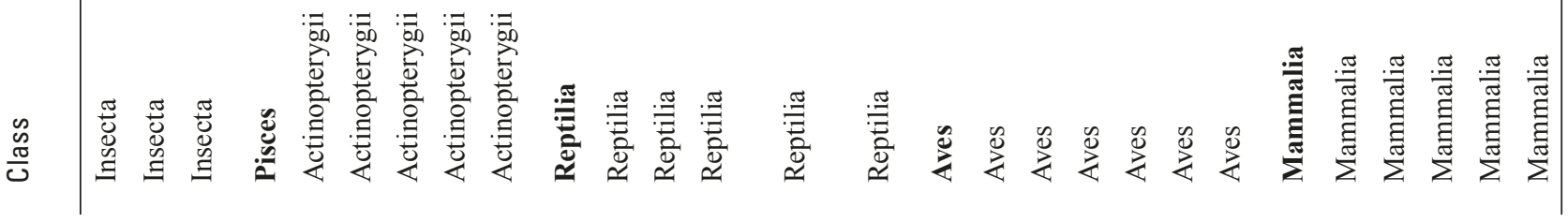


TABLE 3 List of putative undescribed taxa that are potentially new endemic species to Christmas Island.

\begin{tabular}{|c|c|c|c|c|}
\hline Class & Order & Family & Affinities & Source \\
\hline Gastropoda & Hypsogastropoda & Cypraeidae & Lyncina sp. nov. & Meyer (2004) in Tan and Low (2014) \\
\hline Gastropoda & Architaenioglossa & Cyclophoridae & Leptopoma sp. nov. & Tan and Low (2014) \\
\hline Gastropoda & Hypsogastropoda & Assimineidae & gen nov. sp. nov. & Kessner (2006) \\
\hline Gastropoda & Littorinimorpha & Charopidae & Charopa sp.nov. & Laidlaw (1935); Kessner (2006) \\
\hline Polychaeta & Spionida & Spionidae & Prionospio sp. nov. & $\begin{array}{l}\text { Molecular phylogeny by } \\
\text { K. Worsaae (pers. comm.). }\end{array}$ \\
\hline Ostracoda & Podocopida & Darwinulidae & Vestalenula sp. E & Rossetti et al. (2011) \\
\hline Ostracoda & Podocopida & Darwinulidae & Penthesilenula sp. nov. & Humphreys (2014) \\
\hline Maxillopoda & Calanoida & Arietellidae & gen. nov., sp. nov. & Bruce and Davie (2006) \\
\hline Malacostraca & Isopoda & Armadillidae & Myrmecodillo sp. nov. 1 & Humphreys and Eberhard (2001) \\
\hline Malacostraca & Isopoda & Armadillidae & Myrmecodillo sp. nov. 2 & Humphreys and Eberhard (2001) \\
\hline Malacostraca & Isopoda & Armadillidae & Myrmecodillo sp. nov. 3 & Humphreys (2014) \\
\hline Malacostraca & Isopoda & Armadillidae & Myrmecodillo sp. nov. 4 & Humphreys (2014) \\
\hline Malacostraca & Isopoda & Eubelidae & Elumoides sp.nov. & Humphreys (2014) \\
\hline Malacostraca & Isopoda & Philosciidae & Papuaphiloscia sp. nov. 1 & Humphreys and Eberhard (2001) \\
\hline Malacostraca & Isopoda & Philosciidae & Papuaphiloscia sp. nov. 2 & Humphreys (2014) \\
\hline Malacostraca & Thermosbaenacea & Halosbaenidae & Halosbaena sp. nov. & Humphreys (2014) \\
\hline Malacostraca & Decapoda & Paguridae & gen. nov., sp. nov. 1 & Tan et al. (2014b) \\
\hline Malacostraca & Decapoda & Paguridae & gen. nov., sp. nov. 2 & Tan et al. (2014b) \\
\hline Malacostraca & Decapoda & Diogenidae & Clibanarius sp. nov. & Tan et al. (2014b) \\
\hline Arachnida & Pseudoscorpiones & Chthoniidae & Tyrannochthonius sp. nov. 1 & Humphreys (2014) \\
\hline Arachnida & Pseudoscorpiones & Chthoniidae & Tyrannochthonius sp. nov. 2 & Humphreys (2014) \\
\hline Arachnida & Schizomida & Hubbardiidae & Apozomus sp. nov. & Humphreys (2014) \\
\hline Entognatha & Diplura & Campodeidae & Cocytocampa sp. nov. 2 & Humphreys and Eberhard (2001) \\
\hline Insecta & Zygentoma & Nicoletiidae & Metrinura sp. nov. & Humphreys and Eberhard (2001) \\
\hline Insecta & Blattodea & Blattellidae & gen. nov., sp. nov. & Humphreys and Eberhard (2001) \\
\hline Insecta & Orthoptera & Mogoplistidae & Mogoplistinae gen? sp. nov. & CSIRO Division of Entomology (1990) \\
\hline Insecta & Orthoptera & Tettigoniidae & gen?, sp. nov. & Humphreys and Eberhard (2001) \\
\hline Insecta & Hemiptera & Omaniidae & gen. nov., sp. nov. & CSIRO Division of Entomology (1990) \\
\hline Insecta & Neuroptera & Chrysopidae & Mallada sp. nov.? & New (1991) \\
\hline Insecta & Hymenoptera & Crabronidae & Liris sp. nov. & CSIRO Division of Entomology (1990) \\
\hline Insecta & Hymenoptera & Crabronidae & Tachysphex sp. nov. & CSIRO Division of Entomology (1990) \\
\hline Insecta & Hymenoptera & Crabronidae & Pison sp. nov. 1 & CSIRO Division of Entomology (1990) \\
\hline Insecta & Hymenoptera & Crabronidae & Pison sp. nov. 2 & CSIRO Division of Entomology (1990) \\
\hline Insecta & Hymenoptera & Vespidae & Subancistrocerus sp. nov. & CSIRO Division of Entomology (1990) \\
\hline
\end{tabular}




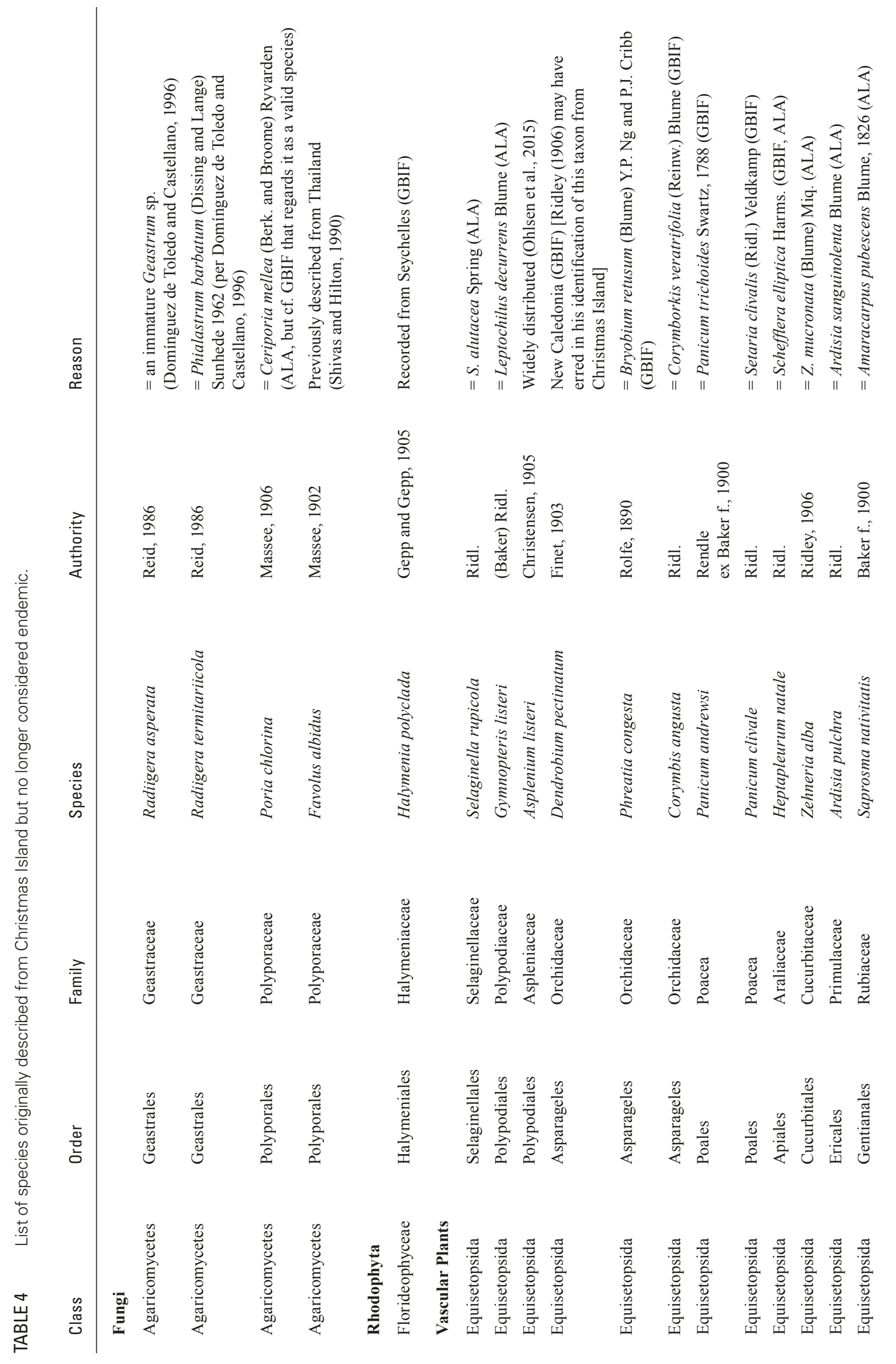




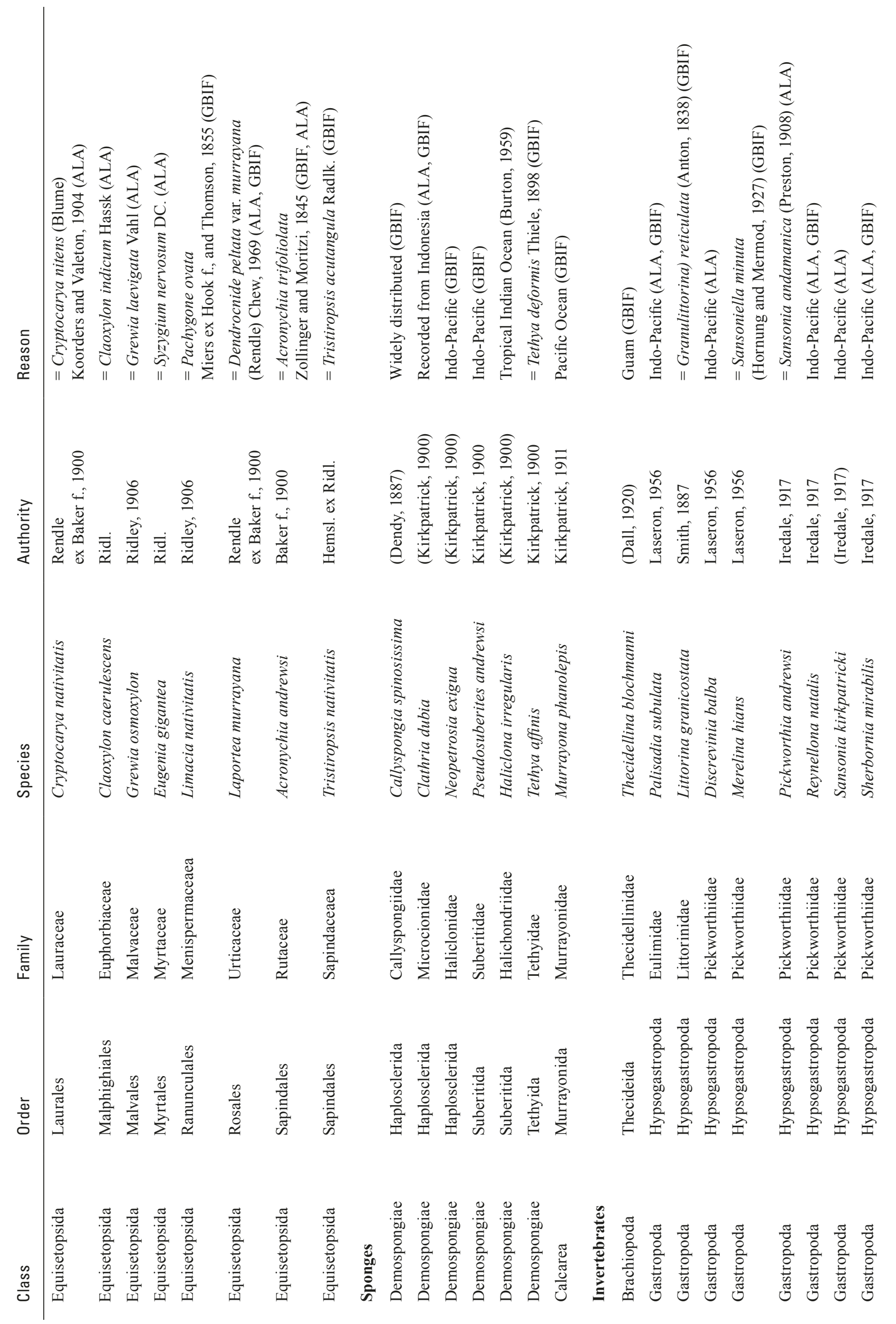




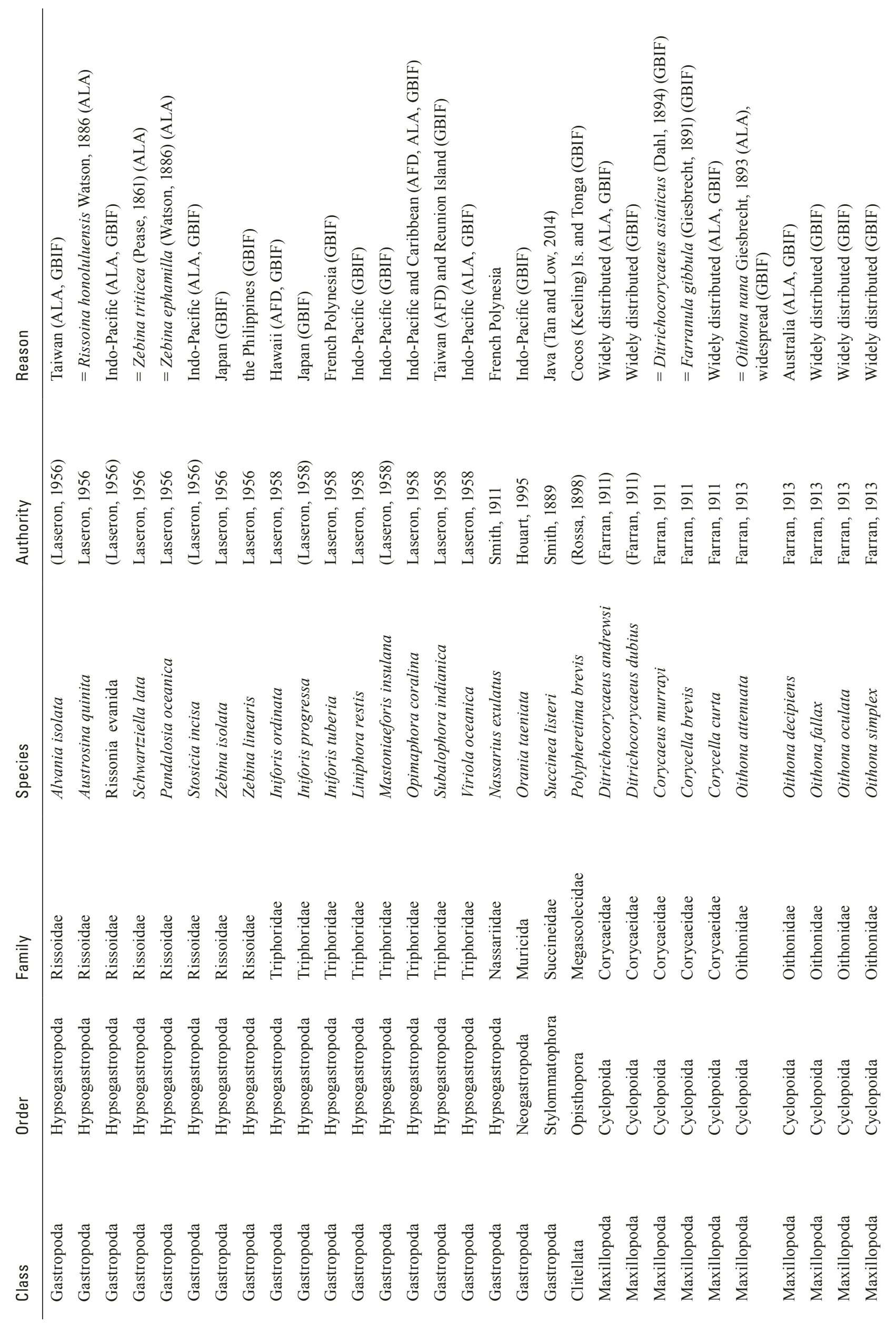




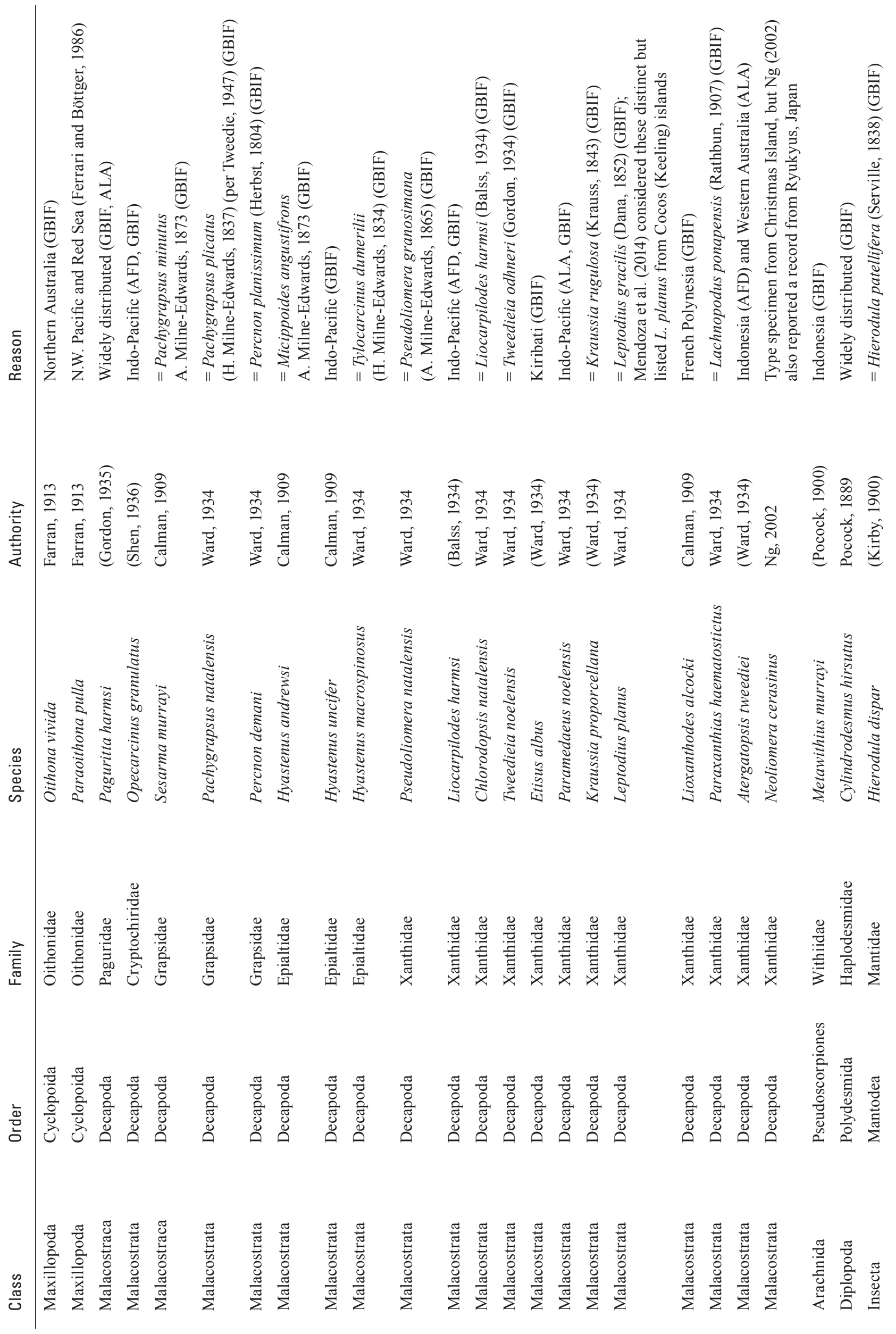




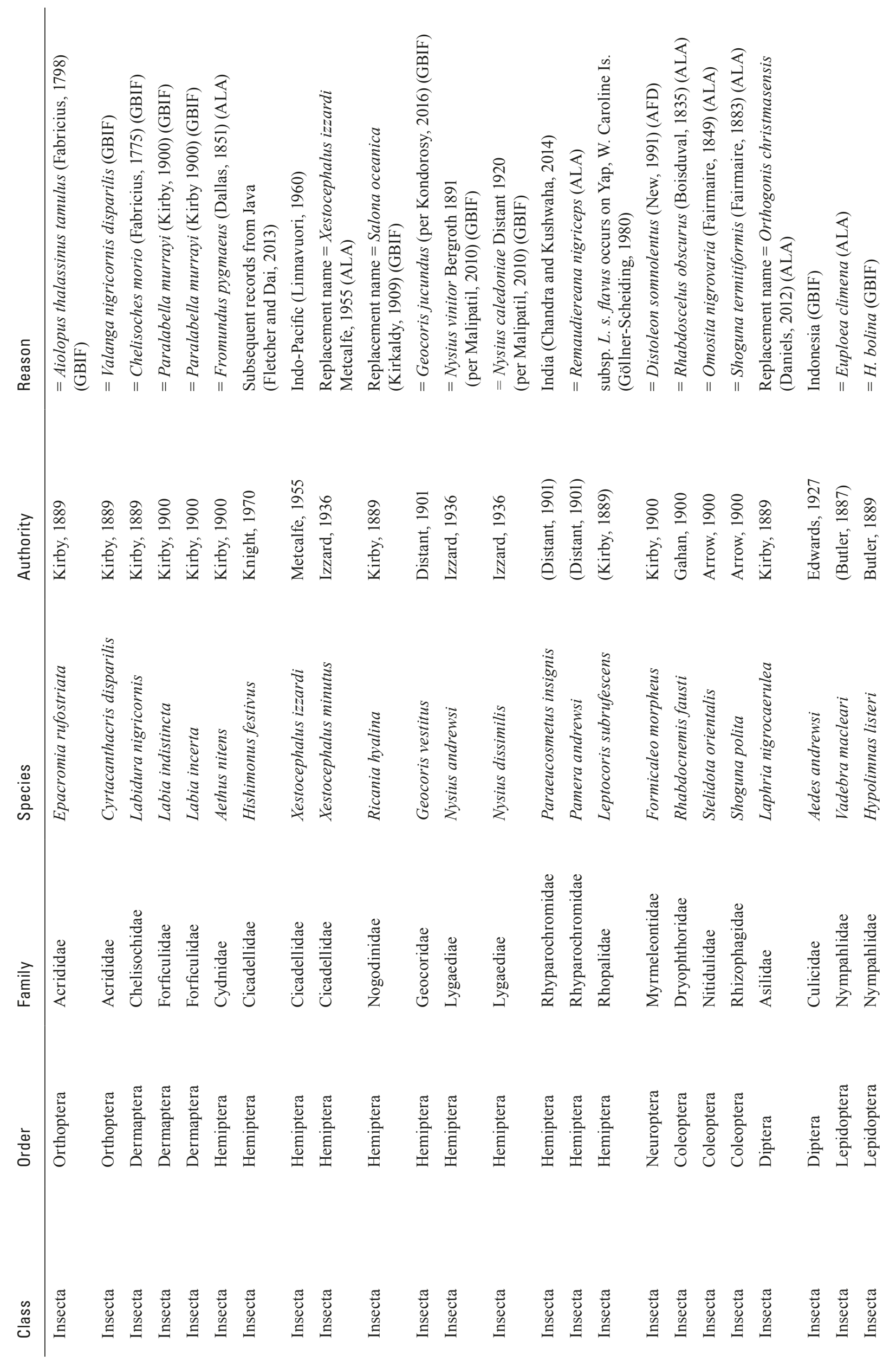




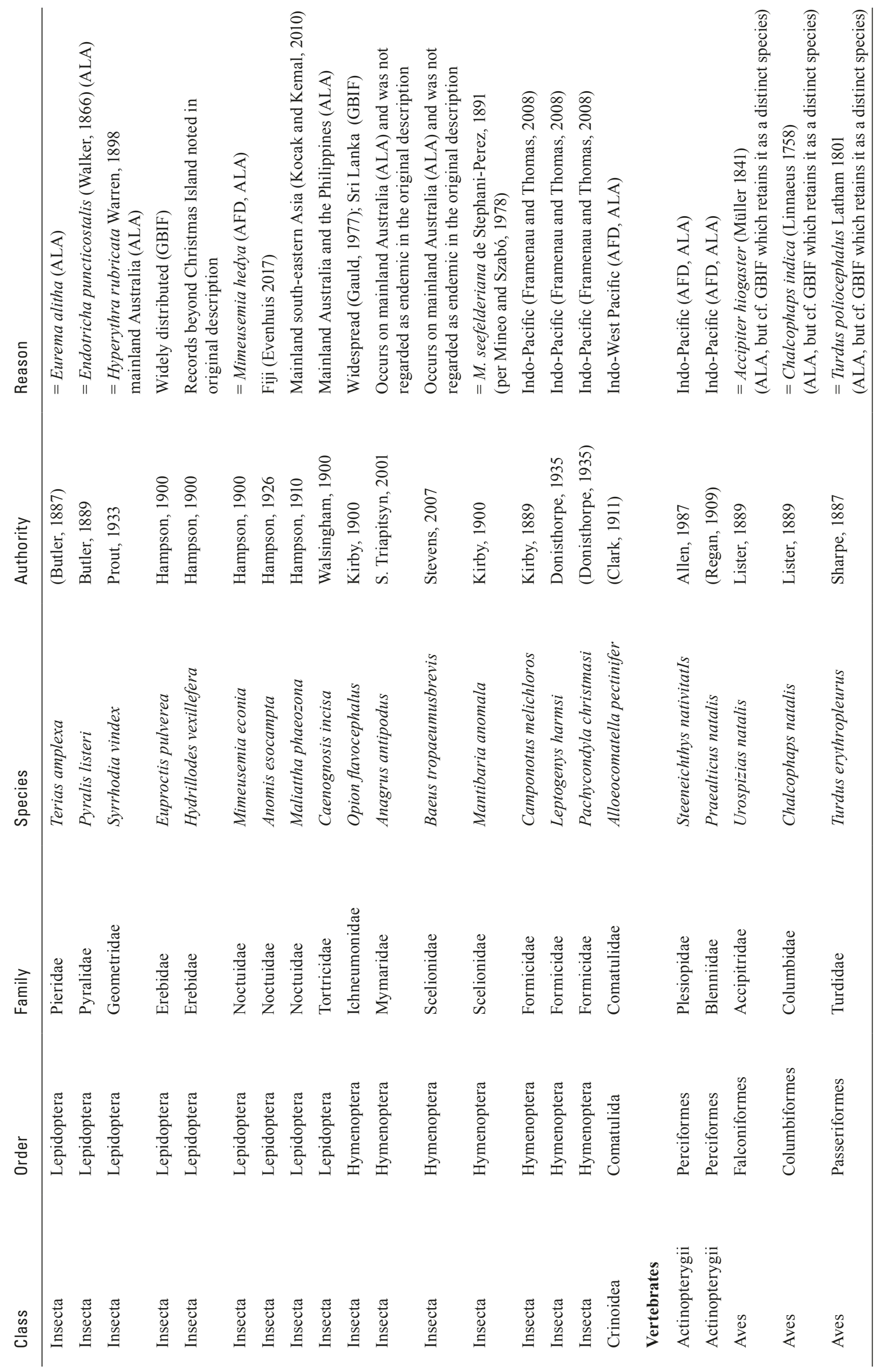




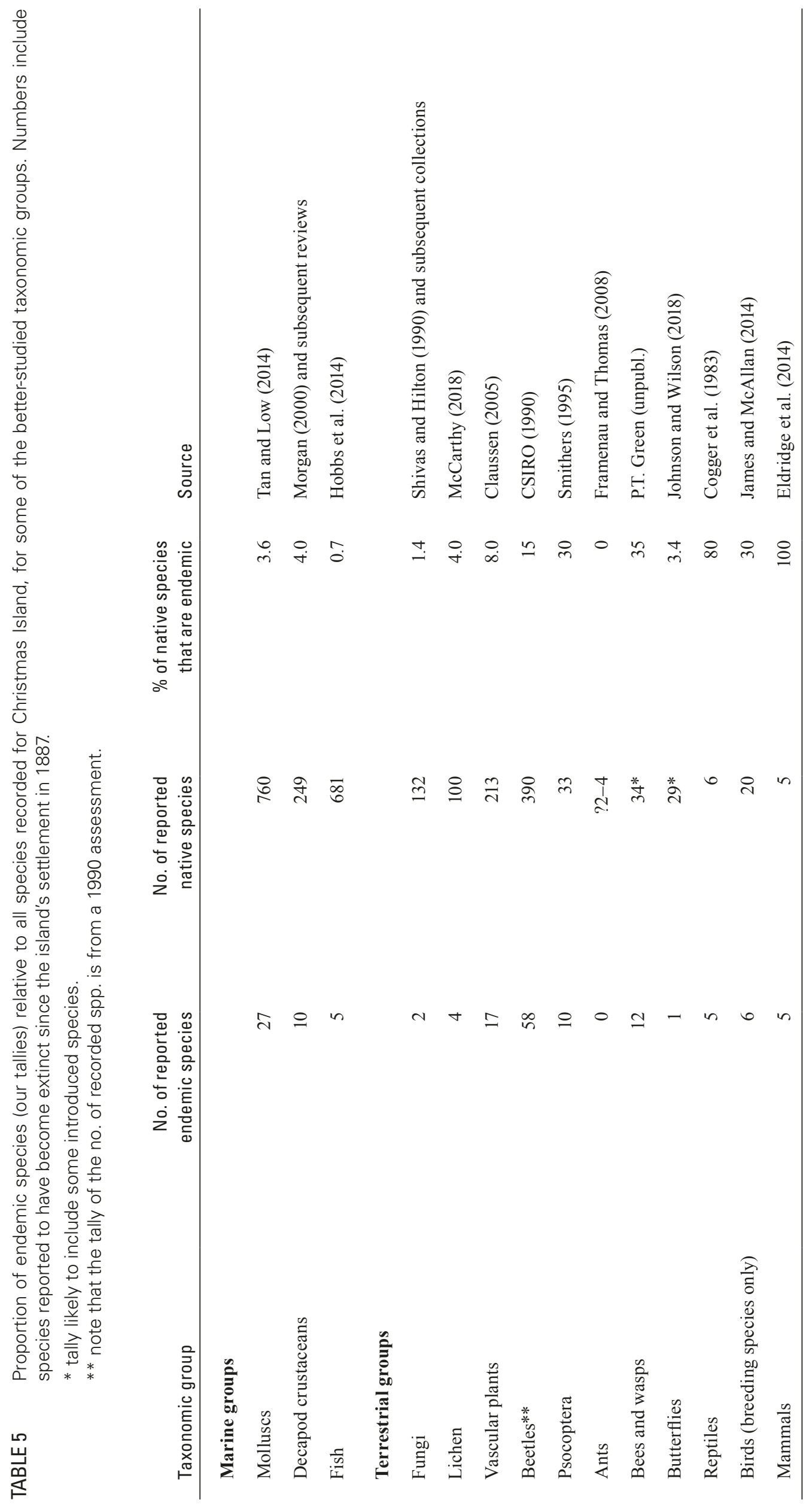


TABLE 6 Date of last known record for Christmas Island species unreported for 50 years or more.

\begin{tabular}{|c|c|c|}
\hline Decade & No. of spp. & Species \\
\hline $1880 \mathrm{~s}$ & 1 & Cryptops inermipes \\
\hline $1890 \mathrm{~s}$ & 29 & $\begin{array}{l}\text { Geastrum andrewsii, Peperomia rossii, Oceanapia sessilis, Haliclona innominata, } \\
\text { Tylos nudulus, Ariadna natalis, Ecatoderus flavipalpis, Paralabella murrayi, Anisolabis } \\
\text { subarmata, Peritropis listeri, Nysius spectabilis, Elasmolomus maculatus, Ascetoderes } \\
\text { strigatus, Apomecyna nigritarsis,-Psylliodes tenuepunctata, Henosepilachna nativitatis, } \\
\text { Cossonus variipennis, Rhyncholobus vittatus, Eophileurus convexus, Paederus listeri, } \\
\text { Amarygmus funebris, Leperina marmorata, Poecilosomella pectiniterga, Opogona } \\
\text { punctata, Moca chlorolepis, Cosmoclostis quadriquadra, Brenthia elachista, Choreutis } \\
\text { ornaticornis, Lithurgus andrewsi }\end{array}$ \\
\hline $1900 \mathrm{~s}$ & 6 & $\begin{array}{l}\text { Ectropothecium micronesiense, Isopterygium jelinkii, Ixodes nitens, Xenopsylla nesiotes, } \\
\text { Rattus nativitatis, Rattus macleari }\end{array}$ \\
\hline $1910 \mathrm{~s}$ & 15 & $\begin{array}{l}\text { Finella rugosa, Cyclonidea carina, Chrystella islandica, Rissoina isolata, Schwartziella } \\
\text { delicatula, Zebina acicula, Zebina constricta, Pyramidelloides viticula, Mastonia } \\
\text { anomala, Mastoniaeforis decorata, Mastoniaeforis radix, Nanaphora minuta, Subulophora } \\
\text { marginata, Subulophora virgina, Potenatomus secundus }\end{array}$ \\
\hline 1920 s & 0 & \\
\hline $1930 \mathrm{~s}$ & 20 & $\begin{array}{l}\text { Anxietas perplexa, Plesiotrochus fischeri, Lamprocystis mabelae, Filistata gibsonhilli, } \\
\text { Heteropoda listeri, Hypocambala exocoeti, Laccocoris montandoni, Paurostauria delicata, } \\
\text { Taylorilygus aldrichi, Taylorilygus murrayi, Sessinia listeri, Syritta maritima, Cymatopus } \\
\text { calcaratus, Cymatopus longipilus, Ephestia scotella, Hemithea hyperymna, Ruttelerona } \\
\text { scotozonea, Sauris pelagitis, Scopula tumiditibia, Lithacodia griseomixta }\end{array}$ \\
\hline $1940 \mathrm{~s}$ & 0 & \\
\hline $1950 \mathrm{~s}$ & 0 & \\
\hline $1960 \mathrm{~s}$ & 12 & $\begin{array}{l}\text { Dicliptera maclearii, Nisiocatantops orientalis, Sassula subviridis, Varcia affinis, Varcia } \\
\text { flavicostalis, Plautia grossepunctata, Orychodes andrewsi, Rhyparida rossi, Hemipyrellia } \\
\text { jucunda, Patellapis binghami, Megachile nivescens, Megachile rotundipennis }\end{array}$ \\
\hline
\end{tabular}

TABLE 7 Comparison of numbers of endemic terrestrial species, and their fate, among some of Australia's oceanic islands. Extinctions here include species that are formally and validly listed as extinct or extinct in the wild by the IUCN, Australian or relevant state/territory jurisdictions, with these tallies undoubtedly underestimating the actual number of extinctions. See text for main information sources for Lord Howe and Norfolk Island groups.

* One additional now extinct species (Aplonis fusca) occurred only on both Lord Howe and Norfolk Islands.

\begin{tabular}{|c|c|c|c|}
\hline & Christmas & Lord Howe & Norfolk \\
\hline Island area $\left(\mathrm{km}^{2}\right)$ & 137 & 16 & 36 \\
\hline Island area including satellite islands $\left(\mathrm{km}^{2}\right)$ & 137 & 17 & 38 \\
\hline No. of endemic plant spp. & 17 & c. 100 & c. 38 \\
\hline No. of endemic plant genera & 0 & 5 & 2 \\
\hline No. of extinct endemic plant spp. & 0 & 1 & 1 \\
\hline No. of endemic invertebrate spp. & c. 200 & c. 600 & no known estimate \\
\hline No. of endemic invertebrate genera & 9 & c. 40 & no known estimate \\
\hline No. of extinct endemic invertebrate spp. & 0 & 1 & 1 \\
\hline No. of endemic terrestrial vertebrate spp. & 16 & 5 & 4 \\
\hline No. of extinct endemic vertebrate spp. & 6 & $4^{*}$ & $2 *$ \\
\hline
\end{tabular}




\section{DISCUSSION}

There are distinctive features of the biodiversity sampling history of Christmas Island that render this exercise both easy and difficult. The unusually extensive taxonomic breadth and sampling intensity of the early (1887-1908) collections at the onset of the island's settlement provide, for many taxonomic groups, an almost unparalleled baseline inventory. Those collections help to now determine which species in the current biota are native and which have subsequently been introduced, and which species may have subsequently been rendered extinct. However, for many taxonomic groups, those early collections have not been repeated, and without recent sampling it is now difficult to assess whether some of the long-ago described species (often represented in collections by the holotype only or a very few specimens) are still valid, and the extent to which those species have persisted, declined or become extinct.

The ascription of endemism proved challenging for many taxa, because: (i) for many species there were few records (rendering it difficult to describe the bounds of their distribution); (ii) for some species described long ago it was difficult to trace the subsequent taxonomic treatment; (iii) there is inconsistency in current specific recognition; and (iv) some taxa considered as endemic in previous studies are yet to be described.

We conclude that at least 253 described species are endemic to Christmas Island (Table 2). Most are insects (150 species), with the highest numbers in the orders Coleoptera (58 species), Lepidoptera (25 species), Hemiptera (24 species), Hymenoptera (12 species), and Psocodea (10 species); there are also 27 endemic species of Mollusca, 17 vascular plants, 15 crustaceans, eight arachnids, six birds, five fish, five reptiles and five mammals. A further 34 species were considered to be endemic, or probably so, by those documenting their occurrence, but have not yet been formally described (Table 3). Our tallies for, and the complement of, endemic species represent a notable advance on that presented in a recent listing of endemic species from several Australian islands, including Christmas Island (Morris et al. 2018). That listing considered that there were 36 species and five subspecies endemic to Christmas Island (18 plants, four invertebrates, four reptiles, ten birds and five mammals). Four of these are shown here not to be endemic species (Dendrocnide peltata, Zehneria alba, Asplenium listeri and Papilio memnon). The disparity between the Morris et al. (2018) list and our assessment is especially pronounced for invertebrates.

Endemism is not restricted to the species level; there are about ten endemic genera - the crab genus Christmaplax, the beetle genera Rhyncholobus and Psammorpha, the hemipteran genera Andrewsiella and Paurostauria (although the validity of the latter genus may merit further scrutiny: Fletcher (2008)), the psocid Sundapsocus, the grasshopper Nisiocatantops, the cockroach Metanocticola, a new genus of copepod (Arietellidae) (Bruce and Davie 2006) and Papasula (comprising Abbott's booby only). The crab family Christmaplacidae, originally based on one Christmas Island species, was considered endemic (Naruse and $\mathrm{Ng}$ 2014) until the recent discovery of another species assigned to the family, from Guam (Mendoza and $\mathrm{Ng}$ 2017).

For those taxonomic groups for which reasonably comprehensive inventories are available, the extent of endemism is summarised in Table 5. For at least reptiles and mammals, a majority of native species present (or formerly present) are endemic. Endemic species comprise a smaller proportion of marine species, presumably due to greater dispersal opportunities in the marine environment. Birds are unusual in that the number of native breeding species is small, but the number of colonising, visiting and vagrant species is proportionally large and growing steadily (James and McAllan 2014). However, we note that this comparison across taxonomic groups in the proportion of endemic species is compromised; for better-studied groups (the vertebrates and vascular plants), the total number of native species and of endemic species is well-documented, whereas neither tally is likely to be complete for poorly-known groups.

Some of the endemic species are of particular evolutionary and biogeographical significance. For example, the ostracods Humphreysella baltanasi and Microceratina martensi, the cave shrimp Procaris noelensis and the cave microshrimp Halosbaena sp. nov. represent lineages of great antiquity and remarkably odd biogeography (Page et al. 2018), and may be relicts of groups originating in the shallows of the Tethys Sea at least as early as the Mesozoic (225 to 65 million years ago) (Namiotko et al. 2004; Humphreys et al. 2009). The relictual endemic Abbott's booby is the most ancestral of all the Sulidae, having diverged from all other living relatives more than 20 million years ago, and to have existed as a species for at least fifteen million years (Olson and Warheit 1988; Patterson et al. 2011). This species, and the Christmas Island frigatebird, both feature in the top 50 bird species globally for their combination of evolutionary distinctness and rarity (Jetz et al. 2014). At least some of the Christmas Island reptile species are also of great antiquity, reflecting a very long period of isolation. For example, recent genetic analyses have demonstrated that the endemic blue-tailed skink, Lister's gecko and forest skink diverged from their nearest living relatives between 5 and 25 million years ago (Oliver et al. 2018).

The number of endemic species listed here is likely to be a substantial under-estimate of the actual number of endemic species given that some taxonomic groups have been subject to no or only cursory inventory. For example, the total list of wasps and bees known from Christmas Island is 34 identified species, of which 
we recognise 12 as endemic. However, the CSIRO expedition of 1989 collected an estimated 299 morphospecies (CSIRO Division of Entomology 1990); Parks Australia collected 71 morpho-species (James 2007) and the CESAR Consulting Group collected a very large number of parasitoid wasp species (Weeks 2013), almost all un-named. Likewise, the rich Psocoptera fauna of Christmas Island was largely undocumented until the 1990s. Most of the recognised species came from a single collection (in 1989) of 246 specimens, representing 33 identifiable species that included ten newly described ones (Smithers 1995). As another example, recent sampling of freshwater invertebrates concluded that 'numerous macroinvertebrate species are thought to be novel uncharacterised taxa that may be endemic to Christmas Island' (V. Pettigrove pers. comm. in Weeks and McColl 2011).

The history of collections on Christmas Island is unusual - it is marked by the extremely substantial sampling undertaken in the 1-2 decades soon after the island's settlement in the 1880 s, most notably by Charles Andrews, with very intermittent sampling subsequent to that (Figure 2). Other than the spurt of new species described in the period 1887-1919, the rate of description of endemic species has been reasonably continuous and shows no sign of reaching an asymptote (Figure 2). As documented in the accounts above, for many taxonomic groups there has been little collecting, for others substantial collections have not yet been worked through, and for yet others new taxa have been recognised but not yet described (e.g. Table 3). Hence, it is likely that many endemic species remain undiscovered and undescribed. Our review also concluded that at least 141 species for which Christmas Island is the type locality are no longer recognised as valid endemic species (Table 4), mostly because the species has subsequently been found elsewhere, or because of taxonomic re-sorting.

On Christmas Island, losses of some endemic species occurred very rapidly. The endemic Maclear's rat Rattus macleari and bulldog rat $R$. nativitatis were extremely abundant at the onset of the island's settlement, but were rendered extinct within a decade (Andrews 1909; Green 2014). The Christmas Island pipistrelle Pipistrellus murrayi remained abundant and apparently secure up to at least the 1980 s but declined rapidly thereafter, culminating in extinction in 2009 (Martin et al. 2012; Woinarski 2018). Likewise, three of the four endemic lizards, and another native but not endemic lizard, were also abundant in the 1980s, but became extinct or extinct in the wild by 2012 (Smith et al. 2012; Andrew et al. 2018). For some of these vertebrates, the rapidity of loss outstripped the pace of formal recognition as threatened. For example, the Christmas Island forest skink Emoia nativitatis was first listed as a threatened species in 2010 (at global scale) and January 2014 (nationally). This was at about the time or after its extinction in the wild in 2010 and shortly before the 2014 death of the last of three individuals collected in the hope of establishing a captive breeding program (Andrew et al. 2018). The belated listing was notwithstanding substantial evidence over several decades of severe decline (Smith et al. 2012). Likewise, the blue-tailed skink Cryptoblepharus egeriae was not listed as threatened globally until it was recognised as extinct in the wild in 2017, again notwithstanding compelling evidence over several decades of rapid and severe decline (Smith et al. 2012).

Fourteen endemic species and six endemic subspecies are listed as threatened at national or global levels (Table 1), including six that are listed as extinct or extinct in the wild. All of the latter are vertebrates. No endemic plant or invertebrate species are listed as threatened at the national level. This listing may now have belatedly caught up with the imperilled (or extinct) status for most terrestrial vertebrates, but it has notably failed to provide adequate (or indeed, any) consideration of the status of the majority of Christmas Island's endemic species, particularly the c. 200 endemic invertebrate species. Only one of these endemic invertebrates (Ramulus stilpnoides) has been accorded any conservation status notwithstanding the absence of records of many species for more than 100 years, and the likelihood that at least some of the threats that have caused decline in endemic plant and terrestrial vertebrate species (e.g. habitat loss, introduction and proliferation of yellow crazy ants and black rats) are also likely to have affected endemic invertebrate species, perhaps to an even greater extent. Even within some relatively well-known groups, there has been anomalous treatment of conservation status assignation. For example, the endemic plant Peperomia rossii has not been recorded since $1897-98$ but has no assigned conservation status. In contrast, the relatively abundant and still widespread palm Arenga listeri is listed as Endangered at the global level.

Although noting the cautionary tale of the rapid recent decline (from abundant in the late 1980s to extinction c. 20 years later) of the Christmas Island pipistrelle and Christmas Island forest skink, the date of the most recent record may provide some indication of the current status or at least flag a cause for concern for some poorly-known endemic species or species-groups. However, this date is also difficult to determine for many taxa given incomplete documentation and determination of some collections. Our assessment indicates that at least 51 of the 253 endemic species $(20 \%)$ have not been reported for at least 100 years, and another 33 endemic species (13\%) have not been reported for 50-100 years (Table 6). For the two vertebrates (Rattus nativitatis and R. macleari) in this list of long-lost species, extinction is validly recognised, but such status has not been formally recognised for the similarly long-missing invertebrate and plant species, although relevant reviews have concluded so for some species, such as the flea Xenopsylla nesiotes and tick Ixodes nitens - both hosted by the extinct endemic Rattus macleari (Mihalca et al. 2011; Colwell et al. 2012; Kwak 2018). 
Many of the endemic species that have not been reported for at least 50 years may now be extinct, and many others highly imperilled and may be in need of urgent conservation management response, lest they too become extinct. However, long periods without reporting may also represent lack of sampling, identification challenges, or simply inconspicuousness, and may be a weak foundation for assuming imperilment. There are several notable examples of re-discovery of Christmas Island endemic species after long absences. For example, Ridley's ground orchid Zeuxine exilis was rediscovered in 2009 after not being reported for more than 100 years (Green et al. 2010), and has now been observed at numerous sites and often in very large numbers (PG pers. obs.). The Christmas Island shrew Crocidura trichura was extremely abundant at the time of the island's settlement (Andrews 1900c), but virtually disappeared between 1900 and

A

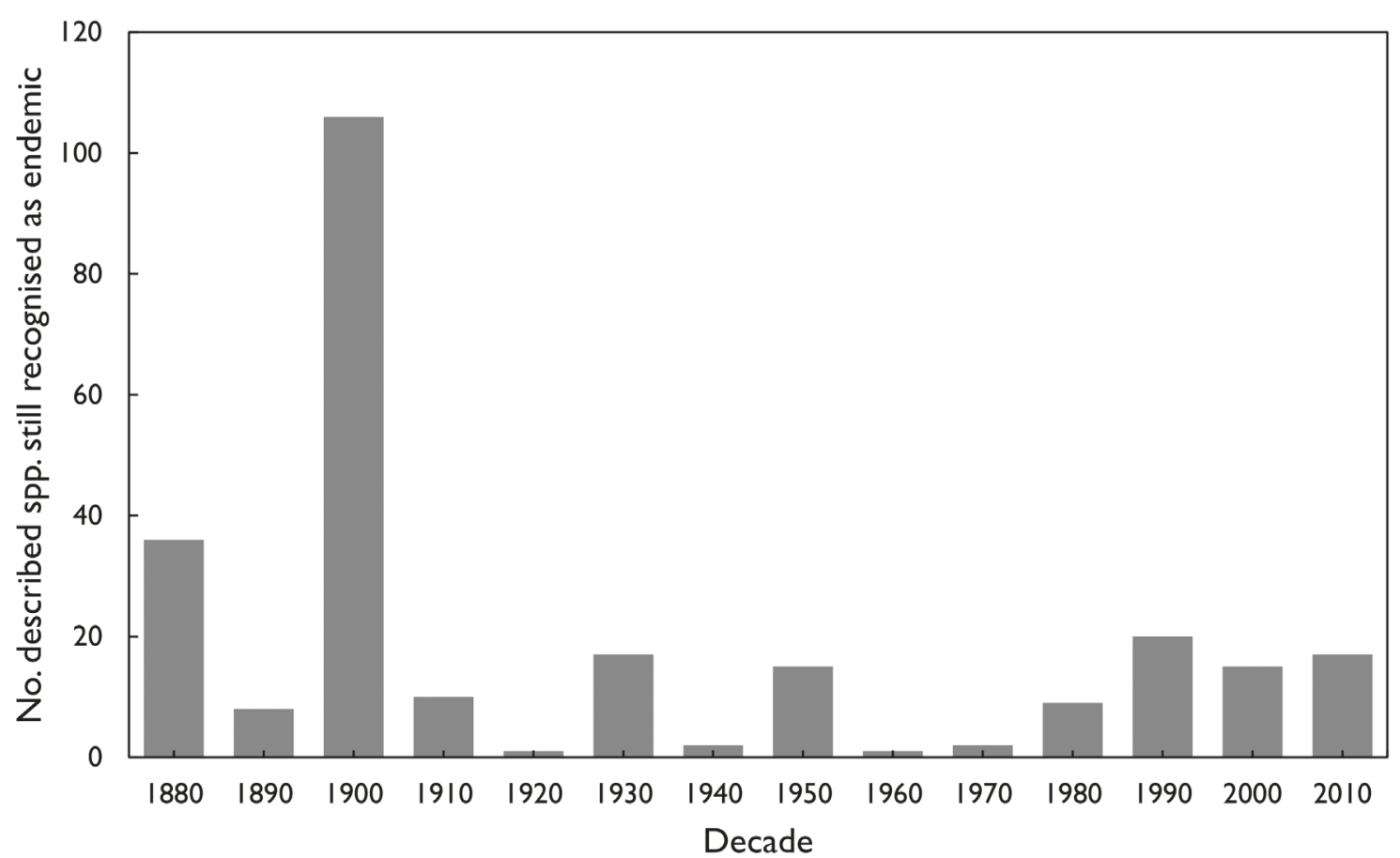

B

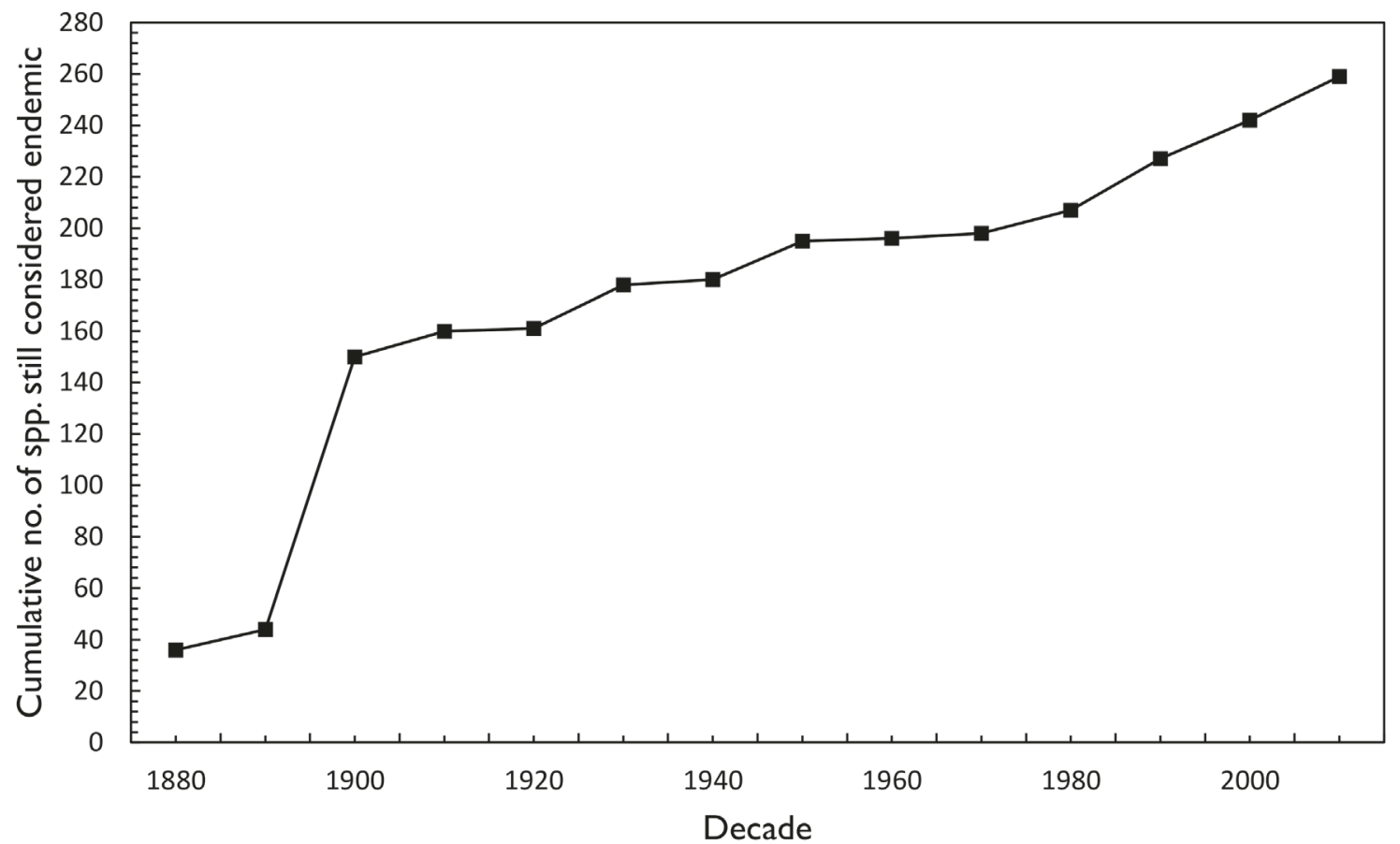

FIGURE 2 Date of description of species still recognised as endemic to Christmas Island. A) Number of species (still recognised as endemic) described per decade; B) Cumulative number of such species. 
1908 and was considered extinct in assessments in 1908 (Andrews 1909) and in the 1930s (Gibson-Hill 1947f). However, two individuals were recorded in 1958 and two more were collected in the mid-1980s (Eldridge et al. 2014), although it has not been reported since. The Christmas Island blind snake Ramphotyphlops exocoeti has been reliably recorded only six times since 1901, and only once since 1986 (Maple et al. 2012). In 2004 one of the Christmas Island jewel weevils, Rhyncolobus rossi, was 'rediscovered' when a single specimen was collected for the first time since Andrew's original collection in 1897-98 (Surman 2004). The conservation status (or even whether extant or extinct) of such nebulous species may be particularly difficult to assess.

Nonetheless, some precautionary consideration of conservation status for poorly-known endemic species is justifiable, given the range and intensity of threats continuing to affect biodiversity on the island, the demonstrated decline and extinction of many well-known endemic species, and the retrospectivelyrecognised rate of extinctions of poorly-known species on many other islands (Régnier et al. 2009, 2015a,b). In the absence of evidence to the contrary, most or all endemic terrestrial species on Christmas Island should qualify (and hence be listed, at national and global scales) as Endangered under IUCN categories $\mathrm{B} 1 \mathrm{ab}(\mathrm{ii}, \mathrm{iii}, \mathrm{v})+2 \mathrm{ab}(\mathrm{ii}, \mathrm{iii}, \mathrm{v})$ - that is, with extent of occurrence between 100 and $5,000 \mathrm{~km}^{2}$ (an actual value of at most $137 \mathrm{~km}^{2}$ ) [=B1], area of occupancy between 10 and $500 \mathrm{~km}^{2}$ (an actual value of at most 137 $\mathrm{km}^{2}$, but probably appreciably less given the extent of habitat lost to mining and other development) [=B2], occurrence at between one and five locations (an actual value of one) $[=\mathrm{a}]$, and an inferred or projected continuing decline $[=\mathrm{b}]$ in area of occupancy (reflecting distributional contraction due to ongoing habitat loss and likely exclusion of the species from areas with crazy ant super-colonies, or coral bleaching, or other threats) [=ii], area, extent and/or quality of habitat (reflecting ongoing loss of habitat and decline in habitat quality due to those same threats) [=iii], and number of mature individuals (due to those same threats) $[=\mathrm{v}]$. This categorisation may not fit for subterranean species (for which habitat loss or degradation may not have occurred, or may not be continuing), although these are likely to have been affected by other threats arising from the island's settlement and resource use, especially groundwater extraction. The assessment that the majority of Christmas Island's endemic species most likely qualify as Endangered under IUCN categories Blab(ii,iii,v)+2ab(ii,iii,v) matches a comparable assessment of endemic invertebrates on the Azores (Cardoso et al. 2011a). An alternative approach may be to list many of these poorly-known endemic species as Data Deficient. However such a categorisation is not available at the national level under Australia's environmental legislation, and provides little conservation security or obligation for management prioritisation, and for most criteria (area of occupancy, extent of occurrence, number of locations, and - less so - likelihood of continuing decline) there is sufficient information to exclude the need to use the Data Deficient category.

Another option for providing some bolstered conservation security for some Christmas Island endemic species is by considering these species as short-range endemics (Harvey et al. 2011) and using the island's existing governance matrix (which includes applicability of some Western Australian law, including in some environmental matters) to allow for some explicit protection of such species under Western Australian legislation (Environmental Protection Authority 2009). Such listing is not currently available under national or global conservation status processes, strategies or law. This approach may be particularly applicable for Christmas Island's endemic subterranean fauna, with comparable species in Western Australia a particular focus for listing and protection as shortrange endemics. Most Christmas Island endemic species would readily qualify for such listing, as they meet the legislated criteria of being terrestrial and freshwater invertebrates with distributions of less than $10,000 \mathrm{~km}^{2}$.

In addition to consideration of such listing, a range of other measures should be taken to help maintain the endemic species, and hence the biodiversity significance of this island. Given that introduced species are the major cause of extinctions in island species globally (Sax and Gaines 2008; Medina et al. 2011; Harper and Bunbury 2015; Doherty et al. 2016; McCreless et al. 2016), a priority for conservation of Christmas Island's endemic biodiversity is to bolster the current weak biosecurity efforts and standards (Beeton et al. 2010).

A reference collection of all endemic species (or at least images of all endemic species) should be established and maintained, to help raise awareness of the existence of poorly-known endemic species, and as a catalyst for reporting records of them: such a catalogue of images is currently being compiled for endemic lepidopteran species (C. Pink pers. comm.). Targeted surveys should be undertaken for endemic species, particularly those that have not been recorded for many decades. Targeted surveys are also warranted more broadly for those taxonomic groups that have hitherto been subjected to little sampling. Research should be conducted into poorly-known endemic species that are likely to be most imperilled, with such studies seeking especially to assess population size, distribution, threats and management needs; and such assessment should then be repeated regularly via monitoring to evaluate population trends and responses to management. Many of the species we considered here to be confirmed or probable endemics may be of uncertain taxonomic status, with little taxonomic scrutiny since original collections more than 100 years ago. For such species, taxonomic re-assessment may be now long overdue. 
Many of the poorly-known endemic species that have been unrecorded for more than 50 years have no precise locational data (often other than 'Christmas Island'). This renders such species difficult to consider in assessments of possible impacts of proposed developments and in other spatial conservation planning exercises for the island. To be able to plan for their conservation, more knowledge about these species is required. Establishing how to identify all these endemic species is a first essential step. Only then will it be possible to start documenting systematic information on geographical distribution, habitat preferences, foods sources, life-cycles, etc. Most of the endemic species are invertebrates and many of these are likely to have been severely affected by supercolonies of crazy ants, with some perhaps also affected by the extensive application of insecticides used as temporary control measures for these supercolonies. It is most likely that populations of many endemic invertebrate species will have been lost from these supercolony areas, but may have persisted in those areas that have never been affected by supercolonies. Because of high-resolution mapping, these areas (that have not yet been exposed to supercolonies of crazy ants) have been well-defined (Boland et al. 2011), and such areas should now be prioritised for survey for 'lost' endemic invertebrates and excluded from ongoing development.

There have been some notable examples of consideration of poorly-known endemic species in conservation management on the island, and some examples of inadequate consideration. During consideration of the introduction of a parasitoid wasp as a biocontrol agent for the scale insects that are the resource base for development of super-colonies of crazy ants, managers inventoried hemipterans already present on the island, assessed which were likely to be endemic and evaluated the likely impact of the proposed introduction of parasitoids on those species (Neumann et al. 2016, 2018), although even in this case, our review indicates that that previous scrutiny did not recognise all endemic hemipterans. In contrast, other than for two species of high profile charismatic crabs, poorly-known and endemic species were not considered at all in an assessment of the likely impacts of broadscale application of insecticides to control yellow crazy ants (Stork et al. 2014), or a recently failed application for further forest clearing to facilitate new mining operations (Frydenberg 2018).

Some other conservation measures taken for the threatened vertebrates have probably also provided some benefit for poorly-known endemic species, as is reportedly the case for biodiversity on other islands (Aslan et al. 2015). These measures include the control of yellow crazy ants, some environmental constraints on mining and other developments, and the establishment of a national park encompassing the majority of the island. However, other substantial management investments targeting threats to threatened endemic vertebrates (notably a current program to control feral cats) are unlikely to provide protection also to imperilled endemic invertebrate or plant species; and the establishment of a national park, while providing a bulwark against mining and vegetation clearance, is unlikely of itself to have prevented the impacts of some other threats (notably pests, disease and weeds) to endemic species.

Because of very variable sampling comprehensiveness among island groups, it is challenging to compare the number and fate of endemic species we report here for Christmas Island with those of other islands. Albeit with many caveats (notably including variation among islands in the extent of sampling), we list some comparisons with the two other biodiversity-rich oceanic islands of Australia, Lord Howe Island (and its satellite islands) and Norfolk Island (and its satellite islands), with information for these two other island groups sourced mainly from Cassis et al. (2003) and Department of Environment and Climate Change (NSW) (2007) for the Lord Howe Island group and Neuweger et al. (2001), Cogger et al. (2006), Mills (2009) and Director of National Parks (2010) for the Norfolk Island group. There are several notable features of this comparison. Although the number of known endemic invertebrate and plant species on Christmas Island is substantial, comparable tallies on Lord Howe and Norfolk are much higher, notwithstanding their smaller size: and the number of endemic genera is appreciably higher on Lord Howe and Norfolk. In contrast, Christmas Island has many more endemic vertebrate species. The extinction of endemic vertebrates, but relative security of endemic plants, is a notable common feature of the three islands. However, the extent of extinction or persistence of endemic invertebrates is difficult to assess on all of these islands.

\section{ACKNOWLEDGEMENTS}

We thank Jeff Clausen, Claire Davies, Volker Framenau, Alistair Graham, John Hueston, Vince Kessner, Ian McAllan, Ruth Marr, Nicholas Milly, Lisa Nichols, Max Orchard, Kent Retallick, Chris Surman and Azmi Yon for their invaluable field and laboratory contributions in the early stages of this endeavour. Andy Austin (University of Adelaide), Tim New (La Trobe University), Robert Mesibov (Ulverstone, Tas), Massimo Olmi (Tuscia University, Italy), Max Orchard (Coles Bay, Tas), Gustav Paulay (Florida Museum of Natural History, USA), Caitlyn Pink and Alasdair Grigg (Parks Australia), Nick Stevens (Stantec Australia), Melissa Titelius (Western Australian Museum), Mark Heath, Ken Walker (Museums Victoria) and Herbert Zettel (Naturhistorisches Museum, Germany) kindly shared their expertise with particular species and groups. We thank also Mark Harvey for his editorial assistance. JW's contribution to this research was supported by the Australian Government's National Environmental Science Programme (Threatened Species Recovery Hub). 


\section{REFERENCES}

Abbott, K.L. (2006). Spatial dynamics of supercolonies of the invasive yellow crazy ant, Anoplolepis gracilipes, on Christmas Island, Indian Ocean. Diversity and Distributions 12: 101-110.

Adler, G.H. (1994). Avifaunal diversity and endemism on tropical Indian Ocean islands. Journal of Biogeography 21: 85-95.

Ahyong, S.T. (2014). Stomatopod Crustacea of Christmas Island and the Cocos (Keeling) Islands. Raffles Bulletin of Zoology. Supplement 30: 246-254.

Alcover, J.A., Campillo, X., Macias, M. and Sans, A. (1998). Mammal species of the world: additional data on insular mammals. American Museum Novitates 3248: 1-29.

Ali, J.R. and Aitchison, J.C. (2020). Time of re-emergence of Christmas Island and its biogeographical significance. Palaeogeography, Palaeoclimatology, Palaeoecology 537: 109396

Allen, G.R., Steene, R. and Orchard, M. (2007). Fishes of Christmas Island. Christmas Island Natural History Association: Christmas Island.

Amori, G. and Clout, M. (2003). Rodents on islands: a conservation challenge. In: Singleton, G.R., Hinds, L.A., Krebs, C.J. and Spratt, D.M. (eds). Rats, mice and people: rodent biology and management. pp. 63-68. Australian Centre for International Agricultural Research: Canberra.

Andrew, P., Cogger, H., Driscoll, D., Flakus, S., Harlow, P., Maple, D., Misso, M., Pink, C., Retallick, K., Rose, K., Tiernan, B., West, J. and Woinarski, J.C.Z. (2018). Somewhat saved: a captive breeding program for two endemic Christmas Island lizard species, now extinct in the wild. Oryx 52: 171-174.

Andrews, C.W. (1900a). Land crustacea. In: Andrews, C.W. (ed). A monograph of Christmas Island (Indian Ocean). pp. 163-165. British Museum Trustees: London.

Andrews, C.W. (1900b). Mammalia. In: Andrews, C.W. (ed). A monograph of Christmas Island (Indian Ocean) - physical features and geology, with descriptions of the fauna and flora by numerous contributors. pp. 22-37. British Museum Trustees: London.

Andrews, C.W. (ed.) (1900c). A monograph of Christmas Island (Indian Ocean) - physical features and geology, with descriptions of the fauna and flora by numerous contributors. British Museum Trustees: London.

Andrews, C.W. (1909). On the fauna of Christmas Island. Proceedings of the Zoological Society of London 79: 101-103.

Aslan, C., Holmes, N., Tershy, B., Spatz, D. and Croll, D.A. (2015). Benefits to poorly studied taxa of conservation of bird and mammal diversity on islands. Conservation Biology 29: 133-142.

Baehr, M. (2008). A new cavernicolous and eyeless species of the genus Lymnastis from Christmas Island, Australia (Insecta: Coleoptera: Carabidae: Bembidiinae). Records of the Western Australian Museum 24: 199-203.

Balss, H. (1934). Die krabben der reise JW Harms' nach der Christmas-Insel und dem Malaiischen Archipel. Zoologischer Anzeiger 106: 225-237.

Beeton, B., Burbidge, A., Grigg, G., Harrison, P., How, R., Humphreys, B., McKenzie, N. and Woinarski, J. (2010). Final report of the Christmas Island Expert Working Group to the Minister for Environment Protection. Heritage and the Arts. Canberra.
Belles, X. and Lawrence, J.F. (1990). Notes on the genus Neoptinus Gahan (=Ptinosphaerus Belles and Lawrence) (Coleoptera: Ptinidae). Australian Entomologist 17: 61-63.

Belokobylskij, S. (2006). Neoheterospilus gen. n. a new genus of the tribe Heterospilini (Hymenoptera: Braconidae, Doryctinae) with highly modified ovipositor and a worldwide distribution. Insect Systematics and Evolution 37: 149-178.

Belokobylskij, S.A., Iqbal, M. and Austin, A.D. (2004). Systematics, distribution and diversity of the Australian doryctine wasps (Hymenoptera, Braconidae, Doryctinae). Records of the South Australian Museum. Monograph Series 8: 1-150.

Bickel, D.J. (1994). The Australian Sciapodinae (Diptera: Dolichopodidae), with a review of the Oriental and Australasian faunas, and a world conspectus of the subfamily. Records of the Australian Museum. Supplement 21: $1-394$.

Bieler, R., Bouchet, P., Dijkstra, H., Faber, M., Finn, J., Garcia-Alvarez, O., Gofas, S., La Perna, R., Marshall, B., Moretzsohn, F., Neubauer, T.A., Rosenberg, G., Sartori, A.F., Schneider, S., Taylor, J., ter Poorten, J.J. and Vos, C. (2018). WoRMS Mollusca: MolluscaBase (2017) (version 2018-01-01). Naturalis, Leiden, the Netherlands. www. catalogueoflife.org/col

Blackburn, T.M., Cassey, P., Duncan, R.P., Evans, K.L. and Gaston, K.J. (2004). Avian extinction and mammalian introductions on oceanic islands. Science 305: 1955-1958.

Blackman, V.H. (1900). Fungi. In: Andrews, C.W. (ed). A monograph of Christmas Island (Indian Ocean). pp. 198200. British Museum Trustees: London.

Boland, C.R.J., Smith, M.J., Retallick, K., Reeves, R., Tiernan, B., Maple, D., Humphries, C., Barr, R., Napier, F. and Taylor, R. (2011). Heli-baiting using low concentration fipronil to control invasive yellow crazy ant supercolonies on Christmas Island, Indian Ocean. In: Veitch, C.R., Clout, M.N. and Towns, D.R. (eds). Island invasives: eradication and management. pp. 152-156. IUCN: Gland, Switzerland.

Borissova, I. (1994). Seafloor morphology and tectonics of the Christmas Island area, Indian Ocean. Australian Geological Survey Organisation: Canberra.

Bouček, Z. (1988). Australasian Chalcidoidea (Hymenoptera): A Biosystematic Revision of Genera and Fourteen Families, with a Reclassification of Species. CAB International: Wallingford, UK.

Boulenger, G.A. (1887). Report on a zoological collection made by the officers of H.M.S. "Flying Fish" at Christmas Island, Indian Ocean. III. Reptiles. Proceedings of the Zoological Society London 1887: 516-517.

Boulenger, G.A. (1889). On the reptiles of Christmas Island. Proceedings of the Zoological Society London 56: 534-536.

Bremer, H.J. (2007). Revision der Gattung Amarygmus Dalman sowie verwandter Gattungen (Coleoptera: Tenebrionidae: Amarygmini). XLV. Neu- und Nachbeschreibungen von Amarygmus-Arten der orientalischen Region. Stuttgarter Beiträge zur Naturkunde Serie A (Biologie) 707: 1-48.

Brooke, M.L., Hilton, G.M. and Martins, T.L.F. (2007). Prioritizing the world's islands for vertebrate-eradication programmes. Animal Conservation 10: 380-390.

Brown, W.C. (1991). Lizards of the genus Emoia (Scincidae) with observations on their evolution and biogeography. Memoirs of the Californian Academy of Sciences 15: 1-94. 
Bruce, A.J. and Davie, P.J.F. (2006). A new anchialine shrimp of the genus Procaris from Christmas Island: the first occurrence of the Procarididae in the Indian Ocean (Crustacea: Decapoda: Caridea). Zootaxa 1238: 23-33.

Budde-Lund, G. (1906). Die Land isopoden der deutschen Südpolar-Expedition, 1901-03, mit Diagnosen verwandter Arten. Deutsche Südpolar Expedition 1901-1903 9: 69-92.

Burks, R.A., Masner, L., Johnson, N.F. and Austin, A.D. (2013). Systematics of the parasitic wasp genus Oxyscelio Kieffer (Hymenoptera, Platygastridae sl), Part I: Indo-Malayan and Palearctic fauna. ZooKeys 1-263.

Burton, M. (1959). Sponges. In: Scientific Reports. John Murray Expedition 1933-34. pp. 151-281. British Museum (Natural History): London.

Butler, A.G. (1887). Report on a zoological collection made by the officers of H.M.S. "Flying Fish" at Christmas Island, Indian Ocean. VII. Lepidoptera. Proceedings of the Zoological Society London 1887: 522-523.

Butler, A.G. (1889). On the Lepidoptera of Christmas Island. Proceedings of the Zoological Society London 56: 542-555.

Butler, A.G. (1900). Lepidoptera Rhopalocera. In: Andrews, C.W. (ed). A monograph of Christmas Island (Indian Ocean). pp. 60-63. British Museum Trustees: London.

Butz, M. (2004). National recovery plan for Tectaria devexa. Department of Environment and Heritage: Canberra.

Calman, W.T. (1909). On Decapod Crustacea from Christmas Island. Proceedings of the Zoological Society London 1909: 703-713.

Campbell, T.G. (1968). Entomological survey of Christmas Island (Indian Ocean) with special reference to the insects of medical, veterinary, agricultural and forestry significance. CSIRO Division of Entomology: Canberra.

Cardoso, P., Borges, P.A.V., Triantis, K.A., Ferrández, M.A. and Martín, J.L. (2011a). Adapting the IUCN Red List criteria for invertebrates. Biological Conservation 144: 2432-2440.

Cardoso, P., Erwin, T.L., Borges, P.A. and New, T.R. (2011b). The seven impediments in invertebrate conservation and how to overcome them. Biological Conservation 144: 2647-2655.

Carson, H.L. and Wheeler, M.R. (1973). A new crab fly from Christmas Island, Indian Ocean (Diptera: Drosophilidae). Pacific Insects 15: 199-208.

Cassis, G. and Gross, B.F. (2002). Hemiptera: Heteroptera (Pentatomorpha). ABRS and CSIRO Publishing: Melbourne.

Cassis, G. and Gross, G.F. (1995) Hemiptera: Coleorrhyncha to Cimicomorpha. ABRS and CSIRO Publishing: Canberra.

Cassis, G., Houston, W.W.K., Weir, T.A. and Moore, B.P. (1992). Scarabaeoidea. Zoological Catalogue of Australia, vol 9. Australian Government Printing Service: Canberra.

Cassis, G., Meades, L., Harris, R., Reid, C., Carter, G., Wilkie, L. and Jeffreys, E. (2003). Lord Howe Island Terrestrial Invertebrate Biodiversity and Conservation, Report to the NSW National Parks and Wildlife Service: Sydney.

Cayzer, L.W., Crisp, M.D. and Telford, I.R.H. (2000). Revision of Pittosporum (Pittosporaceae) in Australia. Australian Systematic Botany 13: 845-902.

Chandra, K. and Kushwaha, S. (2014). Ground bugs (Hemiptera: Lygaeidae) of Madhya Pradesh, with their distribution in India. Munis Entomology and Zoology 9: 535-539.

Chasen, F.N. (1933a). Notes on the birds of Christmas Island, Indian Ocean. Bulletin of the Raffles Museum 8: 55-87.
Chasen, F.N. (1933b). Notes on the fauna of Christmas Island, Indian Ocean. Introduction. Bulletin of the Raffles Museum 8: $51-54$.

Chasen, F.N. (1935). A handlist of Malaysian birds. Bulletin of the Raffles Museum 11: 1-389.

Chasen, F.N. (1940). A handlist of Malayan mammals: a systematic list of the mammals of the Malay Peninsula, Sumatra, Borneo and Java, including the adjacent small islands. Bulletin of the Raffles Museum 15: 1-209.

Christidis, L. and Boles, W.E. (2008). Systematics and taxonomy of Australian birds, CSIRO Publishing: Melbourne.

Clark, A.H. (1911). A new unstalked crinoid from Christmas Island. Annals and Magazine of Natural History Series 8, 7: 644-645.

Claussen, J. (2005). Native plants of Christmas Island. Australian Biological Resources Study: Canberra.

Cockerell, T.D.A. (1909). Descriptions and records of bees.XXII. Annals and Magazine of Natural History. Series 8, 4(22): 309-317.

Cogger, H. (2006). National Recovery Plan for Lister's Gecko Lepidodactylus listeri and the Christmas Island Blind Snake Typhlops exocoeti. Department of the Environment and Heritage: Canberra.

Cogger, H., Muir, G. and Shea, G. (2006). A survey of the terrestrial reptiles (Christinus guentheri and Oligosoma lichenigera) of Norfolk Island - March 2005: 2. A qualitative assessment of the relative abundance of the Norfolk and Lord Howe Island reptiles. Australian Government Department of the Environment, Water, Heritage and the Arts: Canberra.

Cogger, H. and Sadlier, R. (1981). The terrestrial reptiles of Christmas Island, Indian Ocean. Australian Museum: Sydney.

Cogger, H., Sadlier, R. and Cameron, E. (1983). The terrestrial reptiles of Australia's island territories. Australian National Parks and Wildlife Service: Canberra.

Cogger, H.G. (2014). Reptiles and amphibians of Australia. CSIRO Publishing: Collingwood.

Colwell, R.K., Dunn, R.R. and Harris, N.C. (2012). Coextinction and persistence of dependent species in a changing world. Annual review of Ecology, Evolution, and Systematics 43: 183-203.

Corbet, S. and Pendlebury, H.M. (1932). A revision of the Indo-Australian forms of the genus Eurema with special reference to the Malaysian forms. Bulletin of the Raffles Museum 7: 143-193.

CSIRO Division of Entomology (1990). Entomological Survey of Christmas Island. Report to the Australian National Parks and Wildlife Service. Canberra. CSIRO: Canberra.

Dall, W.H. (1920). Annotated list of the recent Brachiopoda in the collection of the United States National Museum, with descriptions of thirty-three new forms. Proceedings of the United States National Museum 57: 261-377.

Daniels, G. (2012). A replacement name and new combination for Laphria nigrocaerulea Kirby, 1889 (Diptera: Asilidae: Laphriinae). Australian Entomologist 39: 188.

Darwin, C. (1845). Journal of researches into the natural history and geology of the countries visited during the voyage of H.M.S. Beagle round the world. Second edition. John Murray: London.

Davie, P.J.F. (2002). Crustacea: Malacostraca: Eucarida (part 2): Decapoda - Anomura, Brachyura, ABRS and CSIRO Publishing: Canberra. 
Davie, P.J.F. and Ng, P.K.L. (2012). Two new species of Orcovita (Crustacea: Decapoda: Brachyura: Varunidae) from anchialine caves on Christmas Island, eastern Indian Ocean. Raffles Bulletin of Zoology 60: 57-70.

Davie, P.J.F. and Ng, P.K.L. (2013). A review of Chiromantes obtusifrons (Dana, 1851)(Decapoda: Brachyura: Sesarmidae), with descriptions of four new sibling-species from Christmas Island (Indian Ocean), Guam and Taiwan. Zootaxa 3609: 1-25.

Davies, C. and Beckley, L.E. (2010). Zooplankton from the inshore waters of Christmas Island (Indian Ocean) with reference to larvae of the red land crab, Gecarcoidea natalis. Journal of the Royal Society of Western Australia 93: 43-50.

Deeming, J.C. (1964). A remarkable new species of Leptocera from Christmas Island and New Guinea (Dipt. Sphaeroceridae). Opuscula Entomologica 29: 164-167.

Dendy, A. (1887). Report on a zoological collection made by the officers of H.M.S. "Flying Fish" at Christmas Island, Indian Ocean. IX. Porifera. Proceedings of the Zoological Society London 1887: 524-526.

Department of Environment and Climate Change (NSW) (2007). Lord Howe Island Biodiversity Management Plan. Department of Environment and Climate Change (NSW): Sydney.

Diniz-Filho, J.A.F., De Marco Jr, P. and Hawkins, B.A. (2010). Defying the curse of ignorance: perspectives in insect macroecology and conservation biogeography. Insect Conservation and Diversity 3: 172-179.

Diniz-Filho, J.A.F., Loyola, R.D., Raia, P., Mooers, A.O. and Bini, L.M. (2013). Darwinian shortfalls in biodiversity conservation. Trends in Ecology and Evolution 28: 689-695.

Director of National Parks (2010). Norfolk Island region threatened species recovery plan. Department of the Environment Water Heritage and the Arts: Canberra.

Director of National Parks (2014). Christmas Island National Park Management Plan 2014-2024. Parks Australia: Canberra.

Dirsh, V.M. and Uvarov, B.P. (1953). Preliminary diagnoses of new genera and new synonymy in Acrididae. Tijdschrift voor Entomologie 96: 231-237.

Distant, W.L. (1901). Rhynchotal notes. XI. Heteroptera: Fam. Lygaeidae. Annals of the Magazine and Natural History 7: 464-486.

Doherty, T.S., Glen, A.S., Nimmo, D.G., Ritchie, E.G. and Dickman, C.R. (2016). Invasive predators and global biodiversity loss. Proceedings of the National Academy of Sciences 113: 11261-11265.

Domínguez de Toledo, L.S. and Castellano, M.A. (1996). A revision of the genera Radiigera and Pyrenogaster. Mycologia 88: 863-884.

Done, T.J. and Marsh, L. (2000). Reef-building corals of Christmas Island. Records of the Western Australian Museum. Supplement 59: 79-81.

Donisthorpe, H.J. (1935). The ants of Christmas Island. Annals and Magazine of Natural History 15: 629-636.

Doyen, J.T., Matthews, E.G. and Lawrence, J.F. (1989). Classification and annotated checklist of the Australian genera of Tenebrionidae (Coleoptera). Invertebrate Systematics 3: 229-260.

Du Puy, D. (1988). Mapping of Christmas Island native and endemic plants with limited distributions. Royal Botanic Gardens: Kew.
Du Puy, D.J. (1993). Christmas Island. Flora of Australia 50: $1-42$.

Durham, H.E. (1908). Notes on Nagana and on some Haematozoa observed during my travels. Parasitology 1: 227-235.

Easton, E.G. (1984). Earthworms (Oligochaeta) from islands of the south-western Pacific, and a note on two species from Papua-New Guinea. New Zealand Journal of Zoology 11: 111-128.

Edwards, F.W. (1927). Mosquito Notes VI. Bulletin of Entomological Research 17: 102-103.

Eldridge, M.D.B., Meek, P.D. and Johnson, R.N. (2014). Taxonomic uncertainty and the loss of biodiversity on Christmas Island, Indian Ocean. Conservation Biology 28: 572-579.

Environmental Protection Authority (2009). Guidance for the assessment of environmental factors (in accordance with the Environmental Protection Act 1986). Sampling of short range endemic invertebrate fauna for environmental impact assessment in Western Australia. Environmental Protection Authority: Perth.

Evenhuis, N.L. (2005). New Cymatopus (Diptera: Dolichopodidae) from Fiji and related areas, with notes on described species. Bishop Museum Occasional Papers 82: $31-45$.

Farran, G.P. (1911). Plankton from Christmas Island, Indian Ocean, I. On Copepoda of the family Corycaeidae. Proceedings of the Zoological Society of London 1911: 282-296.

Farran, G.P. (1913). Plankton from Christmas Island, Indian Ocean. - II. On Copepoda of the genera Oithona and Paroithona. Proceedings of the Zoological Society of London 1913: 181-193.

Fennah, R.G. (1954). The higher classification of the family Issidae (Homoptera: Fulgoroidea) with descriptions of new species. Transactions of the Royal Entomological Society of London 105: 455-474.

Fennah, R.G. (1964). New species of Ugyops (Fulgoroidea: Delphacidae) from south America and south-east Asia. Bulletin of the British Museum (Natural History) Zoology 15: 117-143.

Ferrari, F.D. and Böttger, R. (1986). Sexual dimorphism and a sex-limited polymorphism in the copepod Paroithona pacifica Nishida, 1985 (Cyclopoida: Oithonidae) from the Red Sea. Proceedings of the Biological Society of Washington 99: 274-285.

Fletcher, M.J. (2008). A key to the genera of Ricaniidae (Hemiptera: Fulgoromorpha) recorded in Australia with notes on the Australian fauna, including a new species of Epithalamium Kirkaldy. Australian Journal of Entomology 47: 107-120.

Fletcher, M.J. and Dai, W. (2013). The genus Hishimonus Ishihara in Australia (Hemiptera: Cicadellidae: Deltocephalinae: Opsiini) including description of three new species. Memoirs of the Queensland Museum Nature 58: 421-431.

Framenau, V.W. and Thomas, M.L. (2008). Ants (Hymenoptera: Formicidae) of Christmas Island (Indian Ocean): identification and distribution. Records of the Western Australian Museum 25: 45-85.

Framenau, V.W. and Waldock, J.M. (2006). The spiders (Arachnida, Araneae) of Christmas Island. Department of Terrestrial Invertebrates, Western Australian Museum: Welshpool. 
Frank, J.H. (1988). Paederus, sensu lato (Coleoptera: Staphylinidae): an index and review of the taxa. Insecta Mundi 2: 97-159.

Frydenberg, J. (2018). Statement of Reasons for Decision not to Approve the taking of an action under the Environment Protection and Biodiversity Conservation Act 1999. Proposal 2016-7779. Department of the Environment and Energy: Canberra.

Fujita, Y., Davie, P.J.F. and Ng, P.K.L. (2015). A new stygobitic prawn of the genus Macrobrachium Spence Bate, 1864, from anchialine caves in Christmas Island, Indian Ocean; with a rediagnosis of $M$. miyakoense Komai and Fujita, 2005 (Crustacea: Decapoda: Caridea: Palaemonidae). Raffles Bulletin of Zoology 63: 610-625.

Gahan, C.J. (1889). On the Coleoptera of Christmas Island. Proceedings of the Zoological Society London 56: 538-541.

Garnett, S.T., Szabo, J.K. and Dutson, G. (2011). The action plan for Australian birds 2010. CSIRO Publishing: Collingwood.

Gates, G.E. (1935). On some earthworms from East Perak and Christmas Island. Bulletin of the Raffles Museum 10: 80-95.

Gauld, I.D. (1977). A revision of the Ophioninae (Hymenoptera: Ichneumonidae) of Australia. Australian Journal of Zoology Supplementary Series 49: 1-112.

Gepp, A. and Gepp, E.S. (1905). Some crytpogams from Christmas Island. Journal of Botany 43: 337-344.

Gibbons, D., Morrissey, C. and Mineau, P. (2015). A review of the direct and indirect effects of neonicotinoids and fipronil on vertebrate wildlife. Environmental Science and Pollution Research 22: 103-118.

Gibson-Hill, C. (1947a). Field notes on the terrestrial crabs. Bulletin of the Raffles Museum 18: 43-52.

Gibson-Hill, C. (1947b). The terrestrial reptiles. Bulletin of the Raffles Museum 18: 81-86.

Gibson-Hill, C.A. (1947c). Contributions to the natural history of Christmas Island, in the Indian Ocean. Bulletin of the Raffles Museum 18: 6-7.

Gibson-Hill, C.A. (1947d). Isoptera. Bulletin of the Raffles Museum 18: 56-57.

Gibson-Hill, C.A. (1947e). Lepidoptera (Rhopalocera). Bulletin of the Raffles Museum 18: 74-80.

Gibson-Hill, C.A. (1947f). A note on the mammals of Christmas Island. Bulletin of the Raffles Museum 18: 166-167.

Gibson-Hill, C.A. (1947g). Notes on the birds of Christmas Island. Bulletin of the Raffles Museum 18: 87-165.

Gibson-Hill, C.A. (1949a). The birds of the Cocos-Keeling Islands. Ibis 91: 221-243.

Gibson-Hill, C.A. (1949b). The early history of Christmas Island, in the Indian Ocean. Journal of the Malayan Branch of the Royal Asiatic Society 22: 67-93.

Gibson-Hill, C.A. (1950). Notes on the insects taken on the Cocos-Keeling Islands. Bulletin of the Raffles Museum 22: 149-165.

Göllner-Scheiding, U. (1980). Revision der afrikanischen Arten sowie Bemerkungen zu weiteren Arten der Gattungen Leptocoris Hahn, 1833, und Boisea Kirkaldy, 1910 (Het. Rhopalidae). Deutsche Entomologische Zeitschrift 27: 103-148.

Gomes, S.R. and Thomé, J.W. (2004). Diversity and distribution of the Veronicellidae (Gastropoda: Soleolifera) in the Oriental and Australian biogeographical regions. Memoirs of the Queensland Museum 49: 589-601.
Gordon, I. (1935). On two new species from Christmas Island. Annals and Magazine of Natural History 10: 629-637.

Green, P.T. (1997). Red crabs in rain forest on Christmas Island, Indian Ocean: patterns of activity, density and biomass. Journal of Tropical Ecology 13: 17-38.

Green, P.T. (2014). Mammal extinction by introduced infectious disease on Christmas Island (Indian Ocean): the historical context. Australian Zoologist 37: 1-14.

Green, P.T. Claussen, J. and O’Dowd, D.J. (2010). Lost for a century: rediscovery of the endemic Ridley's jewel orchid, Zeuxine exilis Ridl. on Christmas Island, Indian Ocean. Gardens' Bulletin (Singapore) 62: 319-326.

Green, P.T., Lake, P.S. and O'Dowd, D.J. (1999). Monopolization of litter processing by a dominant land crab on a tropical oceanic island. Oecologia 119: 435-444.

Green, P.T., O’Dowd, D.J., Abbott, K.L., Jeffery, M., Retallick, K. and Mac Nally, R. (2011). Invasional meltdown: invaderinvader mutualism facilitates a secondary invasion. Ecology 92: $1758-1768$.

Green, P.T., O’Dowd, D.J. and Lake, P.S. (2001). From resistance to meltdown: secondary invasion of an island rainforest. In: Ganeshaiah, K.N., Shankar, R.U. and Bawa, K.S. (eds). Tropical ecosystems. Structure, diversity and human welfare. pp. 451-455. Oxford and IBH: New Delhi.

Green, P.T. and O'Dowd, D.J. (2009). Management of invasive invertebrates: lessons from the management of an invasive alien ant. In: Clout, M.N. and P.A. Williams (eds). Invasive species management: a handbook of principles and techniques. pp. 153-172. Oxford University Press: New York.

Green, P.T., O'Dowd, D.J. and Lake, P.S. (1996). Long-term effects of the red crab (Gecarcoidea natalis) on rain forest regeneration and ecosystem processes on Christmas Island, Indian Ocean. Report to the Australian Nature Conservation Agency. Melbourne.

Green, P.T., O'Dowd, D.J. and Lake, P.S. (1997). Control of seedling recruitment by land crabs in rain forest on a remote oceanic island. Ecology 78: 2474-2486.

Green, P.T., O'Dowd, D.J. and Neumann, G. (2014). Application to release the microhymenopteran parasitoid Tachardiaephagus somervilli for the control of the invasive scale insect Tachardina aurantiaca on Christmas Island, Indian Ocean. https://www.environment.gov.au/resource/ crazy-ant-biocontrol

Grimes, K. (2001). Karst features of Christmas Island (Indian Ocean). Helictite 37: 41-58.

Guglielmone, A.A., Robbins, R.G., Apanaskevich, D.A., Petney, T.N., Estrada-Peña, A., Horak, I.G., Renfu Shao, R. and Barker, S.C. (2010). The Argasidae, Ixodidae and Nuttalliellidae (Acari: Ixodida) of the world: a list of valid species names. Zootaxa 2528: 1-28.

Guinot, D., Ng, N.K. and Moreno, P.A.R. (2018). Review of grapsoid families for the establishment of a new family for Leptograpsodes Montgomery, 1931, and a new genus of Gecarcinidae H. Milne-Edwards, 1837 (Crustacea, Decapoda, Brachyura, Grapsoidea MacLeay, 1838). Zoosystema 40: 547-605.

Hacker, H.H., Legrain, A. and Fibiger, M. (2008). Revision of the genus Acontia Ochsenheimer, 1816 and the tribus Acontiini Guenée, 1841 (Old World) (Lepidoptera: Noctuidae: Acontiinae) Esperiana Buchreihe zur Entomologie 14, 7-533. 
Hampson, G.F. (1900). Lepidoptera Phalaenae. In: Andrews, C.W. (ed). A monograph of Christmas Island (Indian Ocean). pp. 63-74. British Museum Trustees: London.

Hampson, G.F. (1910). Catalogue of the Lepidoptera Phalanae in the British Museum - 9, Taylor and Francis: London.

Hampson, G.F. (1912). Catalogue of the Lepidoptera Phalanae in the British Museum - 11, Taylor and Francis: London.

Hampson, G.F. (1926). Description of new genera and species of Lepidoptera, Phalaenae of the subfamily Noctuinae (Noctuidae) in the British Museum. Trustees of the British Museum (Natural History): London.

Harper, G.A. and Bunbury, N. (2015). Invasive rats on tropical islands: their population biology and impacts on native species. Global Ecology and Conservation 3: 607-627.

Harvey, M.S., Rix, M.G., Framenau, V.W., Hamilton, Z.R., Johnson, M.S., Teale, R.J., Humphreys, G. and Humphreys, W.F. (2011). Protecting the innocent: studying short-range endemic taxa enhances conservation outcomes. Invertebrate Systematics 25: 1-10.

Harvey, M.S. and West, P.L.J. (1998). New species of Charon (Amblypygi, Charontidae) from northern Australia and Christmas Island. Journal of Arachnology 26: 273-284.

Hayashi, T. (1997). Taxonomic notes on the genus Poeciliosomella Duda (Diptera, Sphaeroceridae) from the Oriental and Australasian regions, 1. P. pectiniterga (Deeming) and its allied new species. The Japan Society of Medical Entomology and Zoology 48: 49-54.

Hemsley, W.B. (1890). Report on the Botanical Collections from Christmas Island, Indian Ocean, made by Captain J. P. Maclear, Mr. J. J. Lister, and the Officers of H.M.S. 'Egeria'. Journal of the Linnean Society of London, Botany 25: 351-362.

Hicks, J., Rumpff, H. and Yorkston, H. (1990). Christmas Crabs. Christmas Island Natural History Association: Christmas Island.

Hill, R. (2004a). National Recovery Plan for the Christmas Island Goshawk Accipiter fasciatus natalis. Commonwealth of Australia: Canberra.

Hill, R. (2004b). National Recovery Plan for the Christmas Island Hawk-Owl Ninox natalis. Commonwealth of Australia: Canberra.

Hobbs, J.-P.A., Frisch, A.J., Ford, B.M., Thums, M., SaenzAgudelo, P., Furby, K.A. and Berumen, M.L. (2013). Taxonomic, spatial and temporal patterns of bleaching in anemones inhabited by anemonefishes. PLOS ONE 8: e70966.

Hobbs, J.A., Coker, D.J., Green, P.T., James, D.J., Humphreys, W.F., McAllan, A.W., Newman, S.J., Pratchett, M.S., Staeudle, T.M. and Whiting, S.D. (2014a). An annotated bibliography of the research on marine organisms and environments at Christmas Island and the Cocos (Keeling) Islands. Raffles Bulletin of Zoology. Supplement 30: 419-468.

Hobbs, J.A., Newman, S.J., Mitsopoulos, G.E.A., Travers, M.J., Skepper, C.L., Gilligan, J.J., Allen, G.R., Choat, H.J. and Ayling, A.M. (2014b). Checklist and new records of Christmas Island fishes: the influence of isolation, biogeography and habitat availability on species abundance and community composition. Raffles Bulletin of Zoology. Supplement 30: 184-202.

Hoernle, K., Hauff, F., Werner, R., van den Bogaard, P., Gibbons, A.D., Conrad, S. and Müller, R.D. (2011). Origin of Indian Ocean Seamount Province by shallow recycling of continental lithosphere. Nature Geoscience 4: 883-887.
Holmes, G. and Holmes, J. (2002). Conservation status of the Flora of Christmas Island, Indian Ocean. Canberra.

Hooper, J.N.A. and Wiedenmayer, F. (1994). Porifera. Zoological Catalogue of Australia, Volume 12. CSIRO Publishing: Melbourne.

Hull, F.M. (1944). Some flies of the Family Syrphidae in the British Museum (Natural History). Annals and Magazine of Natural History 11: 21-61.

Humphreys, W.F. (2014). Subterranean fauna of Christmas Island: habitats and salient features. Raffles Bulletin of Zoology. Supplement 30: 29-44.

Humphreys, W.F. and Eberhard, S. (2001). Subterranean fauna of Christmas Island, Indian Ocean. Helictite 37: 59-74.

Humphreys, W.F., Kornicker, L.S. and Danielopol, D.L. (2009). On the origin of Danielopolina baltanasi sp. $\mathrm{n}$. (Ostracoda, Thaumatocypridoidea) from three anchialine caves on Christmas Island, a seamount in the Indian Ocean. Crustaceana 82: 1177-1203.

Hurtado, L.A., Lee, E.J., Mateos, M. and Taiti, S. (2014). Global diversification at the harsh sea-land interface: mitochondrial phylogeny of the supralittoral isopod genus Tylos (Tylidae, Oniscidea). PLoS ONE 9: e94081.

Iredale, T. (1917). On some new species of marine Mollusca from Christmas Island, Indian Ocean. Journal of Molluscan Studies 12: 331-332.

Iwan, D., Ferrer, J. and Raś, M. (2010). Catalogue of the world Gonocephalum Solier, 1834 (Coleoptera, Tenebrionidae, Opatrini). Part 1. List of the species and subspecies. Annales Zoologici 60: 245-304.

Izzard, R.J. (1933). The Hemiptera of Christmas Island. The Annals and Magazine of Natural History 17(102): 577-600.

Jackson, S. and Groves, C. (2015). Taxonomy of Australian Mammals. CSIRO Publishing, Clayton South.

Jadwiszczak, A.S. and Wegrzynowicz, P. (2003). Catalogue of Coccinellidae. Part I - Epilachninae. Mantis: Olsztyn, Poland.

Jałoszyński, P. (2017). First record of Cephenniini on Christmas Island, with updated checklist of world Cephennomicrus species and summary of their distribution (Coleoptera, Staphylinidae, Scydmaeninae). Zootaxa 4227: 593-600.

James, D. (2005). Christmas Island Biodiversity Monitoring Programme: quarterly report for the period October to December 2004. Report to the Department of Finance and Administration. Department of Environment and Heritage: Christmas Island.

James, D. (2007). Christmas Island Biodiversity Monitoring Programme: summary report, December 2003 to April 2007. Department of Environment and Heritage: Canberra.

James, D. and Milly, N. (2006). A biodiversity inventory database for Christmas Island National Park. Department of Environment and Heritage: Canberra.

James, D.J. and McAllan, I.A.W. (2014). The birds of Christmas Island, Indian ocean: a review. Australian Field Ornithology, Supplement 31: 1-175.

Jeekel, C.A.W. (2001). A bibliographic catalogue of the Spirobolida of the Oriental and Australian Regions (Diplopoda). Myriapod Memoranda 4: 3-104.

Jeekel, C.A.W. (2006). Some notes on Diplopoda from Christmas Island. Myriapod Memoranda 9: 59-63.

Jetz, W., Thomas, G.H., Joy, J.B., Redding, D.W., Hartmann, K. and A.O. M. (2014). Global distribution and conservation of evolutionary distinctness in birds. Current Biology 24: 919-930. 
Johnson, I.R. and Wilson, P.R. (2018). A survey of butterflies (Lepidoptera) of Christmas island (Indian Ocean) in March 2017. The Australian Entomologist 45: 159-180.

Jordan, K. and Rothschild, N.C. (1908). Revision of the noncombed eyed Siphonaptera. Parasitology 1: 1-100.

Kallies, A. (2013). New and little known Brachodidae from tropical Asia and Papua New Guinea (Lepidoptera, Cossoidea). Zootaxa 3641, 241-259.

Keeling, P., Leander, B.S. and Simpson, A. (2009). Eukaryotes. Eukaryota, Organisms with nucleated cells. Version 28 October 2009. http://tolweb.org/Eukaryotes/3/2009.10.28

Kessner, V. (2006). Report on the March 2006 survey of land snails (Mollusca: Pulmonata) of Christmas Island, Indian Ocean. Christmas Island.

Kier, G., Kreft, H., Lee, T.M., Jetz, W., Ibisch, P.L., Nowicki, C., Mutke, J. and Barthlott, W. (2009). A global assessment of endemism and species richness across island and mainland regions. Proceedings of the National Academy of Sciences 106: $9322-9327$.

Kirby, W.F. (1889). On the insects (exclusive of Coleoptera and Lepidoptera) of Christmas Island. Proceedings of the Zoological Society London 1888: 546-555.

Kirby, W.F. (1900a). Hemiptera. In: Andrews, C.W. (ed). A monograph of Christmas Island (Indian Ocean). pp. 127-129. British Museum (Natural History), London.

Kirby, W.F. (1900b). Homoptera. In: Andrews, C.W. (ed). A monograph of Christmas Island (Indian Ocean). pp. 130-138. British Museum (Natural History), London.

Kirby, W.F. (1900c). Hymenoptera. In: Andrews, C.W. (ed). A monograph of Christmas Island (Indian Ocean). pp. 81-88. British Museum (Natural History), London.

Kirby, W.F. (1900d). Mallophaga. In: Andrews, C.W. (ed). A monograph of Christmas Island (Indian Ocean). p. 138. British Museum (Natural History), London.

Kirby, W.F. (1900e). Neuroptera. In: Andrews, C.W. (ed). A monograph of Christmas Island (Indian Ocean). pp. 139-141. British Museum (Natural History), London.

Kirby, W.F. (1900f). Orthoptera. In: Andrews, C.W. (ed). A monograph of Christmas Island (Indian Ocean). pp. 141-153. British Museum (Natural History), London.

Kirkpatrick, R. (1900). On the sponges of Christmas Island. Proceedings of the Zoological Society of London 1900: 127-141.

Kirkpatrick, R. (1910). On a remarkable Pharetronid sponge from Christmas Island. Proceedings of the Royal Society of London B, Series B 83: 124-133.

Knight, W.J. (1970). A revision of the genus Hishimonus Ishihara (Hom. Cicadellidae). Suomen Hyönteistieteellinen Aikakauskirja 36: 125-139.

Kocak, A.O. and Kemal, M. (2010). Lepidoptera of Thailand. CESA News 60: 1-186.

Kolibáč, J. (2013). Trogossitidae: A review of the beetle family, with a catalogue and keys. ZooKeys 366: 1-194.

Kondorosy, K. (2016). New synonyms in Oriental Geocorinae (Heteroptera: Lygaeidae). Folia Entomologica Hungarica 67: 11-14.

Koopman, K.F. (1973). Systematics of Indo-Australian pipistrelles. Periodicum Biologorum 75: 113-116.

Kormilev, N.A. (1983). New oriental aradid bugs in the collections of the British Museum (Natural History) (Insecta: Hemiptera). Journal of Natural History 17: 437-469.
Kornicker, L.S., Danielopol, D.L. and Humphreys, W.F. (2006). Description of the anchialine ostracod Danielopolina sp. cf. D. kornickeri from Christmas Island, Indian Ocean. Crustaceana 79: 77-88.

Kwak, M.L. (2018). Australia's vanishing fleas (Insecta: Siphonaptera): a case study in methods for the assessment and conservation of threatened flea species. Journal of Insect Conservation 22: 545-550.

Laidlaw, F.F. (1935). Notes on a collection of terrestrial Mollusca from Christmas Island. Bulletin of the Raffles Museum 10: 95-100.

Laseron, C.F. (1956a). The families Rissoinidae and Rissoidae (Mollusca) from the Solanderian and Dampierian zoogeographical provinces. Marine and Freshwater Research 7: 384-484.

Laseron, C.F. (1956b). The family Cerithiopsidae (Mollusca) from the Solanderian and Dampierian zoogeographical provinces. Marine and Freshwater Research 7: 151-182.

Laseron, C.F. (1958). The family Triphoridae (Mollusca) from northern Australia; also Triphoridae from Christmas Island (Indian Ocean). Marine and Freshwater Research 9: 569-658.

Lewis, J. (2011). A review of the species in the genus Cryptops Leach, 1815 from the Old World related to Cryptops (Cryptops) hortensis (Donovan, 1810) (Chilopoda, Scolopendromorpha). International Journal of Myriapodology 4: 11-50.

Li, Z. Xiao, H. and Huang, D.-W. (2013). Sirovena Bouček (Pteromalidae: Pireninae), a new member of the fig wasp community associated with Ficus microcarpa (Moraceae). Zootaxa 3619: 581-588.

Linnavuori, R. (1960). Homoptera: Cicadellidae. Insects of Micronesia 6: 231-344.

Lister, J.J. (1889). On the Natural History of Christmas Island in the Indian Ocean. Proceedings of the Zoological Society, London 56: 512-531.

Liu, Z., Ślipinski, A. and Pang, H. (2015). Notes on Australian Laius Guérin-Méneville, Dicranolaius Champion and Intybia Pascoe with description of new species related to Dicranolaius c-purpureus (Lea) (Coleoptera: Melyridae: Malachiinae). Zootaxa 3936: 272-280.

Löcker, B., Fletcher, M.J., Lariviere, M.-C. and Gurr, G.M. (2006). The Australian Pentastirini (Hemiptera: Fulgoromorpha: Cixiidae). Zootaxa 1290: 1-138.

Loehle, C. and Eschenbach, W. (2012). Historical bird and terrestrial mammal extinction rates and causes. Diversity and Distributions 18: 84-91.

Lunney, D., Law, B., Schulz, M. and Pennay, M. (2011). Turning the spotlight onto the conservation of Australian bats and the extinction of the Christmas Island Pipistrelle. In: B. Law, P. Eby, D. Lunney and L. Lumsden (eds). The biology and conservation of Australasian bats. pp. 485-498. Royal Zoological Society of NSW, Mosman.

Lyneborg, L. and Barkemeyer, W. (2005). The genus Syritta. A world revision of the genus Syritta Le Peletier and Serville, 1828 (Diptera: Syrphidae). Entomonograph 15: 1-224.

Malipatil, M.B. (2010). Review and revision of Nysius Dallas of Australia and South West Pacific (Hemiptera: Heteroptera: Orsillidae). Zootaxa 2410: 29-44.

Maple, D.J., Barr, R. and Smith, M.J. (2012). A new record of the Christmas Island Blind Snake, Ramphotyphlops exocoeti (Reptilia: Squamata: Typhlopidae). Records of the Western Australian Museum 156: 160. 
Marsh, L. (2000). Echinoderms of Christmas Island. Records of the Western Australian Museum. Supplement 59: 97-101.

Marsh, L. and Fromont, J. (2000). Porifera and Brachipoda of Christmas Island. Records of the Western Australian Museum. Supplement 59: 127.

Martin, T.G., Nally, S., Burbidge, A.A., Arnall, S., Garnett, S.T., Hayward, M.W., Lumsden, L.F., Menkhorst, P., McDonaldMadden, E. and Possingham, H.P. (2012). Acting fast helps avoid extinction. Conservation Letters 5: 274-280.

Matile, L. (1990). Recherches sur la systématique et l'évolution des Keroplatidae (Diptera, Mycetophiloidea). Mémoires du Muséum National d'Histoire Naturelle Paris Sér A, Zoologie 148: 1-654.

McCarthy, P.M. (2001a). The genus Lithothelium (Pyrenulaceae) in Christmas Island, Indian Ocean. Australasian Lichenology 49: 7-9.

McCarthy, P.M. (2001b). The lichen genus Strigula in Christmas Island, Indian Ocean. Bibliotheca Lichenologica 78: 275-287.

McCarthy, P.M. (2001c). The Trichotheliaceae of Christmas Island, Indian Ocean. Lichenologist 33: 393-401.

McCarthy, P.M. (2018). Checklist of the Lichens of Australia and its Island Territories. Version 17 May 2018. Australian Biological Resources Study: Canberra.

McCarthy, P.M. and Elix, J.A. (2002). Additional lichen records from Australia 48. Miscellaneous taxa in Christmas Island. Australasian Lichenology 50: 10-22.

McCreless, E.E., Huff, D.D., Croll, D.A., Tershy, B.R., Spatz, D.R., Holmes, N.D., Butchart, S.H. and Wilcox, C. (2016). Past and estimated future impact of invasive alien mammals on insular threatened vertebrate populations. Nature Communications 7: 12488

Medina, F.M., Bonnaud, E., Vidal, E., Tershy, B.R., Zavaleta, E.S., Donlan, J.C., Keitt, B.S., Corre, M., Horwath, S.V. and Nogales, M. (2011). A global review of the impacts of invasive cats on island endangered vertebrates. Global Change Biology 17: 3503-3510.

Mendoza, J.C.E., Lasley, R.M. and Ng, O.K.L. (2014). New rock crab records (Crustacea: Brachyura: Xanthidae) from Christmas and Cocos (Keeling) Islands, eastern Indian Ocean. Raffles Bulletin of Zoology. Supplement 30: 274-300.

Mendoza, J.C.E. and Ng, P.K.L. (2017). Harryplax severus, a new genus and species of an unusual coral rubble-inhabiting crab from Guam (Crustacea, Brachyura, Christmaplacidae). ZooKeys 647: 23-35.

Merino, S., Hennicke, J., Martínez, J., Ludynia, K., Torres, R., Work, T.M., Stroud, S., Masello, J.F. and Quillfeldt, P. (2012). Infection by Haemoproteus parasites in four species of frigatebirds and the description of a new species of Haemoproteus (Haemosporida: Haemoproteidae). Journal of Parasitology 98: 388-397.

Mesibov, R. (2010). Backgrounder on Christmas Island millipedes.

Mesibov, R. (2018). Millipedes of Australia. https://www. polydesmida.info/millipedesofaustralia/index.html

Mihalca, A.D., Gherman, C.M. and Cozma, V. (2011). Coendangered hard-ticks: threatened or threatening? Parasites and Vectors 4: 71.

Mills, K. (2009). The vegetation of Phillip Island, Norfolk Island group. Envirofund, Norfolk Island.

Mineo, G. and Szabó, J.B. (1978). On the species of Mantibaria seefelderiana (De Stefani-Perez, 1891) (Hymenoptera, Scelionidae). Annales Historico-Naturales Musei Nationalis Hungarici 70: 303-305.
Monte, C., Zilioli, M. and Bartolozzi, L. (2016). Revision of the Australian species of Figulus MacLeay, 1819 (Coleoptera: Lucanidae). Zootaxa, 4189.

Moore, J., Gibson, R. and Jones, H.D. (2001). Terrestrial nemerteans thirty years on. Hydrobiologia 456: 1-6.

Morgan, G.J. (2000). Decapod Crustacea of Christmas Island. Records of the Western Australian Museum. Supplement 59: 117-123.

Morris-Pocock, J.A., Hennicke, J.C. and Friesen, V.L. (2012). Effects of long-term isolation on genetic variation and within-island population genetic structure in Christmas Island (Indian Ocean) seabirds. Conservation Genetics 13: 1469-1481.

Morris, K., Algar, D., Armstrong, D., Ball, D., Bryant, S.L., Canty, P., Copley, P.B., Dickman, C., Fisher, A., Gillespie, G.R., Johnston, M. and Kelly, D. (2018). Values of islands across Australia's states and territories. In: Moro, D. Ball, D. and Bryant, S. (eds). Australian island arks: conservation, management and opportunities. pp. 11-43. CSIRO Publishing: Melbourne.

Moulds, M.S. and Lachlan, R.B. (1987). The butterflies (Lepidoptera) of Christmas Island, Indian Ocean. The Australian Entomologist 14: 57-66.

Murray, J. (1900). Introductory Note. In: Andrews, C.W. (ed). A monograph of Christmas Island (Indian Ocean) - physical features and geology, with descriptions of the fauna and flora by numerous contributors. pp. ix- $\mathrm{x}$. British Museum Trustees: London.

Murray, M.D., Palma, R.L. and Pilgrim, R.L.C. (1990). Ectoparasites of Australian, New Zealand and Antarctic Birds. In: Marchant, S. and Higgins, P.J. (eds). Handbook of Australian, New Zealand and Antarctic Birds Vol. 1, Ratites to Ducks. pp. 1365-1374. Oxford University Press: Melbourne.

Namiotko, T., Wouters, K., Danielopol, D.L. and Humphreys, W.F. (2004). On the origin and evolution of a new anchialine stygobitic Microceratina species (Crustacea, Ostracoda) from Christmas Island (Indian Ocean). Journal of Micropalaeontology 23: 49-59.

Naruse, T. and Ng, P.K.L. (2014). A new family, genus and species of cavernicolous crab (Crustacea: Decapoda: Brachura: Pseudozioidea) from Christmas Island, Australia. Raffles Bulletin of Zoology Supplement 30: 263-273.

Neumann, G., O'Dowd, D.J. and Green, P.T. (2013). Host specificity testing of Tachardiaephagus somervillei (Hymenoptera: 2 Encyrtidae), a biological control agent for the yellow lac scale 3 Tachardina aurantiaca (Hemiptera: Kerriidae). Report to Parks Australia. Melbourne.

Neumann, G., O’Dowd, D.J. and Green, P.T. (2018). Host specificity of an encyrtid parasitoid: historical records and field-based tests in the native region to predict introduction risk. Biological Control 121: 66-73.

Neumann, G., O’Dowd, D.J., Gullan, P.J. and Green, P.T. (2016). Diversity, endemism and origins of scale insects on a tropical oceanic island: Implications for management of an invasive ant. Journal of Asia-Pacific Entomology 19: 159-166.

Neumann, L.G. (1904). Notes sur les Ixodides II. Archives de Parasitologie 8: 444-464

Neuweger, D., White, P. and Ponder, W.F. (2001). Land snails from Norfolk Island sites. Records of the Australian Museum. Supplement 27: 115-122

New, T.R. (1991). Neuroptera from Christmas Island, Indian Ocean. Neuroptera International 6: 133-136. 
New, T.R. (1995). The order Zoraptera (Insecta) from Christmas Island, Indian Ocean. Invertebrate Taxonomy 9: 243-246.

Ng, P.K.L. (2002). On a new species of cavernicolous Neolimera (Crustacea: Decapoda: Brachyura: Xanthidae) from Christmas Island and Ryukyus, Japan. The Raffles Bulletin of Zoology 50: 95-99.

Ng, P.K.L. and Davie, P.J.F. (2012). The Blue Crab of Christmas Island, Discoplax celeste, new species (Crustacea: Decapoda: Brachyura: Gecarcinidae). The Raffles Bulletin of Zoology 60: 89-100.

Ng, P.K.L. and Naruse, T. (2014). The lobsters of Christmas Island and Cocos (Keeling) Islands, with new records of Palinurellus wieneckii (De Man, 1881) and Enoplometopus voigtmanni Türkay, 1989 (Crustacea: Decapoda: Palinuridae, Scyllaridae, Enoplometopidae). The Raffles Bulletin of Zoology. Supplement 30: 305-312.

Nguyen Duy-Jacquemin, M. (2014). Two new species of Lophoturus (Diplopoda, Penicillata, Lophoproctidae) from caves in Christmas Island, Australia, including the second troglomorph in Penicillata. Zoosystema 36: 29-39.

Norman, J.A., Christidis, L., Westerman, M. and Hill, F.A.R. (1998). Molecular data confirms the species status of the Christmas Island Hawk-Owl Ninox natalis. Ети 98: 197-208.

O'Dowd, D.J. and Lake, P.S. (1991). Red crabs in rain forests, Christmas Island: removal and fate of fruits and seeds. Journal of Tropical Ecology 7: 113-122.

Ohlsen, D.J., Perrie, L.R., Shepherd, L.D. and Bayly, M.J. (2015). Taxonomic status and distribution of the critically endangered Christmas Island spleenwort (Asplenium listeri, Aspleniaceae): it is not as rare as we thought. Australian Systematic Botany 27: 372-377.

Oliver, P.M., Blom, M.P.K., Cogger, H.G., Fisher, R.N., Richmond, J.Q. and Woinarski, J.C.Z. (2018). Insular biogeographic origins and high phylogenetic distinctiveness of the recently depleted lizard fauna of Christmas Island, Australia. Biology Letters 14: 20170696.

Olson, S.L. and Warheit, K.I. (1988). A new genus for Sula abbotti. Bulletin of the British Ornithological Club 108: 9-12.

Orchard, M. (2012). Crabs of Christmas Island. Christmas Island Natural History Association: Christmas Island.

Orthoptera Species File (2018). Orthoptera Species File version 5.0. http://orthoptera.speciesfile.org/common/basic/Taxa. aspx?TaxonNameID=1103331

Osawa, M. (2014). Porcellanidae (Crustacea: Decapoda: Anomura) from Christmas and Cocos (Keeling) Islands. Raffles Bulletin of Zoology. Supplement 30: 255-262.

Page, T.J., Hughes, J.M., Real, K.M., Stevens, M.I., King, R.A. and Humphreys, W.F. (2018). Allegory of a cave crustacean: systematic and biogeographic reality of Halosbaena (Peracarida: Thermosbaenacea) sought with molecular data at multiple scales. Marine Biodiversity 48: 1185-1202.

Parent, O. (1935). Dipteres dolichopodides nouveaux. Encyclopédie Entomologiue (B) II 8: 59-96.

Patterson, S.A., Morris-Pocock, J.A. and Friesen, V.L. (2011). A multilocus phylogeny of the Sulidae (Aves: Pelecaniformes). Molecular Phylogenetics and Evolution 58: 181-191.

Pendlebury, H.M. (1933). On a small collection of butterlies from Christmas Island, Indian Ocean. Bulletin of the Raffles Museum 8: 94-97.

Pendlebury, H.M. (1947). Lepidoptera (Heterocera). Bulletin of the Raffles Museum 18: 58-73.
Peters, J.L. (1940). Check-list of the Birds of the World. Volume 4. Harvard University Press: Cambridge, Massachusetts, USA.

Peveling, R., McWilliam, A.N., Nagel, P., Rasolomanana, H., Rakotomianina, L., Ravoninjatovo, A., Dewhurst, C.F., Gibson, G., Rafanomezana, S. and Tingle, C.C.D. (2003). Impact of locust control on harvester termites and endemic vertebrate predators in Madagascar. Journal of Applied Ecology 40: 729-741.

Phalen, D.N., Hall, J., Ganesh, G., Hartigan, A., Smith, C., De Jong, C., Field, H. and Rose, K. (2017). Genetic diversity and phylogeny of the Christmas Island flying fox (Pteropus melanotus natalis). Journal of Mammalogy 98: 428-437.

Pickering, J. and Norris, C.A. (1996). New evidence on the extinction of the endemic murid Rattus macleari from Christmas Island, Indian Ocean. Australian Mammalogy 19: $35-41$.

Pocock, R.I. (1887). Report on a zoological collection made by the officers of H.M.S. "Flying Fish" at Christmas Island, Indian Ocean. V. Crustacea. Proceedings of the Zoological Society London 1887: 520.

Pocock, R.I. (1889). On the Arachnida, Myriopoda, and Land-Crustacea of Christmas Island. Proceedings of the Zoological Society London 56: 556-564.

Pocock, R.I. (1900). Chilopoda, Diplopoda, and Arachnida. In: Andrews, C.W. (ed). A monograph of Christmas Island (Indian Ocean). pp. 153-162. British Museum Trustees: London.

Poore, G.C.B. and Humphreys, W.F. (1992). First record of Thermosbaenacea (Crustacea) from the Southern Hemisphere: a new species from a cave in tropical Western Australia. Invertebrate Taxonomy 6: 719-725.

Prout, L.B. (1920). New Geometridae. Novitates Zoologicae 27: 265-312.

Prout, L.B. (1933). The Geometridae of Christmas Island, Indian Ocean. Bulletin of the Raffles Museum 8: 88-94.

Régnier, C., Achaz, G., Lambert, A., Cowie, R.H., Bouchet, P. and Fontaine, B. (2015a). Mass extinction in poorly known taxa. Proceedings of the National Academy of Sciences 112: 7761-7766.

Régnier, C., Bouchet, P., Hayes, K.A.,Yeung, N.W., Christensen, C.C., Chung, D.J.D., Fontaine, B. and Cowie, R.H. (2015b). Extinction in a hyperdiverse endemic Hawaiian land snail family and implications for the underestimation of invertebrate extinction. Conservation Biology 29: 17151723.

Régnier, C., Fontaine, B. and Bouchet, P. (2009). Not knowing, not recording, not listing: numerous unnoticed mollusk extinctions. Conservation Biology 23: 1214-1221.

Reid, D.A. (1969). A list of fungi collected from Christmas Island (Indian Ocean) by D.A. Powell, 1968. Unpublished report.

Reid, D.A. (1986). New or interesting records of Australasian Basidiomycetes: VI. Transactions of the British Mycological Society 86: 429-440.

Rheindt, F.E., Christidis, L., Norman, J.A., Eaton, J.A., Sadanandan, K.R. and Schodde, R. (2017). Speciation in Indo-Pacific swiftlets (Aves: Apodidae): integrating molecular and phenotypic data for a new provisional taxonomy of the Collocalia esculenta complex. Zootaxa 4250: 401-433.

Richards, O.W. (1978). The Australian social wasps (Hymenoptera: Vespidae). Australian Journal of Zoology Supplementary Series 26: 1-132. 
Richards, Z.T. and Hobbs, J.-P.A. (2014). The status of hard coral diversity at Christmas Island and Cocos (Keeling) Islands. Raffles Bulletin of Zoology. Supplement 30: 376398.

Ridley, H.N. (1891). A day at Christmas Island. Journal of the Straits Branch of the Royal Asiatic Society 23: 123-139.

Ridley, H.N. (1906a). The botany of Christmas Island. Journal of the Straits Branch of the Royal Asiatic Society 45: 156-271.

Ridley, H.N. (1906b). An expedition to Christmas Island. Journal of the Straits Branch of the Royal Asiatic Society 45: $137-155$.

Rosa, D. (1898). On some new earthworms in the British Museum. Annals and Magazine of Natural History 7: 277-290.

Rose, K., Agius, J., Hall, J., Thompson, P., Eden, J.-S., Srivastava, M., Tiernan, B., Jenkins, C. and Phalen, D. (2017). Emergent multisystemic Enterococcus infection threatens endangered Christmas Island reptile populations. PLOS ONE 12: e0181240.

Rossetti, G., Pinto, R.L. and Martens, K. (2011). Description of a new genus and two new species of Darwinulidae (Crustacea, Ostracoda), from Christmas Island (Indian Ocean) with some considerations on the morphological evolution of ancient asexuals. Belgian Journal of Zoology 141: $55-74$.

Roth, L.M. (1999). New cockroach species, redescriptions, and records, mostly from Australia, and a description of Metanocticola christmasensis gen. nov. sp. nov. from Christmas Island (Blattaria). Records of the Western Australian Museum 19: 327-364.

Roth, L.M. (2000). The cockroaches (Blattaria) of Christmas Island (Indian Ocean). Oriental Insects 34: 67-76.

Rudolf, E. and Brock, P. (2017). Ramulus stilpnoides. http:// www.iucnredlist.org/details/80168415/0

Savory, T.H. (1943). On a Collection of Arachnida from Christmas Island. Annals and Magazine of Natural History 10: $355-360$.

Savory, T.H. (1947). Arachnida. Bulletin of the Raffles Museum 18: $53-55$.

Sax, D.F. and Gaines, S.D. (2008). Species invasions and extinction: the future of native biodiversity on islands. Proceedings of the National Academy of Sciences 105: 11490-11497.

Schawaller, W. (2006). Revision of the Oriental species of the genus Bradymerus Perroud, with descriptions of 29 new species (Coleoptera: Tenebrionidae). Stuttgarter Beiträge zur Naturkunde Serie A (Biologie) 694: 1-64.

Schulz, M. (2004). National Recovery Plan for the Christmas Island Shrew Crocidura attenuata trichura. Department of the Environment and Heritage: Canberra.

Schulz, M. and Lumsden, L.F. (2004). National Recovery Plan for the Christmas Island Pipistrelle Pipistrellus murrayi. Department of the Environment and Heritage: Canberra.

Schwarzhans, W. and Møller, P.R. (2011). New Dinematichthyini (Teleostei: Bythitidae) from the Indo-west Pacific, with the description of a new genus and five new species. The Beagle 27: 161-177.

Schwarzhans, W. and Nielsen, J.G. (2011). Revision of the genus Microbrotula (Teleostei: Bythitidae), with description of two new species and a related new genus. The Beagle: Records of the Museums and Art Galleries of the Northern Territory 27: 147-160.
Ševčík, J. and Papp, L. (2011). New Afrotropical and Oriental species of Micrepimera Matile (Diptera: Keroplatidae). Zootaxa 3128: 58-66.

Sharpe, R.B. (1887). Report on a zoological collection made by the officers of H.M.S. "Flying Fish" at Christmas Island, Indian Ocean. II. Birds. Proceedings of the Zoological Society London 1887: 515-516.

Sharpe, R.B. (1900). Aves. In: Andrews, C.W. (ed). A monograph of Christmas Island (Indian Ocean). pp. 37-50. British Museum Trustees: London.

Shen, C.-J. (1936). Notes on the family Haplocarcinidae (CoralInfesting Crabs) with descriptions of two new species. Hong Kong Naturalist Supplement 5: 21-26.

Shivas, R.G. and Hilton, R.N. (1990). Collections of fungi from Christmas Island, Indian Ocean. Kingia 1: 295-301.

Sierwald, P. and Spelda, J. (2018). MilliBase. http://www. millibase.org

Sihvonen, P. (2005). Check-list of Chinese Scopula Schrank species and an analysis of species diversity (Lepidoptera: Geometridae: Sterrhinae). Journal of Asia-Pacific Entomology 8: 29-36.

Slipinski, A. and Escalona, H. (2016). Australian Longhorn Beetles (Coleoptera: Cerambycidae) Volume 2: Subfamily Cerambycinae. CSIRO Publishing: Melbourne.

Smith, E.A. (1889). On the terrestrial molluscs of Christmas Island. Proceedings of the Zoological Society London 56: 536-538.

Smith, M.A. (1929). Description of a new skink from Christmas island and a new frog from Annam. Annals and Magazine of Natural History 10: 294-297.

Smith, M.J., Cogger, H., Tiernan, B., Maple, D., Boland, C., Napier, F., Detto, T. and Smith, P. (2012). An oceanic island reptile community under threat: the decline of reptiles on Christmas Island, Indian Ocean. Herpetological Conservation and Biology 7: 206-218.

Smithers, C.N. (1995). Psocoptera (Insecta) of Christmas Island. Invertebrate Systematics 9: 529-561.

Souza-Gonçalves, I., Lopes-Andrade, C., SandovalGómez, V.E. and Lawrence, J.F. (2019). The Australian Paratrichapus Scott (Coleoptera: Ciidae). Insect Systematics and Evolution. 50: 679-701.

Stebnicka, Z. (1994). A new genus of unusually modified Psammodiini from Christmas Island [Coleoptera: Scarabaeoidea: Aphodiinae]. Acta Zoologica Cracoviensia 37: $65-69$.

Stebnicka, Z.T. and Howden, H.F. (1996). Australian genera and species in the tribes Odontolochini, Psammodiini, Rhyparini, Stereomerini and part of the Eupariini (Coleoptera: Scarabaeoidea: Aphodiinae). Invertebrate Systematics 10: 97-170.

Steinmann, H. (1989). World catalogue of Dermaptera. Kluwer Academic Publishers: Dordrecht.

Stokes, T. (1988). A review of the birds of Christmas Island, Indian Ocean. Occasional paper no. 16. Australian National Parks and Wildlife Service, Canberra.

Stokes, T., Sheils, W. and Dunn, K. (1984). Birds of the Cocos (Keeling) Islands, Indian Ocean. Ети 84: 23-28.

Stork, N.E., Kitching, R.L., Davis, N.E. and Abbott, K.L. (2014). The impact of aerial baiting for control of the yellow crazy ant, Anoplolepis gracilipes, on canopy-dwelling arthropods and selected vertebrates on Christmas Island (Indian Ocean). Raffles Bulletin of Zoology. Supplement 30: 81-92. 
Streimann, H. and Curnow, J. (1989). Catalogue of mosses of Australia and its external territories. Australian flora and fauna series number 10. Australian Biological Resources Study: Canberra.

Surman, C.A. (2004). A review and assessment of the status of arthropods from Christmas Island, Indian Ocean. Report to Parks Australia North. Perth.

Tan, H.H., Orchard, M., Davie, P.J.F. and Ng, P.K.L. (2014a). Christmas Island and Cocos (Keeling) Islands: biodiversity and management challenges. Raffles Bulletin of Zoology. Supplement 30: 1-468.

Tan, H.H., Tohru, N., Yoshihisa, F. and Tan, S.K. (2014b). Observations on the fauna from submarine and associated anchialine caves in Christmas Island, Indian Ocean Territory, Australia. Raffles Bulletin of Zoology. Supplement 30: $406-418$.

Tan, S.K. and Low, M.E.Y. (2014). Checklist of the Mollusca of Cocos (Keeling)/Christmas Island ecoregion. Raffles Bulletin of Zoology. Supplement 30: 313-375.

Tershy, B.R., Shen, K.-W., Newton, K.M., Holmes, N.D. and Croll, D.A. (2015). The importance of islands for the protection of biological and linguistic diversity. Bioscience 65: 592-597.

Thierry-Mieg, P. (1915). Descriptions de Lépidoptères nouveaux. Miscellanea Entomologica 23: 323.

Thomas, O. (1887). Report on a zoological collection made by the officers of H.M.S. "Flying Fish" at Christmas Island, Indian Ocean. I. Mammalia. Proceedings of the Zoological Society London 1887: 511-514.

Thomas, O. (1889). On the mammals of Christmas Island. Proceedings of the Zoological Society London 56: 532-534.

Thompson, F.C. (2014). Flower flies (Diptera: Syrphidae) of Christmas Island, Indian Ocean. Australian Entomologist 41: $129-134$.

Tirtaningtyas, F.N. and Hennicke, J.C. (2015). Threats to the critically endangered Christmas Island Frigatebird Fregata andrewsi in Jakarta Bay, Indonesia, and implications for reconsidering conservation priorities. Marine Ornithology 43: $137-140$.

Trueman, N.A. (1965). The phosphate, volcanic and carbonate rocks of Christmas Island (Indian Ocean). Journal of the Geological Society of Australia 12: 261-283.

Tweedie, M.W.F. (1933). Some insects from Christmas Island, Indian Ocean. Bulletin of the Raffles Museum 8: 98-100.

Tweedie, M.W.F. (1947). On the Brachyura of Christmas Island. Bulletin of the Raffles Museum 18: 27-42.

Tweedie, M.W.F. (1950). The fauna of the Cocos-Keeling Islands. Brachyura and Stomatopoda. Bulletin of the Raffles Museum 22: 105-148.

Van der Sluijs, J.P., Amaral-Rogers, V., Belzunces, L.P., Bijleveld van Lexmond, M.F.I.J., Bonmatin, J., Chagnon, M., Downs, C.A., Furlan, L., Gibbons, D.W., Giorio, C., Girolami, V., Foulson, D., Kreutzweiser, D.P., Krupke, C., Liess, M., Long, E., McGField, M., Mineau, P., Mitchell, E.A.D., Morrissey, C.A., Noome, D.A., Pisa, L., Settele, J., Simon-Delso, N.,Stark, J.D., Tapparo, A., Van Dyck, H., van Praagh, J., Whitehorn, P.R. and Wiemers, M. (2015). Conclusions of the Worldwide Integrated Assessment on the risks of neonicotinoids and fipronil to biodiversity and ecosystem functioning. Environmental Science Pollution Research 22: 148-154.

van der Wulp, F.M. (1872). Bijdrage tot de kennis der Asiliden van den Oost Indischen Archipel. Tijdschrift voor Entomologie 15: 129-279.
Van Soest, R.W.M., Boury-Esnault, N., Hooper, J.N.A., Rützler, K., de Voogd, N.J., Alvarez, B., Hajdu, E., Pisera, A.B., Manconi, R., Schönberg, C., Klautau, M., Picton, B., Kelly, M., Vacelet, J., Dohrmann, M., Díaz, M.-C., Cárdenas, P., Carballo, J.L., Ríos, P. and Downey, R. (2018). World Porifera database. Haliclona irregularis (Kirkpatrick, 1900). http://www.marinespecies.org/porifera/porifera. php? $\mathrm{p}=$ taxdetailsandid $=184519$ [accessed August 2018

Waldock, J.M. and Lewis, J.G.E. (2014). Recent collections of centipedes from Christmas Island (Myriapoda: Chilopoda). Raffles Bulletin of Zoology Supplement 30: 71-80.

Walker, K.L. (1997). Supplement to a revision of Australian members of the bee genus Homalictus (Cockerell) (Hymenoptera: Halictidae). Memoirs of the National Museum Victoria 56: 69-82.

Walsh, J.C., Watson, J.E.M., Bottrill, M.C., Joseph, L.N. and Possingham, H.P. (2012). Trends and biases in the listing and recovery planning for threatened species: an Australian case study. Oryx 47: 131-143.

Walsingham, T.d.G. (1900). Micro-Lepidoptera. In: Andrews, C.W. (ed). A monograph of Christmas Island (Indian Ocean). pp. 75-80. British Museum Trustees: London.

Ward, M. (1934). Notes on a collection of crabs from Christmas Island, Indian Ocean. Bulletin of the Raffles Museum 9: 5-28.

Warren, W. (1905). New species of Thyrididae, Uraniidae, and Geometridae, from the oriental region. Novitates Zoologicae 12: 6-73.

Waterhouse, C.O. (1887). Report on a zoological collection made by the officers of H.M.S. "Flying Fish" at Christmas Island, Indian Ocean. VI. Coleoptera. Proceedings of the Zoological Society London 1887: 520-521.

Waterhouse, C.O., Gahan, C.J. and Arrow, G.J. (1900). Coleoptera. In: Andrews, C.W. (ed). A monograph of Christmas Island (Indian Ocean). pp. 89-127. British Museum Trustees: London.

Weeks, A. (2013). Assessing the non-target impacts and bioaccumulation of the Anoplolepis gracilipes aerial baiting program on Christmas Island. Report for The Director of National Parks. Melbourne.

Weeks, A. and McColl, S. (2011). Monitoring of the 2009 aerial baiting of yellow crazy ants (Anoplolepis gracilipes) on non-target invertebrate fauna on Christmas Island. Report for The Director of National Parks. Melbourne.

Wells, F.E., Bryce, C.W., Clark, J.E. and Hansen, G.M. (1990). Christmas shells: The marine molluscs of Christmas Island (Indian Ocean). Christmas Island Natural History Association: Christmas Island.

Wells, F.E. and Slack-Smith, S.M. (2000). Molluscs of Christmas Island. Records of the Western Australian Museum. Supplement 59: 103-115.

Whittaker, R.J., Triantis, K.A. and Ladle, R.J. (2008). A general dynamic theory of oceanic island biogeography. Journal of Biogeography 35: 977-994.

Woinarski, J. (2018). A bat's end: the Christmas Island pipistrelle and extinction in Australia. CSIRO Publishing: Melbourne.

Woinarski, J.C.Z., Burbidge, A.A. and Reside, A. (2018). Enhancing island conservation outcomes: the policy and legal context, need, and options. In: Moro, D. Ball, D. and Bryant, S. (eds). Australian island arks: conservation management and opportunities. pp. 45-59. CSIRO Publishing: Clayton. 
Woinarski, J.C.Z., Detto, T. and MacRae, I. (2014). The other subpopulation of Christmas Island White-eye Zosterops natalis: a historic introduction has led to an enduring subpopulation on Horsburgh Island, Cocos (Keeling) islands group. Raffles Bulletin of Zoology Supplement 30: $65-70$.

Woinarski, J.C.Z., Garnett, S.T., Legge, S.M. and Lindenmayer, D.B. (2017). The contribution of policy, law, management, research, and advocacy failings to the recent extinctions of three Australian vertebrate species. Conservation Biology 31: 13-23.

Wood Jones, F. (1909). Fauna of the Cocos-Keeling Atoll. Proceedings of the Zoological Society of London 1909: $132-159$.
Wyatt, K.B., Campos, P.F., Gilbert, M.T.P., Kolokotronis, S.-O., Hynes, W.H., DeSalle, R., Daszak, P., MacPhee, R.D.E. and Greenwood, A.D. (2008). Historic mammal extinction on Christmas Island (Indian Ocean) correlates with introduced infectious disease. PLOS ONE 3: e3602.

Yata, O. (1995). A revision of the Old World species of the genus Eurema Hiibner (Lepidoptera, Pieridae). Part V. Description of the hecabe group. Bulletin of the Kitakyushu Museum of Natural History 14: 1-4.

Zettel, H. (1990). Neue Phanerotoma - Arten von pazifischen Inseln. (Hym. Bracondiae). Deutsche Entomologische Zeitschrift 37: 45-69.

MANUSCRIPT RECEIVED 2 APRIL 2019; ACCEPTED 18 JULY 2019. 